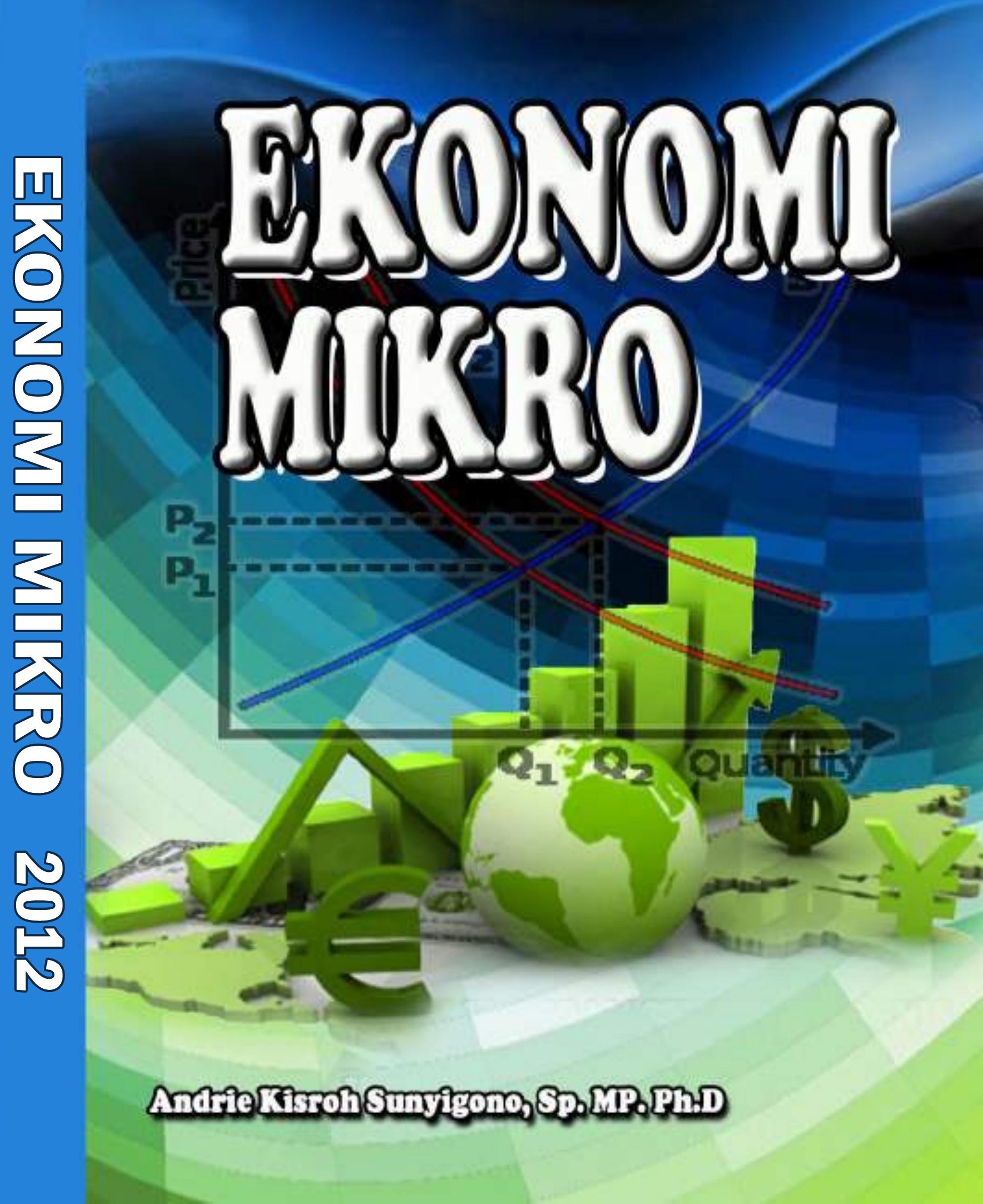


Andrie Kisroh Sunyigono, SP., MP., Ph.D.

\section{EKONOMI MIKRO}

Editor:

Dr. Elys Fauziyah. SP. MP.

Penerbit: 


\section{Sanksi Pelanggaran}

\section{Undang-Undang Nomor 12 Tahun 1997}

Tentang Perubahan atas Undang-Undang Nomor 5 Tahun 1982

Tentang Hak Cipta

Sebagaimana Telah Diubah dengan

Pasal 44

\section{Undang-Undang Nomor 7 Tahun 1987}

1. Barangsiapa dengan sengaja dan tanpa hak mengumumkan atau memperbanyak suatu ciptaan atau memberi izin untuk itu, dipidana dengan pidana penjara paling lama 7 (tujuh) tahun dan/atau denda paling banyak Rp.100.000.000,00 (seratus juta rupiah).

2. Barangsiapa dengan sengaja menyiarkan, memamerkan, mengedarkan, atau menjual kepada umum suatu hak ciptaan atau barang hasill pelanggaran Hak Cipta sebagaimana dimaksudkan dalam Ayat (1), dipidana dengan pidana paling lama 5 (lima) tahun dan/atau denda paling banyak Rp.50.000.000,00 (lima puluh juta rupiah).

\section{EKONOMI MIKRO}

Oleh:

Andrie Kisroh Sunyigono, SP., MP., Ph.D.

Cetakan Pertama, Desember 2012

Hak cipta dilindungi undang undang

Dilarang memperbanyak isi buku ini, baik sebagian maupun seluruhnya, dalam bentuk apa pun tanpa izin tertulis dari Penerbit.

Diterbitkan oleh UTM PRESS

Jl. Raya Telang, PO Box 2 Kamal, Bangkalan - Madura

Telp. (031) 3011146, Fax. (031) 3011506

ISBN $978-602-7998-30=0$

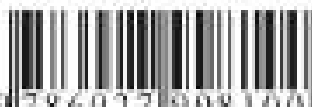




\section{KATA PENGANTAR}

Syukur Alhamdulillah penulis panjatkan kehadirat Allah SWT yang telah memberikan rahmad, taufiq serta hidayah-Nya sehingga pada kesempatan yang berbahagia ini penulis dapat menyelesaikan tulisan yang sangat sederhana ini untuk digunakan sebagai acuan dalam perkuliahan Ekonomi Mikro.

Tulisan ini merupakan ringkasan dari beberapa buku pengantar teori ekonomi mikro. Oleh karena hanya merupakan sebuah ringkasan, sehingga apa yang tercantum di dalamnya hanya merupakan pokokpokok pikiran saja. Apabila kita ingin mendalami lebih jauh maka perlu banyak membaca buku-buku aslinya. Namun jika hanya diperuntukkan sebagai bahan bacaan yang memuat pengantar ilmu ekonomi mikro kiranya tulisan sederhana ini mungkin dapat memberikan manfaat. Pada akhir setiap bab dalam buku ini diberikan beberapa latihan soal yang bertujuan untuk memperdalam pemahaman mahasiswa tentang topic yang dipelajari sehingga tujuan instruksional khusus yang telah ditetapkan bias tercapai.

Akhirnya semoga kontribusi pemikiran yang sederhana ini dapat memberikan sedikit tambahan ilmu pengetahuan dan wawasan bagi para mahasiswa semester-semester awal untuk memahami konsep, teori dan aplikasi dari Ekonomi Mikro.

Bangkalan, November 2012

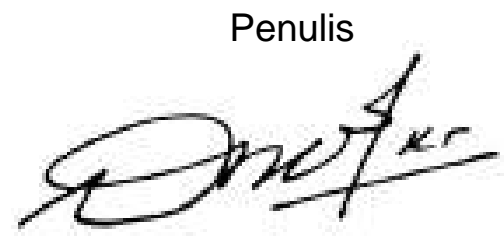

Andrie Kisroh Sunyigono 
iv 


\section{DAFTAR ISI}

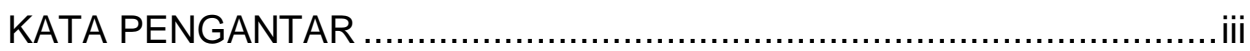

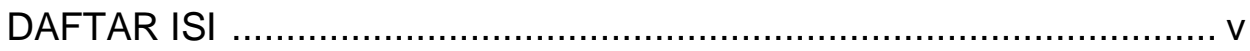

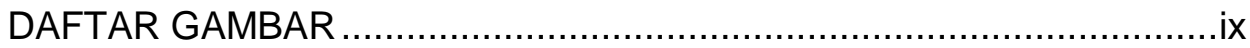

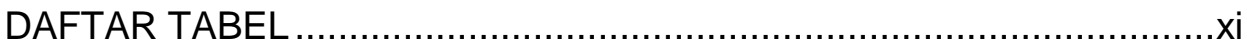

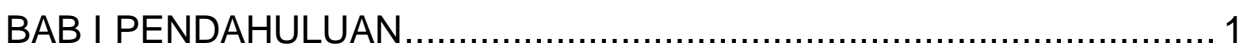

1.1. Definisi dan Tujuan Teori ................................................ 1

1.2. Kelangkaan Ekonomi ........................................................ 2

1.3. Model Ekonomi .................................................................... 2

1.4. Definisi Ilmu Ekonomi .......................................................... 2

1.5. Definisi dan Fungsi Teori Ekonomi Mikro ................................. 3

1.6. Kegiatan Ekonomi.............................................................. 4

1.7. Sumber Daya Ekonomi .................................................... 5

1.8. Hasil Kegiatan Produksi ........................................................ 6

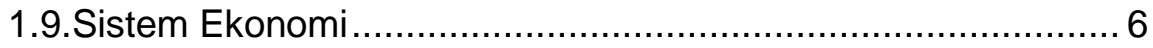

1.10.Aliran Barang, Uang dan Pasar............................................ 7

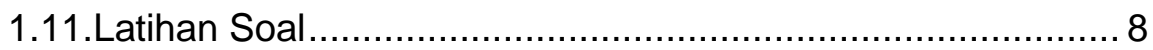

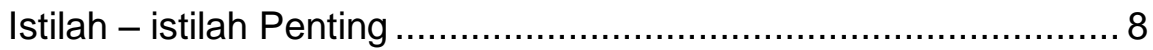

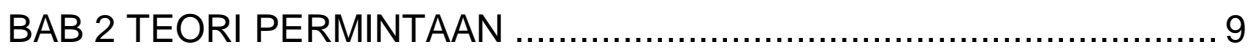

2.1. Fungsi Permintaan ........................................................... 9

2.1.1. Permintaan Individu terhadap Suatu Barang ................ 9

2.1.2. Perubahan Jumlah Barang yang Diminta ................... 12

2.1.3. Perubahan Permintaan ............................................ 13

2.1.4. Permintaan Pasar ....................................................... 14

2.1.5. Barang Inferior, Normal dan Superior......................... 15

2.1.6. Barang Komplementer dan Substitusi ........................ 16

2.2.Teori Perilaku Konsumen.................................................... 18

2.2.1. Teori Utilitas Kardinal ............................................. 18

2.2.2. Teori Kurva Indiferen................................................. 22

2.2.3. Surplus Konsumen.................................................. 36

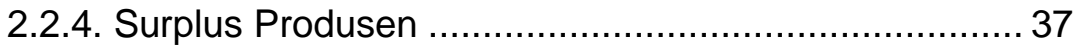

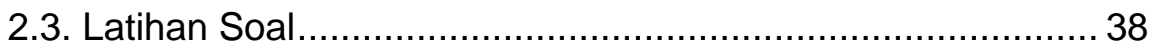

Istilah - istilah Penting ............................................................. 40

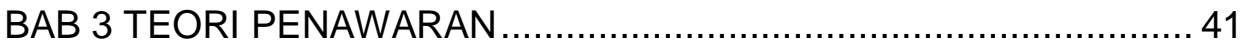

3.1. Penawaran Suatu Barang .................................................. 41

3.2. Penawaran Pasar Suatu Barang .......................................... 43

3.3. Pengaruh Non Harga terhadap Penawaran ......................... 45 


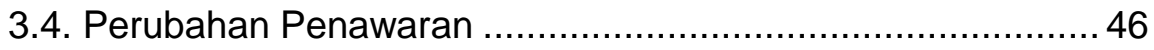

3.5. Perubahan Jumlah yang Ditawarkan.................................... 47

3.6. Latihan Soal .................................................................. 48

Istilah - istilah Penting ; ...................................................... 48

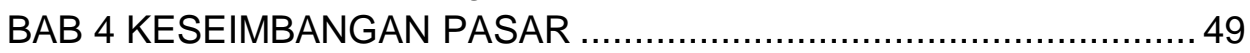

4.1. Arti Keseimbangan Pasar ................................................. 49

4.2. Pergeseran Permintaan atau Penawaran............................. 52

4.3. Kebijakan Harga Dasar dan Harga Maksimum....................... 53

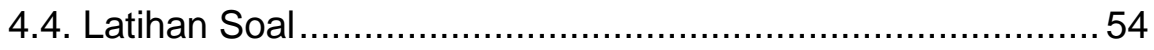

Istilah - istilah Penting ........................................................... 54

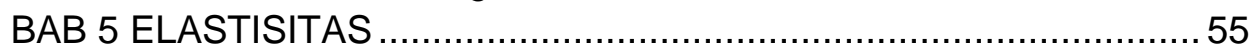

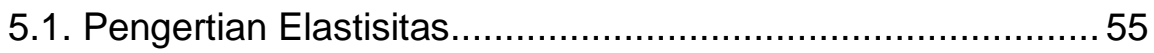

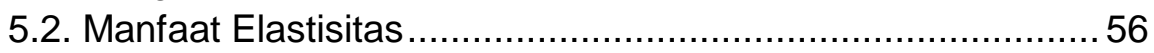

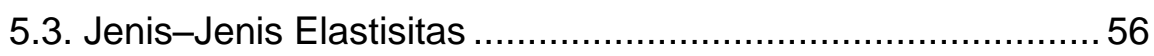

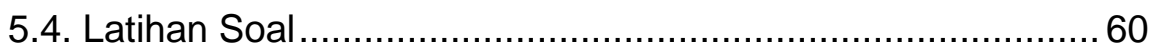

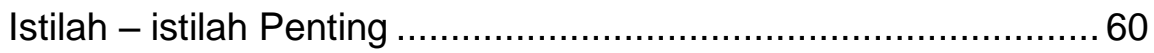

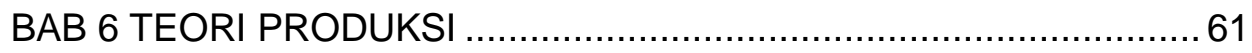

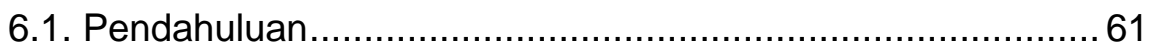

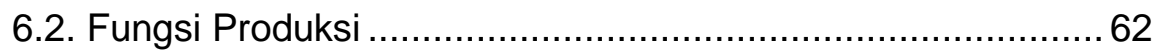

6.3. Produk Total, Produk Rata-rata, dan Produk Marginal ..........63 63

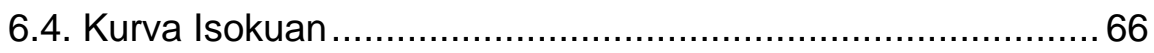

6.5. Hukum Pertambahan yang Semakin Berkurang.................... 71

6.6. Tahap-Tahap Produksi..................................................... 71

6.7. Return to Scale (Skala Keuntungan) ................................... 72

6. 8. Analisis Jangka Pendek dan Jangka Panjang ..................... 72

6. 9.Latihan Soal ..................................................................... 73

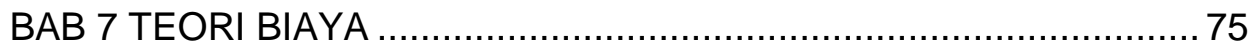

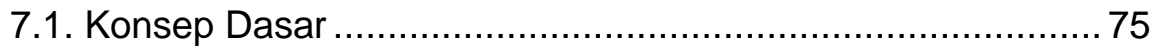

7.2. Biaya Total, Biaya Tetap dan Biaya Variabel ....................... 76

7.3. Biaya Rata-Rata dan Biaya Marginal ................................. 77

7.4. Hubungan Antara Produksi dan Biaya Produksi.................... 79

7.5. Proses Produksi dalam Jangka Panjang dan Biaya .............. 81

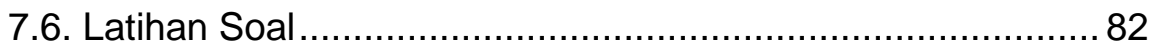

Istilah-istilah Penting ............................................................ 83

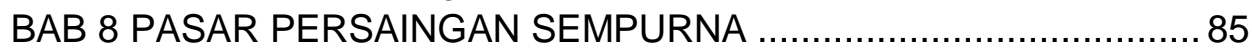

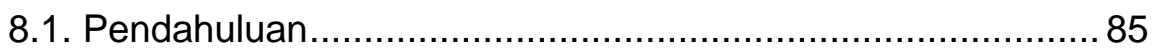

8.2. Perilaku Perusahaan di Pasar Persaingan Sempurna........... 86

8.3. Permintaan di Pasar Persaingan Sempurna ........................ 86

8.4. Hubungan antara Total, Average dan Marginal Revenue ...... 87 
8.5. Maksimisasi Keuntungan .................................................. 88

8.6. Beberapa Kemungkinan Kedudukan Kegiatan Perusahaan.. 89

8.7. Kondisi Pasar Persaingan Sempurna dalam Jangka

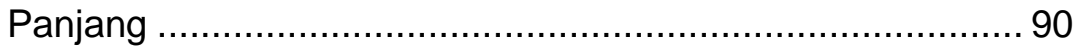

8.8. Kebaikan dan Keburukan Pasar Persaingan Sempurna ....... 91

8.9.Latihan Soal................................................................... 92

Istilah-istilah Penting ........................................................... 93

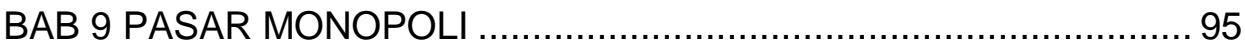

9.1. Pengertian Monopoli ......................................................... 95

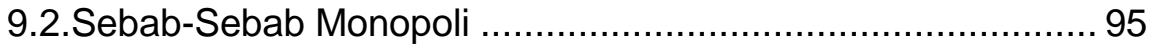

9.3. Maksimisasi Keuntungan ................................................... 97

9.4. Kebijakan Diskriminasi Harga .......................................... 100

9.5. Kurva Penawaran Produsen dalam Pasar Monopoli ........... 101

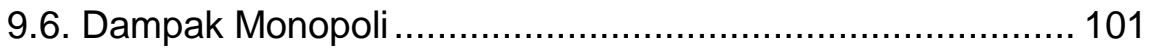

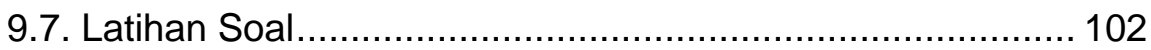

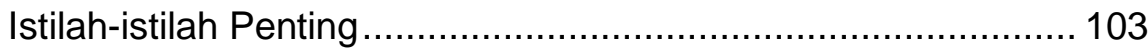

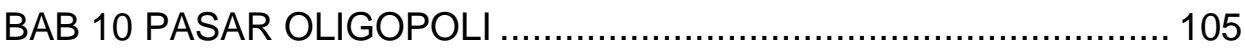

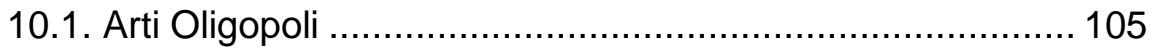

10.2.Output dan Harga dalam Oligopoli .................................... 106

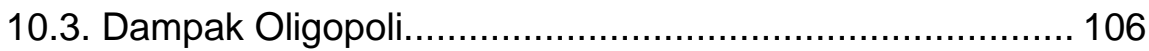

10.4. Model Cournot ................................................................ 107

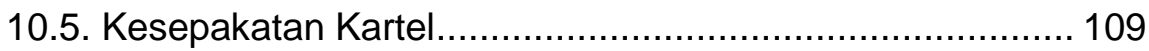

10.6. Latihan Soal................................................................. 110

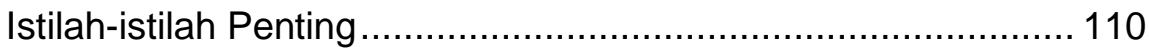

BAB 11 PASAR PERSAINGAN MONOPOLISTIS ............................ 111

11.1. Karakteristik Persaingan Monopolistis.............................. 111

11.2. Keseimbangan dalam Persaingan Monopolistis ................. 113

11.3. Dampak Persaingan Monopolistis .................................... 113

11.4. Latihan Soal............................................................... 114

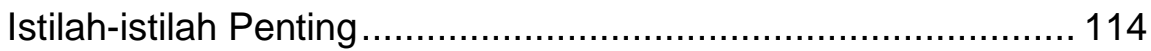

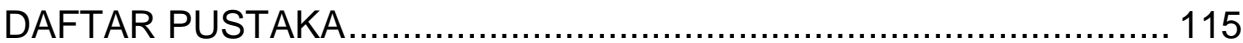


viii 


\section{DAFTAR GAMBAR}

Gambar 1.1. Aliran Uang dan Barang ............................................ 7

Gambar 2.1. Kurva Permintaan Suatu Barang ................................... 11

Gambar 2.2.Perbedaan Jumlah Permintaan dan Jumlah yang Diminta 13

Gambar 2.3. Pergeseran Permintaan pada Barang Normal dan Inferior 15

Gambar 2.4. Perilaku Dua Barang yang Bersifat Substitusi ................. 16

Gambar 2.5. Perilaku Dua Barang yang Bersifat Komplementer........... 17

Gambar 2.6. Kurva Total Utiliti ...................................................... 19

Gambar 2.7. Derivasi Nilai Marginal Utiliti dari Total Utiliti..................... 21

Gambar 2.8. Hubungan antara Marginal Utility, Average Utility dan

Total Utility ................................................................. 21

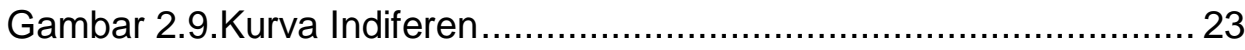

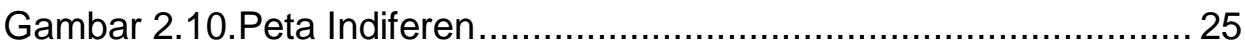

Gambar 2.11.Perpotongan antar Kurva Indiferen................................ 27

Gambar 2.12.Garis anggaran dan pilihan tersedia............................. 28

Gambar 2.13. Perubahan Harga Produk......................................... 29

Gambar 2.14. Perubahan Pendapatan akan Menggeser Garis

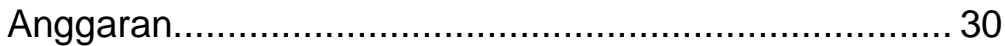

Gambar 2.15. Keseimbangan Konsumen ......................................... 31

Gambar 2.16. Penurunan Harga T (U adalah subsitusi T) ................... 32

Gambar 2.17. Peningkatan Pendapatan ........................................... 33

Gambar 2.18. Makan (U) adalah Barang Normal dan Rumah (T) barang inferior .......................................................... 34

Gambar 2.19.Rumah Produk Inferior atau Normal ............................. 34

Gambar 2.20. Kurva Konsumsi Pendapatan dan Kurva Engel.............. 35

Gambar 2.21. Surplus Konsumen ................................................. 37

Gambar 2.22. Surplus Produsen...................................................... 38

Gambar 3.1. Kurva Penawaran Suatu Barang ................................... 42

Gambar 3.2.Penawaran Perusahaan................................................. 44

Gambar 3.3. Pergeseran Penawaran............................................... 46

Gambar 3.4. Kurva Perubahan Jumlah Penawaran ........................... 47

Gambar 4. 1. Kurva Keseimbangan ................................................ 50

Gambar 4. 2.Posisi Keseimbangan Suatu Penawaran dan Permintaan 51

Gambar 4. 3. Pergeseran Kurva Permintaan ................................... 52

Gambar 4. 4. Pergeseran Permintaan Akibat Faktor Selain Harga ....... 53

Gambar 5. 1. Elastis, Inelastis dan Uniter ........................................ 57

Gambar 6. 1. Skema Sistem Produksi ........................................... 61 
Gambar 6.2.Kurve TP, MP dan AP.

Gambar 6.3 Hubungan Kurva Produk Total dengan Average Product dan

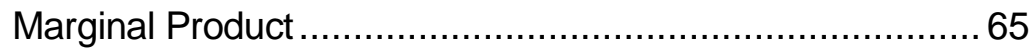

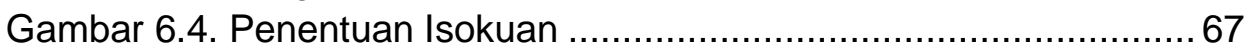

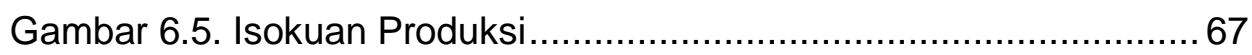

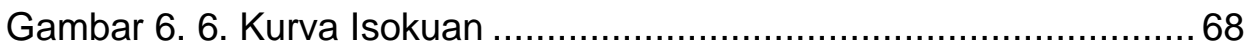

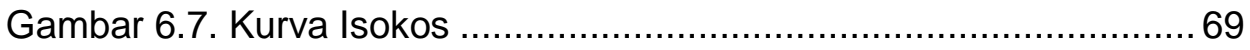

Gambar 6. 8. Peta Isokuan ............................................................. 70

Gambar 6.9.Kurva Keseimbangan isokos dan isokuan ........................70

Gambar 6.10.Kurva Tahapan Produksi ............................................... 71

Gambar 7.1. Kurva Biaya Total, Biaya Variabel dan Biaya Tetap..........77

Gambar 8.1. Kurva Permintaan pada Pasar Persaingan Sempurna .....87

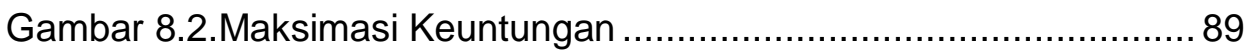

Gambar 9.1. Maksimisasi Keuntungan dari Sebuah Perusahaan pada

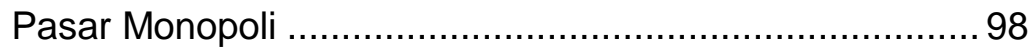

Gambar 9.2.Fungsi Penerimaan dan Biaya untuk Pelaku Monopoli .... 100

Gambar 10.1. Model Cournot.......................................................... 108

Gambar 10.2.Kesepakatan Kartel ................................................ 109

Gambar 11.1. Maksimisasi Keuntungan Jangka Pendek pada Pasar

Persaingan Monopolistis ............................................ 112 


\section{DAFTAR TABEL}

Tabel 2.1. Skedul Permintaan terhadap Suatu Barang X .................... 11

Tabel 2.2. Permintaan Individu dan Permintaan Pasar .......................... 14

Tabel 2.3.Total dan Marginal Utility ................................................... 19

Tabel 3.1. Skedul Penawaran Barang X ........................................... 42

Tabel 3.2.Skedul Penawaran di Suatu Industri..................................... 44

Tabel 3.3. Skedul Penawaran Individual dan Penawaran Pasar ........... 44

Tabel 3.4. Faktor yang Mempengaruhi Penawaran Suatu Barang ........ 45

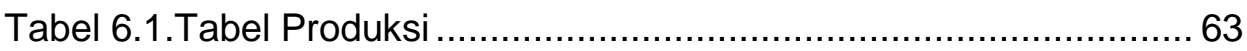

Tabel 7.1. Hubungan antara Output dengan TFC, TVC dan TC........... 77

Tabel 7.2.Hubungan antara FC, VC, TC, AFC, AVC, AC dan MC ......... 78

Tabel 7.3. Hubungan Produksi dan Biaya Produksi (1) ........................ 79

Tabel 7.4. Hubungan Produksi dan Biaya Produksi (2)......................... 80

Tabel. 7.5. Skedul Produksi Jangka Panjang ..................................... 81

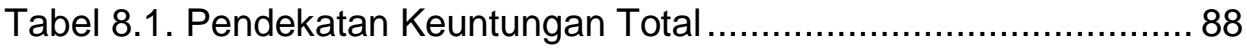

Tabel 8.2. Pendekatan Marginal ...................................................... 89

Tabel 9.1. Maksimisasi Keuntungan dalam Pasar Monopoli dengan Pendekatan Total dan Pendepatan Marginal ....................... 97 



\section{BAB I \\ PENDAHULUAN}

\section{TUJUAN INSTRUKSIONAL KHUSUS}

1. Mahasiswa dapat mendefinisikan konsep teori dan tujuan memahami teori

2. Mahasiswa dapat menjelaskan konsep kelangkaan ekonomi dan hubungannya dengan pembentukan model ekonomi

3. Mahasiswa dapat mendefinisikan teori ilmu ekonomi mikro

4. Mahasiswa dapat menjelaskan input dan output ekonomi dan arus barang dan jasa

\subsection{Definisi dan Tujuan Teori}

Pengertian dari teori adalah asumsi, konsep, dan definisi untuk menjelaskan suatu gejala/kondisi/kejadian secara sistematis dengan cara merumuskan hubungan antar konsep. Teori juga bisa diartikan sebagai suatu hipotesis yang telah diuji kebenarannya secara konsisten. Pengujian hipotesis tidak didasarkan pada realitas asumsinya melainkan pada kemampuannya untuk meramalkan dan menjelaskan suatu fenomena dengan tepat. Dengan demikian, tujuan teori adalah untuk menjelaskan dan meramalkan.

Salah satu asumsi dalam teori permintaan adalah setiap individu dapat mengukur utiliti atau kepuasan yang diterimanya sebagai akibat dari mengkonsumsi tiap unit barang tertentu. Asumsi ini tidak realistis karena manusia tidak dapat mengukur tingkat kepuasan yang dia terima. Namun asumsi ini tetap bisa diterima dalam teori permintaan karena kemampuannya dalam menjelaskan perilaku konsumen. Misalnya, konsumen seolah-olah dapat mengukur utility atau kepuasan yang diterima sehingga dia akan mengurangi jumlah barang yang dibeli apabila terjadi kenaikan harga. Sebaliknya, jika harga turun, konsumen akan membeli barang lebih banyak karena kepuasan yang diterima akan meningkat. 


\subsection{Kelangkaan Ekonomi}

Langka (scarce) adalah permasalahan yang dihadapi oleh setiap masyarakat. Hal ini berkaitan dengan konsep terbatas atau ekonomis. Kelangkaan terjadi karena adanya kesenjangan antara keinginan yang tidak terbatas dan ketersediaan barang yang sangat terbatas.

Kelangkaan terjadi karena terbatasnya ketersediaan sumberdaya ekonomi seperti modal, tanah, tenaga kerja dan sarana produksi lainnya. Sehingga kemampuan masyarakat untuk memproduksi barang dan jasa juga terbatas. Oleh karena itu mereka harus mempertimbangkan beberapa hal yaitu: apa yang akan diproduksi, siapa yang menjadi sasaran penjualan, bagaimana cara memproduksi, bagaimana mengalokasikan sumberdaya yang digunakan dari waktu ke waktu untuk mempertahankan kontinuitas produksi dan bagaimana mempertahankan usaha tersebut agar selalu menguntungkan.

\subsection{Model Ekonomi}

Kegiatan ekonomi modern semakin beragam macamnya. Ribuan bahkan jutaan perusahaan terlibat dalam memproduksi barang dan jasa. Satu perusahaan tersebut harus melakukan serangkaian kegiatan yang kompleks untuk menghasilkan produk mulai dari sektor hulu sampai dengan sektor hilirnya. Oleh karena itu, sangat tidak mungkin menjelaskan proses tersebut secara detail. Ahli ekonomi telah membuat penyederhanaan dari proses tersebut dengan mengidentifikasi hal-hal yang esensial saja untuk membuat sebuah model ekonomi yang sederhana. Tujuannya adalah untuk memahami isu-isu ekonomi yang akan mengambarkan bagaimana individu membuat keputusan, bagaimana perilaku perusahaan dan interaksi kedua grup tersebut di dalam mekanisme pasar.

Tidak semua model ekonomi mampu menjelaskan fenomena/gejala yang ada dengan baik. Adakalanya model tersebut tidak dapat menjelaskan dengan baik. Oleh karena itu model harus diverifikasi dengan memperhatikan validitas dari asumsi dasar yang digunakan dan kemampuan model dalam menjelaskan fenomena nyata.

\subsection{Definisi Ilmu Ekonomi}

Beberapa ahli ekonomi telah mendefinisikan ilmu ekonomi dari berbagai perspektif yang pada dasarnya mempunyai makna yang sama. 
Samuelson and Nordhaus (1995:4) menyatakan "Economics is the study of how societies use scarce resources to produce valuable commodities and distribute them among different people", atau ekonomi adalah ilmu yang mempelajari bagaimana masyarakat menggunakan sumberdaya yang terbatas untuk memproduksi barang dan mendistribusikannya kepada kelompok masyarakat yang lain.

Sebenarnya banyak lagi yang dapat kita jumpai definisi dari ilmu ekonomi yang dikemukakan oleh para ahli, namun secara umum dapat dikemukakan bahwa ilmu ekonomi didefinisikan sebagai ilmu tentang usaha manusia untuk memenuhi kebutuhannya (baik berupa barang dan jasa) yang jumlahnya tidak terbatas dengan menggunakan alat pemuas yang sifatnya terbatas. Jadi perlu diperhatikan bahwa ilmu ekonomi adalah ilmu yang memperhatikan perilaku manusia yang perhatian pokoknya adalah masalah pemilihan, baik pada saat sekarang ataupun pada masa yang akan datang dimana pilihan ini akan mempengaruhi produksi barang, distribusi, serta pengkonsumsian barang-barang tersebut. Setiap ekonom pada dasarnya mempunyai pendapat yang sama bahwa ekonomi meliputi scarcity (kelangkaan), kemakmuran dan kepuasan.

Perkembangan ilmu ekonomi sudah dimulai oleh aristoteles (350 SM) dan baru menjadi disiplin ilmu tersendiri sejak tahun 1776 dengan pelopor Adam Smith. Sedang ilmu ekonomi mikro yang kita kenal sekarang dirintis pengembangannya oleh Alfred Marshal dalam tahun 1870-an dengan bukunya: "Principle of Economics".

IImu ekonomi dikelompokkan menjadi menjadi 2 (dua) kelompok besar yaitu ilmu Ekonomi Mikro dan ilmu Ekonomi Makro. Ilmu ekonomi mikro membahas perilaku individual dari masing-masing pelaku ekonomi. Sedangkan analisis ekonomi makro membahas perilaku negara, masyarakat atau kelompok masyarakat, sehingga disebut teori pendapatan masyarakat. Variabel yang dibahas antara lain: a) pendapatan nasional, b) kesempatan kerja, c) pengangguran, d) inflasi, dan e) anggaran pemerintah.

\subsection{Definisi dan Fungsi Teori Ekonomi Mikro}

Samuelson and Nordhaus (1995:5) mendefinisikan ilmu ekonomi mikro sebagai berikut: Microeconomics is a branch of economic which is concerned with the behavior of individual entities such as markets, firms and households". Dari definisi di atas menjelaskan bahwa ilmu ekonomi mikro merupakan salah satu cabang ilmu ekonomi yang pembahasannya 
menitik beratkan pada perilaku ekonomi individu rumah tangga, perusahaan dan pasar. Ilmu ekonomi mikro memberikan suatu metode kepada seseorang atau rumah tangga untuk mengelola suatu sumber daya ekonomi secara efektif dan efisien. Ilmu ekonomi mikro menyediakan metode untuk menentukan barang yang dibeli dan berapa jumlahnya agar orang (konsumen) memperoleh kepuasan yang paling tinggi (maksimum).

\subsection{Kegiatan Ekonomi}

Perusahaan mengkombinasikan faktor produksi untuk menciptakan barang dan jasa yang di jual merupakan salah satu dari tiga macam kegiatan ekonomi. Menurut para ahli kegiatan ekonomi ada tiga macam (Boediono 1982) yaitu:

(a). kegiatan produksi,

(b). kegiatan konsumsi,

(c). kegiatan pertukaran.

Dalam masyarakat tradisional atau masyarakat subsisten, kegiatan produksi dan konsumsi dilakukan sendiri, namum dengan semakin berkembangnya peradaban maka kebutuhan manusia juga semakin beraneka ragam. Dengan kebutuhan yang makin meningkat inilah maka muncul adanya suatu pertukaran, karena seorang individu/rumah tangga tidak dapat memenuhi kebutuhannya sendiri.

Tujuan pengajaran teori ekonomi mikro yaitu menunjukkan caracara untuk menyederhanakan serta memecahkan permasalahan yang dihadapi secara sistimatis.

Kegunaan teori ekonomi yaitu untuk semua orang. Pengajaran dan pengkajian teori ekonomi dipengaruhi oleh kerangka pemikiran:

a. Tradisional, yang didasarkan pada gagasan:

- Adam Smith (1776) (klasik), yang memandang penting pada lembaga pemilikan perseorangan, kebebasan bertindak, dan kecintaan pada diri sendiri.

- Neoklasik, yang menggariskan bahwa kegiatan ekonomi setiap agen ekonomi dalam masyarakat (perusahaan, konsumen, tenaga kerja) mempunyai tujuan untuk mengoptimalkan pencapaian keuntungan. 
b. Radikal, yang bertolak dari buku Karl Marx, "Das kapital" (1848), yang kemudian dikenal sebagai radikal kiri.

Fungsi Teori Ekonomi adalah membantu untuk membuat keputusan yang terbaik (merupakan hasil optimal), hasil yang paling efektif dan efisien dalam konteks permasalahannya. Materi teori ekonomi mikro berkisar pada prinsip-prinsip yang dipakai sebagai dasar pengambilan keputusan sebuah perusahaan. Sedangkan alat analisis yang digunakan dalam ekonomi mikro adalah:
a. Verbal,
b. Tabel,
c. Diagram/Geometris/Grafis,
d. Matematis

\subsection{Sumber Daya Ekonomi}

Sumber daya ekonomi dapat diklasifikasikan menjadi 3 kelompok, yaitu sumber daya alam, sumber daya manusia, dan sumber daya modal. ( Endang Setyowati dkk, 2000:7).

a. Sumber daya alam.

Sumber daya alam merupakan faktor produksi yang langsung diperoleh dari alam, seperti tanah dan cadangan mineral yang terkandung di dalamnya.

b. Sumber daya Manusia.

Wujud dari SDM dalam proses produksi adalah waktu yang dihabiskan seseorang dalam melakukan kegiatan produksi. sementara itu sumber daya manusia yang tidak kalah pentingnya adalah kemampuan atau bakat kewirausahaan (entepreneurship) yang dimiliki oleh manusia.

c. Sumber daya Modal.

Wujud dari sumber daya modal adalah peralatan fisik yang digunakan dalam proses produksi, seperti: mesin, bangunan, truck, komputer dan lain sebagainya.

Contoh sederhana suatu proses produksi yang menggabungkan 3 macam sumberdaya adalah: seorang petani yang menggarap sebidang sawah untuk menanam padi dengan cara tradisional. Dalam proses produksi tersebut petani menggunakan sumber daya alam (tanah, kesuburan, cuaca, air dan udara), sumber daya manusia (Kemampuan petani), dan sumber daya modal (Cangkul). 


\subsection{Hasil Kegiatan Produksi}

Hasil kegiatan produksi yang dilakukan perusahaan adalah berupa barang dan jasa yang dibutuhkan oleh masyarakat. Untuk menghasilkan barang dan jasa tersebut, perusahaan memerlukan sumber daya yang pada pada umumnya sifatnya adalah terbatas (langka). Oleh karena itu agar tidak terjadi pemborosan, sebelum melakukan kegiatan produksi, maka perusahaan harus menjawab tiga pertanyaan pokok yaitu: What (Apa), How (bagaimana), dan for Whom (untuk siapa).

Pertanyaan What, berkenaan dengan barang dan jasa apa yang akan dihasilkan serta jumlahnya berapa. Pertanyaan How, berkenaan dengan bagaimana cara membuat atau memproduksi untuk menghasilkan barang atau jasa yang diinginkan. Sedangkan pertanyaan for whom, adalah berkenaan dengan untuk konsumen mana (siapa) barang dan jasa tersebut dan didistribusikan kemana barang dan jasa tersebut.

\subsection{Sistem Ekonomi}

Sistem ekonomi yang dianut dalam suatu negara akan berdampak pada mekanisme ekonomi tersebut dalam menjawab pertanyaan what, how dan for whom. Menurut Endang Setyowati dkk (2000:8) terdapat tiga macam sistem ekonomi, yaitu: sistem ekonomi pasar (market economy), sistem ekonomi komando (command economy) dan sistem ekonomi campuran (mixed economy).

Sistem ekonomi pasar menurut Samuelson and Nordhaus (1995:6) didefinisikan ; "A market economy is one in which individuals and private firms make the major decisions about production and consumption". Sistim ekonomi pasar ini biasanya digunakan oleh negara yang menganut sistem pemerintahan demokratik. Dalam sistem ekonomi pasar, perusahaan memproduksi barang atau jasa yang akan mendatangkan keuntungan paling tinggi (masalah what) dengan menggunakan ongkos produksi paling rendah (masalah how). Konsumsi ditentukan oleh keputusan individual tentang bagaimana membelanjakan penghasilannya (masalah for whom). Jadi dalam sistim ekonomi pasar ini segala keputusan ekonomi (produksi, konsumsi, dan pertukaran) ditentukan oleh perorangan atau individu perusahaan). 
Berbeda dengan sistem ekonomi komando, dalam sistem ekonomi komando ini segala keputusan mengenai kegiatan ekonomi (produksi, konsumsi, dan pertukaran) ditentukan oleh pemerintah. Samuelson and Nordhaus (1995:6) mendefinisikan sistem ekonomi komando adalah: "A command economy is one in which the government makes all dicision about production and distribution". Dalam sistim ekonomi komando pemerintah memungkinkan untuk mengatur aktivitas ekonomi. Hal ini disebabkan karena alat-alat produksi dikuasai oleh negara dan sebagian besar perusahaan dimiliki dan dikelola oleh negara.

Sedangkan sistem ekonomi yang ketiga adalah sistem ekonomi campuran. Pada kenyataannya sistem ekonomi yang banyak dianut adalah sistem ekonomi campuran, dimana masalah-masalah ekonomi dalam sistem ini sebagian diselesaikan melalui mekanisme pasar dan sebagian lagi melalui regulasi (peraturan) pemerintah.

\subsection{Aliran Barang, Uang dan Pasar}

Dalam bagian ini kita akan melihat bagaimana terjadinya aliran barang dan aliran uang dalam perekonomian yang sekaligus membentuk pasar. untuk lebih jelasnya dapat kita perhatikan gambar berikut:

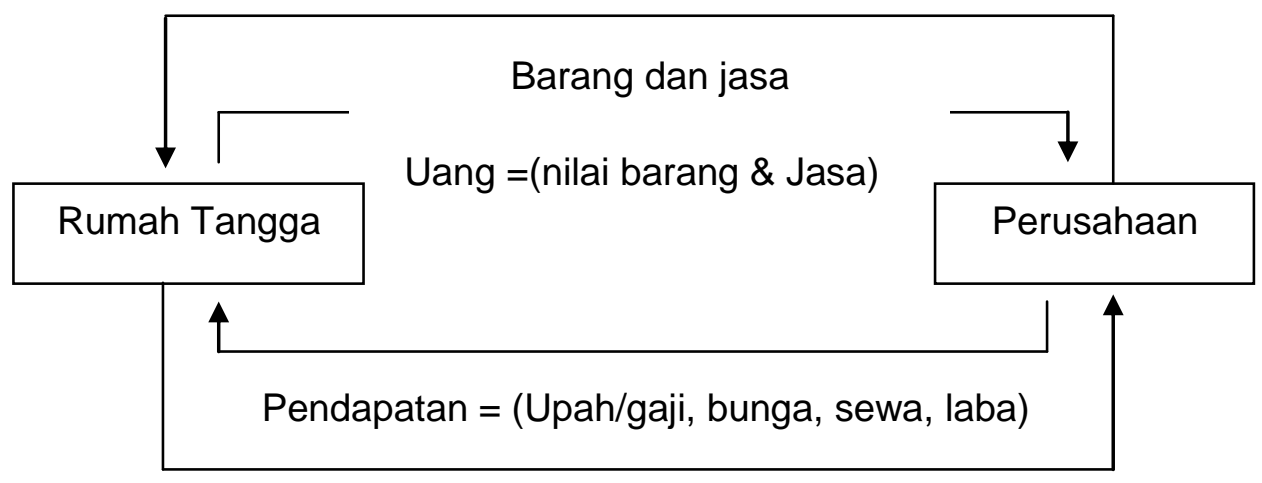

Faktor produksi =(tenaga kerja, modal, tanah, keahlian)

Sumber: Suparmoko, 1997: 15.

Gambar 1.1. Aliran Uang dan Barang

Kita misalkan hanya ada dua pelaksana (pelaku) ekonomi yaitu sektor rumah tangga dan sektor perusahaan. Sektor rumah tangga mengirim faktor produksi yang mereka memiliki seperti tenaga kerja, modal dan alat-alat kapital dan keahlian pada sektor perusahaan. 
Sebagai imbalannya sektor perusahaan memberikan imbalan berupa uang (upah / gaji) atas tenaga kerja, modal, alat-alat, dan tanah serta keahlian. Darimana perusahaan memperoleh uang ?. perusahaan mendapat uang dengan cara menjual produk dan jasa kepada sektor rumah tangga, dan sektor rumah tangga membayar harga barang dan jasa yang dibelinya dari sektor perusahaan. Oleh karena itu dalam gambar 1.1 dilingkaran dalam terdapat ada aliran uang dan dilingkaran luar terdapat aliran barang baik itu berupa faktor produksi maupun barang dan jasa.

Dari Gambar 1.1. tersebut tampak bahwa di lingkaran bagian atas terdapat pasar barang dan jasa dimana permintaan dan penawaran barang dan jasa bertemu disitu; sedangkan dilingkaran bagian bawah terdapat pasar faktor produksi yaitu pertemuan antara permintaan dan penawaran faktor produksi. Permintaan dan penawaran itu masingmasing akan menentukan harga keseimbangan dari barang dan faktor produksi yang diperdagangkan.

\subsection{Latihan Soal}

1. Sebut dan jelaskan definisi dari teori!

2. Apa yang dimaksud dengan model ekonomi dan apa tujuan dari dibuatnya model ekonomi?

3. Teori ekonomi dapat dikelompokkan menjadi dua yaitu ekonomi mikro dan ekonomi makro. Sebutkan perbedaan dan persamaan dari kedua cabang ilmu ekonomi tersebut!

4. Sebutkan alat analisis yang lazim dipergunakan dalam ekonomi mikro!

5. Gambarkan aliran barang, jasa dan uang dalam suatu perekonomian! Berikan penjelasan singkat!

\section{Istilah - istilah Penting:}

Opportunity Cost

IImu ekonomi, ilmu ekonomi mikro, ilmu ekonomi makro

Need and Want

Input dan output

Market Economy, Command Economy, dan Mixed Economy. 


\section{BAB 2 \\ TEORI PERMINTAAN}

\section{TUJUAN INSTRUKSIONAL KHUSUS}

1. Mahasiswa mampu menjelaskan pengertian permintaan

2. Mahasiswa dapat menerangkan dan mempraktekkan bagaimana terjadinya kurva permintaan

3. Mahasiswa dapat menjelaskan dan menunjukkan bagaimana terjadinya pergeseran dan pergerakan kurva permintaan.

\subsection{Fungsi Permintaan}

\subsubsection{Permintaan Individu terhadap Suatu Barang}

Seperti telah dikemukakan di muka, seorang atau individu dengan pendapatan yang terbatas jumlahnya akan membeli berbagai macam barang untuk memenuhi kebutuhan hidupnya. Teori ekonomi menggambarkan fenomena dari masyarakat.

Permintaan, dapat diartikan sebagai jumlah barang yang diminta individu pada berbagai tingkat harga. Permintaan efektif, yaitu permintaan yang didukung oleh kekuatan tenaga beli. Permintaan absolut atau potensial, yaitu permintaan yang hanya didasarkan pada kebutuhan saja.

Kurva permintaan, yaitu merupakan tempat kedudukan titik-titik yang menunjukkan hubungan antara berbagai tingkat harga dengan berbagai jumlah barang yang diminta.

Daya beli seseorang tergantung pada:

a. Pendapatan yang dapat dibelanjakan.

b. Harga barang yang dikehendaki.

Hukum permintaan menyatakan, bahwa bila harga suatu barang meningkat, maka kuantitas (jumlah) barang yang diminta akan berkurang atau menurun, dengan asumsi ceteris paribus berlaku. Sebaliknya, bila harga suatu barang menurun, maka jumlah barang yang diminta akan naik atau bertambah. 
Permintaan seseorang terhadap suatu barang dipengaruhi oleh banyak faktor, antara lain: harga barang itu sendiri, harga barang lain yang mempunyai hubungan (subsitusi atau komplementer) pendapatan konsumen, selera, jumlah anggota keluarga, ramalan dan lain sebagainya.

Hubungan antara jumlah suatu barang yang diminta (sebagai variabel dependen) dengan berbagai faktor yang mempengaruhinya (sebagai variabel independen), secara matematis dapat dinyatakan sebagai berikut:

\section{$Q_{d}=f\left(P_{x}, P_{y}, P_{z}, S, Y, \ldots \ldots\right)$}

Dimana:

$Q_{d} \quad=$ Jumlah permintaan barang $X$

$\mathrm{P}_{\mathrm{x}} \quad=$ Harga barang $\mathrm{x}$

$P_{y} \quad=$ Harga barang $y$

$\mathrm{P}_{\mathrm{z}} \quad$ = Harga barang $\mathrm{z}$

$\mathrm{S} \quad=$ Selera

$\mathrm{Y} \quad=$ Pendapatan

Semakin tinggi harga suatu barang dengan menganggap faktorfaktor lain selain harga itu sendiri tidak berubah (ceteris paribus), maka jumlah barang yang diminta oleh konsumen semakin sedikit, dan sebaliknya semakin rendah harga suatu barang, maka jumlah yang diminta adalah semakin banyak. Dengan demikian secara sederhana, jumlah suatu barang yang diminta yang dipengaruhi oleh harga barang itu sendiri, ceteris paribus dapat dituliskan dalam fungsi matematis sebagai berikut:

$Q d x=f(P x)$ Ceteris paribus.

Qdx merupakan variabel dependen (tidak bebas) karena besarnya akan ditentukan oleh variabel lain $(P x)$. Sedangkan $P x$ merupakan variabel independen (bebas) karena variabel ini tidak ditentukan oleh variabel lain. 
Tabel 2.1. Skedul Permintaan terhadap Suatu Barang X

\begin{tabular}{|c|c|c|}
\hline Kondisi & Harga (Rp. per unit) atau Px & $\begin{array}{c}\text { Jumlah yang diminta } \\
\text { (unit pertahun) atau Qx }\end{array}$ \\
\hline A & 10 & 20 \\
B & 8 & 40 \\
C & 6 & 60 \\
D & 4 & 80 \\
E & 2 & 100 \\
\hline
\end{tabular}

Dari data dalam Tabel 2.1. apabila di gambarkan dalam sebuah grafik atau kurva, maka akan nampak gambarnya sebagai berikut:

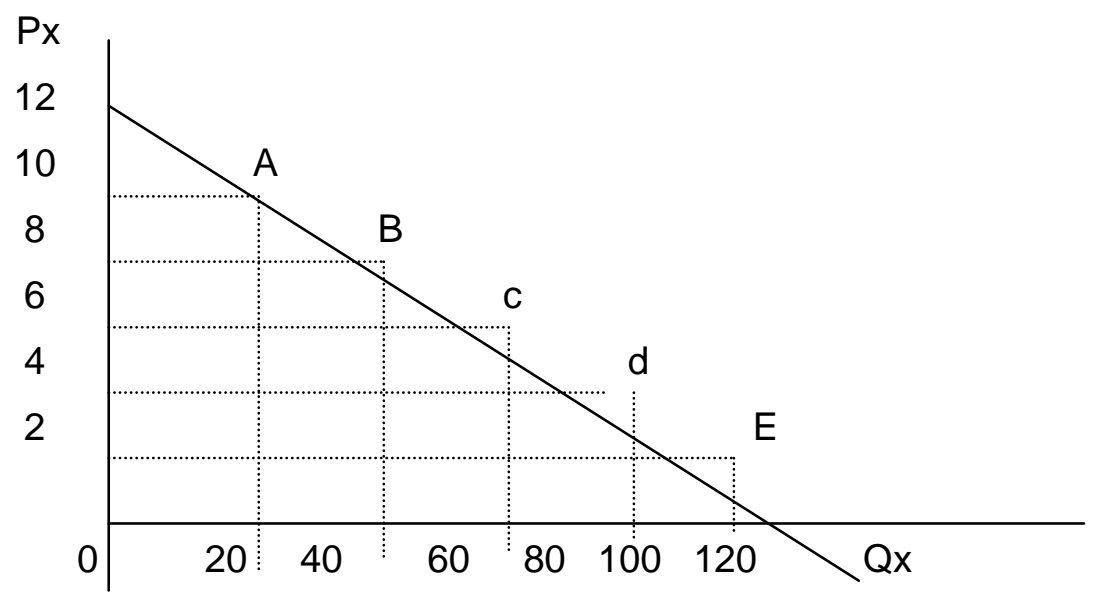

Gambar 2.1. Kurva Permintaan Suatu Barang

Dari kurva tersebut dapat disimpulkan bahwa jumlah barang yang diminta dan harga per unit barang berhubungan terbalik (negatif). Jumlah barang yang diminta $(\mathrm{Qx})$ akan naik apabila harga per unit untuk barang $X(P x)$ turun dan sebaliknya. Kondisi semacam ini disebut dengan "hukum permintaan".

Hukum permintaan: Apabila harga suatu barang naik, dan faktor-faktor lain dianggap tidak berubah (ceteris paribus), maka pembeli cenderung akan membeli jumlah barang tersebut dalam jumlah sedikit. Sebaliknya, apabila harga suatu barang menurun, pembeli cenderung membeli jumlah barang tersebut lebih banyak. 


\subsubsection{Perubahan Jumlah Barang yang Diminta}

Mengapa jumlah yang diminta cenderung menurun pada saat harganya naik? Untuk menjawab pertanyaan tersebut maka terdapat dua alasan yang dapat digunakan (Endang Setyowati dkk, 2000:23):

1. Adanya efek Subtitusi.

Apabila harga suatu barang naik, maka konsumen akan menggantikannya dengan barang yang harganya lebih rendah, akan tetapi barang tersebut harus bersifat subtitusi (pengganti). Contoh: apabila harga daging sapi naik, sementara konsumen membutuhkan daging sedangkan anggaran yang dimiliki adalah terbatas maka dia akan menggantikan daging sapi tersebut dengan daging kerbau, kambing atau bahkan daging ayam.

\section{Adanya efek Pendapatan.}

Apabila suatu harga barang naik dengan pendapatan yang terbatas, maka konsumen akan menjadi lebih miskin dari sebelumnya atau pendapatan riil konsumen menurun. Dengan pendapatan riil yang semakin menurun maka konsumen akan cenderung membatasi pembelian terhadap suatu barang. Dengan demikian efek pendapatan akan akan memperkuat efek subtitusi untuk menegaskan bahwa kurve permintaan akan mempunyai kemiringan yang negatif, jumlah yang diminta cenderung akan turun pada saat harganya naik dan sebaliknya jumlah yang diminta akan naik pada saat harganya turun.

Contoh kasus riil yaitu terjadi pada saat negara Indonesia sedang mengalami krisis ekonomi yang maha hebat akhir-akhir ini, harga secara umum mengalami kenaikan dua sampai tiga kali lipat, dengan pendapatan yang tetap, maka rakyat Indonesia menjadi semakin miskin atau pendapatan riil masyarakat adalah semakin menurun. Untuk lebih memahami teori ini maka contoh sederhana adalah sebagai berikut: Apabila daging sapi harganya Rp. 15. 000,- / Kg, saya akan membeli sebanyak $2000 \mathrm{Kg}$ untuk setiap tahunnya, tetapi setelah harga daging sapi naik menjadi Rp. 30. 000,- / Kg, maka saya akan membeli sebanyak $1000 \mathrm{Kg}$ per tahunnya. 


\subsubsection{Perubahan Permintaan}

Selain harga barang itu sendiri, terdapat faktor lain yang dapat mempengaruhi jumlah (kuantitas) barang yang diminta. Kenaikan pendapatan nominal merupakan faktor yang cenderung membuat kita berbelanja lebih banyak. Untuk kasus barang mewah lebih responsif dibandingkan dengan barang normal.

Apabila salah satu syarat dari ceteris paribus berubah, maka kurva permintaan akan bergeser. Hal ini disebut sebagai suatu perubahan permintaan. Perubahan permintaan berbeda dengan perubahan jumlah barang yang diminta. Perubahan jumlah barang yang diminta hanya akan bergerak disepanjang kurva permintaan yang disebabkan perubahan harga barang tersebut. Untuk lebih jelasnya marilah kita perhatikan Gambar 2.2, dimana gambar tersebut menunjukkan perbedaan perubahan permintaan dan perubahan barang yang diminta. Panel (a) menunjukkan bahwa perubahan jumlah barang yang diminta akibat adanya perubahan harga. Pada tingkat harga $P_{1}$ maka jumlah yang diminta hanya $Q_{1}$, selanjutnya pada saat harga turun ke $P_{0}$ maka jumlah barang yang diminta semakin tinggi menjadi $Q_{0}$. Inilah yang dimaksud dengan pergeseran sepanjang kurva.
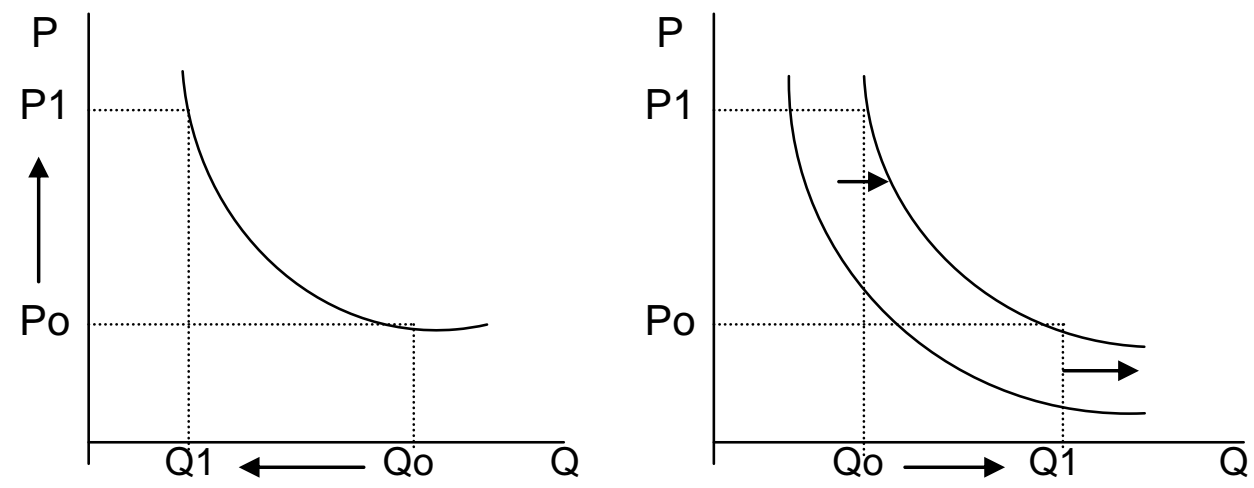

(a). Perubahan jumlah yg diminta (b). Perubahan permintaan.

Gambar 2.2.Perbedaan Jumlah Permintaan dan Jumlah yang Diminta

Perubahan permintaan yang ditunjukkan pada gambar (b) di atas terjadi karena dengan sejumlah barang yang sama konsumen bersedia membayar dengan harga lebih tinggi, yaitu dari Po ke P1 atau dengan 
harga yang sama konsuemen bersedia membeli lebih banyak, yaitu dari Qo ke Q1.

Perubahan cita rasa seseorang atas suatu komoditi akan menyebabkan pergeseran kurva permintaan orang itu terhadap komoditi tersebut. Apabila seseorang mempunyai keinginan yang semakin besar untuk mengkonsumsi es krim, maka kurva permintaannya akan bergeser ke kanan atau ke atas.

\subsubsection{Permintaan Pasar}

Bahasan permintaan telah sampai pada kurva permintaan. Sehingga pada akhirnmya akan muncul pertanyaan: dari semua permintaan-permintaan yang telah dibahas di atas, permintaan siapakah itu?. Jumlah suatu barang yang seorang atau individu bersedia membayar akan ditentukan oleh banyak faktor seperti telah dikemukakan di muka, yaitu harga barang itu sendiri, harga barang lain yang mempunyai hubungan (subtitusi, komplementer); pendapatan seseorang; selera; ramalan keadaan dimasa yang akan datang dan lain sebaginya.

Di dalam suatu pasar tentunya banyak permintaan yang terjadi oleh konsumen kepada produsen, masing-masing konsumen mempunyai permintaan yang jumlahnya tidak sama. Adakalanya seorang indiviu konsumen mempunyai permintaan yang lebih banyak dibandingkan dengan individu yang lain atau bahkan sebaliknya. Dari jumlah permintan individu-individu tersebut apabila di jumlahkan akan menjadi suatu permintaan pasar. Jadi, dapat disimpulkan bahwa yang dinamakan permintaan pasar adalah penjumlahan dari permintaan individu-individu yang ada di dalam suatu pasar. Untuk lebih memudahkan pemahaman maka dapat dilihat contoh tabel berikut:

Tabel 2.2. Permintaan Individu dan Permintaan Pasar

\begin{tabular}{|r|r|r|r|r|}
\hline Harga (P) & \multicolumn{1}{|c|}{$\begin{array}{c}\text { Permintaan } \\
\text { Amir (Q1) }\end{array}$} & $\begin{array}{r}\text { Permintaan } \\
\text { Ahmad (Q2) }\end{array}$ & $\begin{array}{r}\text { Permintaan } \\
\text { Rahma (Q3) }\end{array}$ & $\begin{array}{c}\text { Permintaan } \\
\text { pasar (Q) }\end{array}$ \\
\hline Rp. 15.000 & $2.000 \mathrm{Kg}$ & $3.000 \mathrm{Kg}$ & $1.500 \mathrm{Kg}$ & $6.500 \mathrm{Kg}$ \\
Rp. 30.000 & $1.000 \mathrm{Kg}$ & $1.500 \mathrm{Kg}$ & $750 \mathrm{Kg}$ & $3.250 \mathrm{Kg}$ \\
\hline
\end{tabular}


Dari Tabel 2.2. dapat diketahui bahwa permintaan akan daging sapi antara individu Amir, ahmad, dan Rahma pada akhirnya akan menjadi sebuh permintaan pasar. Baik ketika harga itu mula-mula dianggap murah sampai ketika harga tersebut menjadi naik.

\subsubsection{Barang Inferior, Normal dan Superior}

Perubahan pendapatan seseorang akan menggeser permintaan terhadap suatu barang. Jika barang yang dikonsumsi adalah "Barang Normal", terdapat hubungan positif antara perubahan pendapatan dan perubahan permintaan. Jika pendapatan meningkat maka permintaan juga akan meningkat (kurva permintaan akan bergeser ke kanan) dan sebaliknya jika pendapatan menurun maka permintaan juga akan menurun (kurva permintaan akan bergeser ke kiri). Gambar 2.3. (a), menunjukkan bahwa kurva permintaan awal adalah $D_{0}$. Jika pendapatan meningkat maka kurva permintaan bergeser ke kanan menjadi $D_{1}$ dan sebaliknya kurva permintaan akan menjadi $D_{2}$ jika pendapatan seseorang menurun.

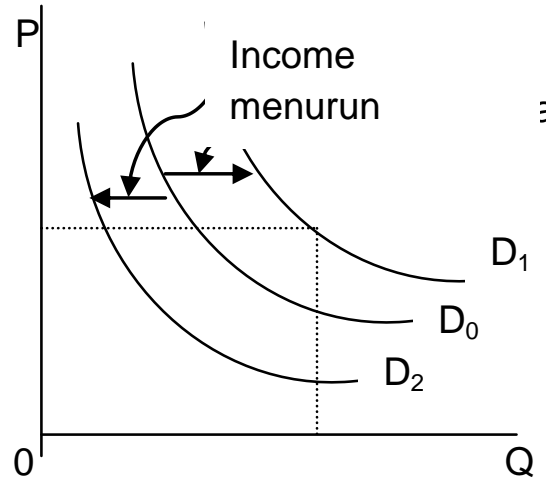

(a). Barang Normal

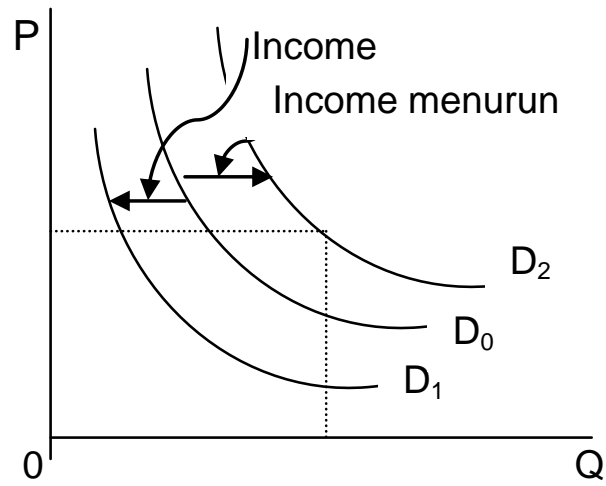

(b). Barang Inferior

Gambar 2.3. Pergeseran Permintaan pada Barang Normal dan Inferior

Sedangkan barang inferior mempunyai karakteristik "hubungan negatif" antara perubahan pendapatan dan perubahan permintaan. Gambar 2.3. (b) menunjukkan fenomena tersebut. Apabila pendapatan seseorang meningkatkan, maka kurva permintaan bergeser ke kiri dari $D_{0}$ ke $D_{1}$. Artinya peningkatan pendapatan menyebabkan penurunan 
konsumsi terhadap barang inferior. Sedangkan apabila pendapatan menurun, maka kurva permintaan akan bergeser ke kanan (bergeser dari $D_{0}$ ke $D_{2}$ ). Contoh dari barang inferior adalah gaplek. Kelompok orang kaya akan semakin menurunkan konsumsi gaplek dan cenderung menambah jumlah konsumsi beras atau bahan makanan pokok lainnya.

Barang superior adalah barang normal yang mempunyai karakteristik khusus. Jenis barang ini juga mempunyai hubungan positif antara perubahan pendapatan dan perubahan konsumsi seperti barang normal. Namun persentase perubahan permintaan jauh lebih besar bila dibandingkan dengan persentase perubahan pendapatan. Apabila dibandingkan pola perubahan permintaan beras (barang normal) dan berlian (barang superior), maka Nampak bahwa jika pendapatan berubah maka perubahan permintaan beras tidak begitu besar karena konsumen sangat membutuhkan barang ini sebagai bahan makanan pokok. Artinya perubahan permintaan tidak terlalu responsive apabila ada perubahan permintaan. Sebaliknya, pada berlian (barang superior), perubahan pendapatan sedikit saja akan sangat berdampak terhadap perubahan permintaan terhadap berlian.

\subsubsection{Barang Komplementer dan Substitusi}

Permintaan suatu barang $\left(Q_{x}\right)$ dipengaruhi oleh beberapa faktor diantaranya adalah pendapatan konsumen dan harga barang lainnya yang relevan $\left(P_{y}\right)$. Kedua barang dapat mempunyai hubungan yang bersifat substitusi atau saling menggantikan dan yang kedua bersifat komplementer atau saling melengkapi. Gambar 2.4. menunjukkan hubungan tersebut.

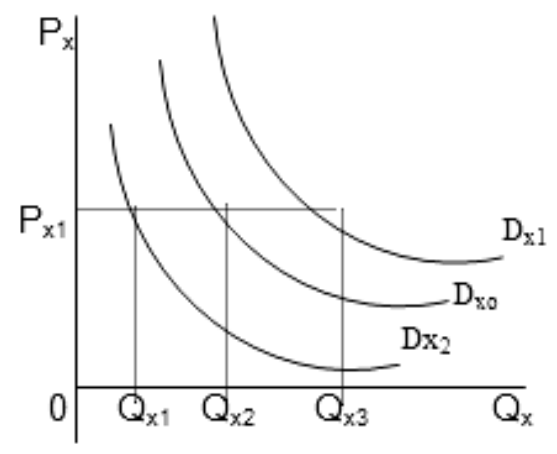

(a). Panel A

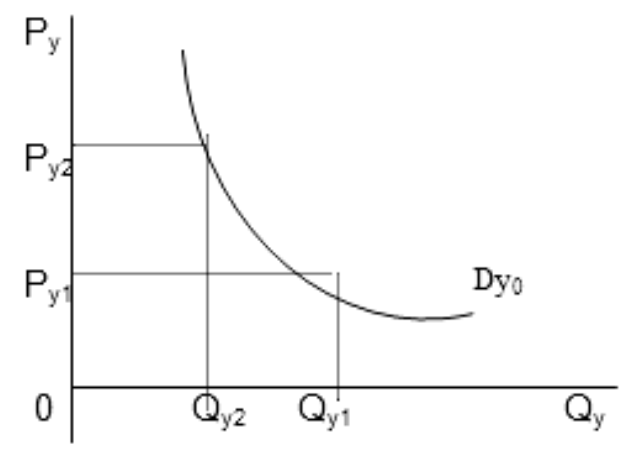

(b). Panel B

Gambar 2.4. Perilaku Dua Barang yang Bersifat Substitusi 
Perilaku dua barang yang saling subsitusi adalah saling menggantikan. Apabila terjadi perubahan harga terhadap suatu barang maka konsumen akan mencari alternatif barang. Misalnya seseorang beralih dari minum kopi ke minum teh karena adanya perubahan harga kopi. Gambar 2.4. (b) menunjukkan bahwa harga barang $Y$ naik dari $P_{y 1}$ ke $P_{y 2}$, akibatnya jumlah permintaan barang $Y$ turun dari $Q_{y 1}$ ke $Q_{y 2 .}$ Selanjutnya konsumen beralih ke barang substitusinya yang dalam contoh ini adalah barang $X$. Dampaknya permintaan barang $X$ meningkat dan menggeser kurva dari $D_{x 0}$ ke $D_{x 1}$ dan jumlah barang yang diminta naik dari $Q_{x 2}$ ke $Q_{x 3}$.

Gambar 2.5. dibawah ini menunjukkan hubungan antara dua barang yang saling komplementer. Contoh paling konkret adalah hubungan antara konsumsi gula dan kopi. Apabila harga kopi naik maka permintaan akan kopi akan menurun. Penurunan permintaan kopi akan direspon dengan penurunan konsumsi gula sebagai barang pelengkapnya.

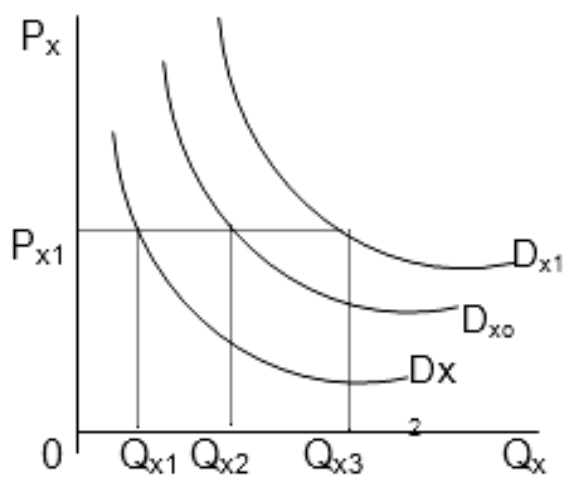

(a). Panel A

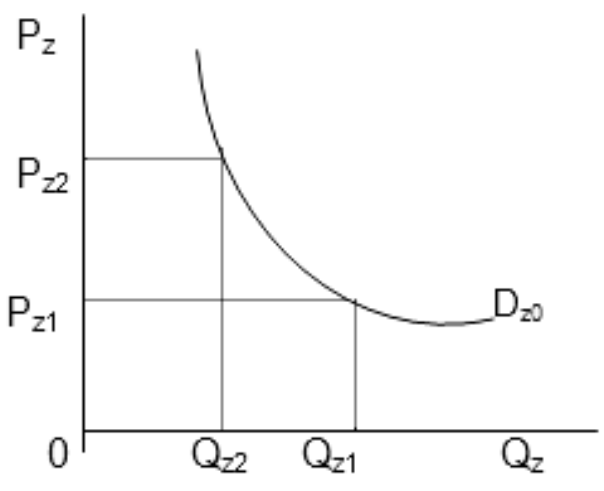

(b). Panel B

Gambar 2.5. Perilaku Dua Barang yang Bersifat Komplementer

Apabila harga barang $Z$ naik dari $P_{z 1}$ ke $P_{z 2}$, maka konsumsi atau permintaan barang $Z$ akan menurun $\left(Q_{z 1}\right.$ ke $\left.Q_{z 2}\right)$. Dalam hubungan barang yang komplementer, penurunan permintaan barang $Z$ akan direspon dengan pergeseran kurva permintaan barang $X$ dari $D_{x 0}$ ke $D_{x 2 .}$ Artinya, terjadi penurunan konsumsi barang $X$ dari $Q_{x 1}$ ke $Q_{x 2}$. 


\subsection{Teori Perilaku Konsumen}

\subsubsection{Teori Utilitas Kardinal}

Utuliti atau kepuasan adalah kapasitas suatu barang atau jasa untuk memuaskan kebutuhan manusia. Ini adalah salah satu pendekatan yang menjelaskan fenomena sebuah nilai yang merupakan fondasi dari aliran neo-klasik. Namun, pada dasarnya penilaian suatu utiliti adalah bersifat subyektif dan tidak dapat diukur secara langsung.

Seseorang mengkonsumsi suatu barang tertentu karena kepuasan atau utiliti yang diterimanya. Logikanya, sampai dengan titik tertentu seseorang akan mendapatkan utiliti yang lebih besar jika mengkonsumsi barang lebih banyak. Namun, peningkatan level kepuasan yang diterima akan semakin mengecil. Contohnya, pada saat meminum segelas es, kita merasakan kepuasan yang luar biasa. Pada saat mengkonsumsi gelas yang kedua, kepuasan yang dirasakan semakin besar. Namun, peningkatan level kepuasan akan semakin menurun pada saat kita mengkonsumsi es pada gelas ketiga dan seterusnya. Bahkan pada gelas tertentu bukan kepuasan yang diterima tapi justru kita sakit perut karena terlalu banyak mengkonsumsi es.

Definisi dari total utiliti (TU) adalah jumlah kepuasan yang diterima karena mengkonsumsi satu unit barang. Secara matematis dapat dinyatakan sebagai berikut:

Total Utiliti $=T U=f(Q$, selera,$\ldots)$

Dimana:

$\mathrm{Q}=$ Jumlah barang yang dikonsumsi

Dari formulasi diatas, dapat dijelaskan bahwa total utiliti atau kepuasan yang diterima tergantung pada jumlah barang yang dikonsumsi, selera dan faktor-faktor lainnya.

Sedangkan marginal utiliti (MU) adalah perubahan total utiliti yang diterima sebagai akibat dari perubahan satu unit barang yang dikonsumsi. Formulasi matematisnya adalah:

$$
\text { Marginal Utility }=M U=\frac{\Delta T U}{\Delta Q}
$$

Sebagaimana disebutkan diatas, semakin banyak barang yang dikonsumsi semakin besar TU yang diperoleh dengan tingkat pertambahan yang semakin menurun. Pada level tertentu, TU yang diterima akan mencapai titik maksimum dan setelah itu akan menurun. 


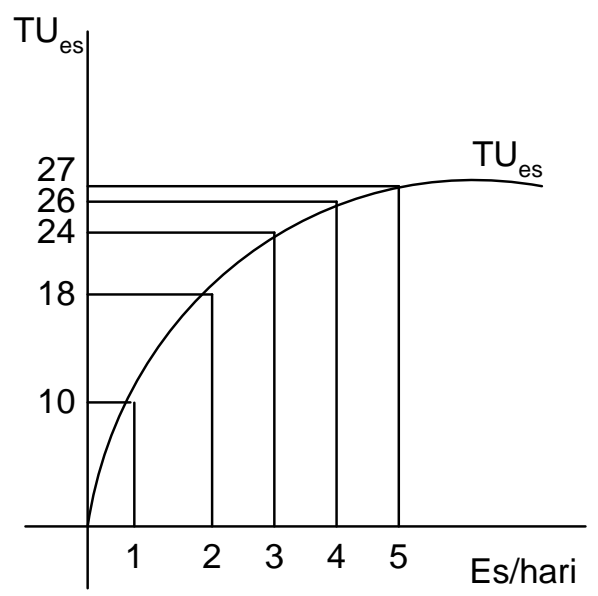

Gambar 2.6. Kurva Total Utiliti

Pada Gambar 2.6. diketahui bahwa total utility yang diperoleh dari mengkonsumsi es terus meningkat sampai dengan 27 yang diraih pada gelas es yang kelima. Sehingga kita ketahui bahwa total utility adalah fungsi dari jumlah barang yang dikonsumsi dan preferensi. Pada saat seseorang mengkonsumsi 1 gelas tingkat kepuasannya adalah 10.Konsumsi 2 gelas es akan menghasilkan kepuasan 18 dan seterusnya. Apabila seseorang tersebut mengkonsumsi lebih dari 5 gelas es per hari maka tingkat kepuasan yang diperoleh justru menurun.

Total utility yang diilustrasikan pada Gambar 2.6. dapat ditampilkan dalam bentuk Tabel 2.3. dibawah ini.

Tabel 2.3. Total dan Marginal Utility

\begin{tabular}{|c|c|c|}
\hline KUANTITAS & TOTAL UTILITY & MARGINAL UTILITY \\
\hline 0 & 0 & --- \\
\hline 1 & 10 & 10 \\
\hline 2 & 18 & 8 \\
\hline 3 & 24 & 6 \\
\hline 4 & 26 & 2 \\
\hline 5 & 27 & 1 \\
\hline 6 & 26 & -1 \\
\hline
\end{tabular}

Tabel 2.3. juga menunjukkan besarnya nilai marginal utility. Nilai ini dapat dihitung dari perubahan total utility sebagai akibat dari 
perubahan 1 unit barang yang diminta. Sebagai contoh, Marginal Utility gelas pertama $\left(\mathrm{MU}_{1}\right)$ adalah sebagai berikut:

$$
\begin{aligned}
& M U_{1}=\frac{\Delta T U}{\Delta Q} \\
& M U_{1}=\frac{(10-0)}{(1-0)} \\
& M U_{1}=10
\end{aligned}
$$

Jadi nilai marginal utility dari gelas es yang pertama adalah 10.Dengan langkah yang sama dapat dicari nilai marginal utility dari penambahan masing-masing gelas. Sedangkan pada gelas yang keenam, $\mathrm{MU}_{6}$ adalah sebagai berikut:

$$
\begin{aligned}
& M U_{6}=\frac{\Delta T U}{\Delta Q} \\
& M U_{6}=\frac{(26-27)}{(6-5)} \\
& M U_{6}=-1
\end{aligned}
$$

Dari perhitungan diatas nampak bahwa, marginal utility atau tambahan kepuasan negatif pada tingkat konsumsi es sebanyak enam gelas. Hal ini berarti total utility yang diperoleh pada gelas keenam (26) lebih kecil dari total utility yang diperoleh pada gelas yang kelima (27).

Gambar 2.7. menjelaskan bahwa Marginal Utility merupakan slope/kemiringan dari Total Utility diantara dua titik. Marginal utility dari gelas es yang ketiga adalah slope dari Total Utility antara titik A dan B. Jadi slope dari garis $A B$ adalah pembagian dari perubahan TU terhadap perubahan jumlah es yang dikonsumsi. Sebagai contoh $\triangle Q$ adalah 1 (dari gelas kedua ke gelas ketiga) dan $\Delta T U$ adalah 6 (24-18). Sehingga $\mathrm{MU}$ adalah $M U=\frac{6}{1}=6$. 


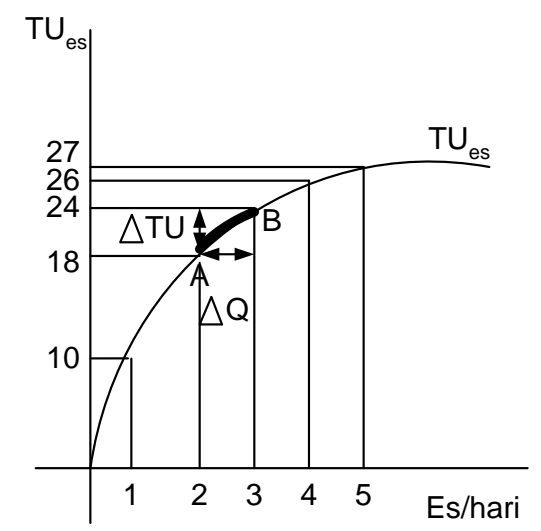

Gambar 2.7. Derivasi Nilai Marginal Utiliti dari Total Utiliti

Hubungan antara total utility (TU), marginal utility (MU) dan average utility (AU) ditunjukkan pada Gambar 2.8. Pada gambar tersebut, TU mempunyai beberapa karakteristik sehingga berbagai bentuk dari TU dapat dijelaskan.

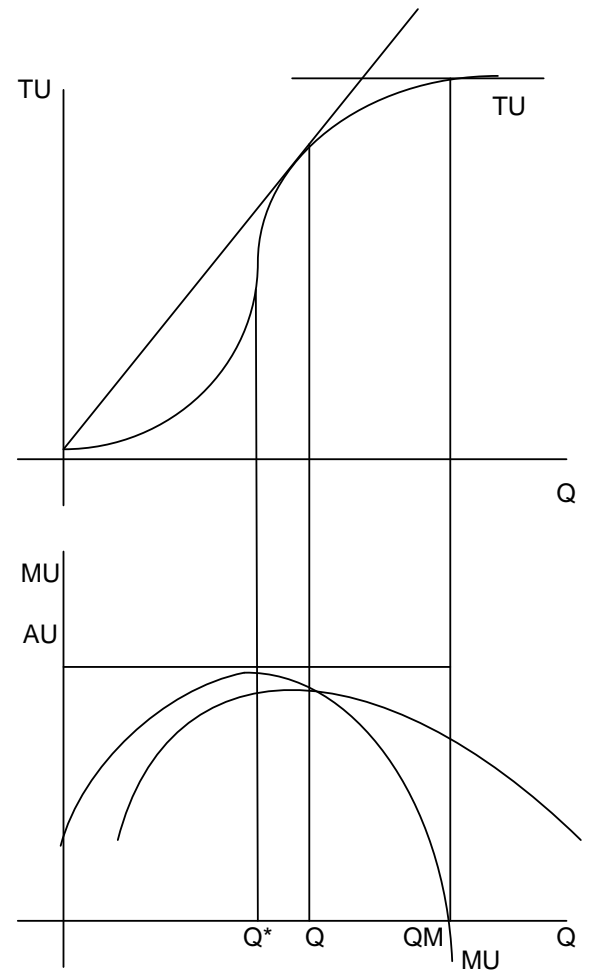

Gambar 2.8. Hubungan antara Marginal Utility, Average Utility dan Total Utility 
Pada contoh diatas, di fase awal TU meningkat dengan tingkat pertambahan yang semakin menaik. Setiap penambahan satu unit barang yang dikonsumsi akan menambah TU dengan tingkat pertambahan yang semakin besar. Pada range ini, nilai MU terus mengalami peningkatan. Pada tingkat konsumsi $Q^{*}$ telah tercapai titik balik (inflection point) pada TU. Pada titik ini nilai MU sama dengan AU $(\mathrm{MU}=\mathrm{AU})$ dan $\mathrm{MU}$ juga mencapai titik maksimum. Selanjutnya TU tetap naik tapi dengan tingkat kenaikan yang semakin menurun. Hal ini konsisten dengan kondisi penurunan MU. TU akan mencapai titik maksimal pada saat $M U=0$. Setelah tingkat konsumsi tersebut nilai TU akan menurun dan MU negatif.

Kurva average utility akan meningkat sejak titik asal sampai pada titik dimana marginal utility berpotongan dengan average utility. Peningkatan nilai average utility selalu lebih rendah dari peningkatan nilai marginal utility. Setelah itu average utility akan terus menurun tapi penurunan average utility selalu lebih rendah dari penurunan nilai marginal utility.

\subsubsection{Teori Kurva Indiferen}

\subsubsection{Definisi dan Asumsi Kurva Indiferen}

Kurva indiferen atau kuva kepuasan sama adalah kombinasi titik yang menunjukkan hubungan antara tingkat konsumsi komoditi $X$ dan komoditi $Y$ yang menghasilkan tingkat kepuasan yang sama. Seseorang bisa memilih komposisi jumlah komoditi $X$ dan $Y$ yang akan dikonsumsi asalkan tingkat kepuasan yang diperoleh sama. Kurva indiferen yang lebih tinggi merepresentasikan bahwa tingkat kepuasan yang diperoleh adalah lebih tinggi. Sebaliknya tingkat kepuasan yang lebih rendah dicerminkan dari letak kurva indiferen yang lebih rendah.

Gambar 2.9.menjelaskan kurva indiferen yang menggambarkan kombinasi barang $X$ dan $Y$. Semakin jauh dari titik asal semakin disukai konsumen karena barang yang dikonsumsi lebih banyak dibandingkan dengan yang lebih dekat terhadap titik asal. Pada Gambar 3. 4. , menunjukkan bahwa kombinasi P, Q dan R menghasilkan tingkat kepuasan yang sama yaitu I. 


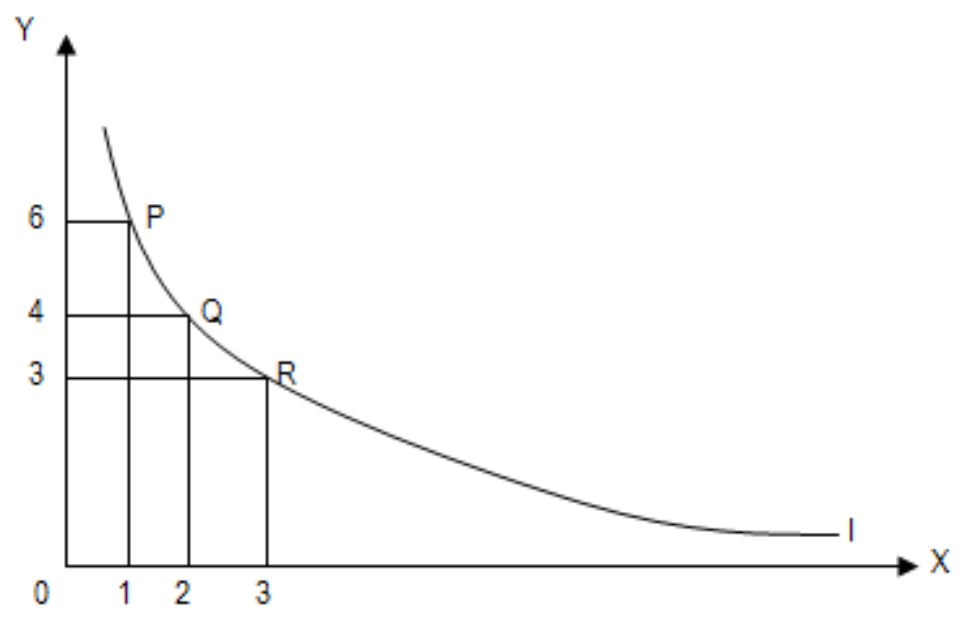

Gambar 2.9.Kurva Indiferen

Hal ini memberikan ilustrasi tentang tentang preferensi konsumen yang lebih menyukai suatu kombinasi dibandingkan kombinasi yang lain. Seperti ditunjukkan pada gambar 2.9.teori di atas tidak mejelaskan kombinasi manakah yang lebih disukai oleh konsumen, tetapi kombinasi $\mathrm{P}, \mathrm{Q}$ atau $\mathrm{R}$ menghasilkan preferensi atau kepuasan yang sama.

Adapun asumsi dari teori kurva indiferen adalah sebagai berikut:

\section{Rasionalitas}

Konsumen diasumsi selalu bertindak dengan pemikiran yang rasional. Dia bertujuan untuk memaksimalkan tingkat kepuasan yang diperoleh sesuai dengan tingkat pendapatan dan harga pasar dari produk tersebut. Diasumsikan pula bahwa konsumen mempunyai informasi yang relevan.

2. Utility atau tingkat kepuasan adalah ordinal

Konsumen dianggap dapat merangking tingkat kepuasan yang mereka terima atau mereka dapat mengurutkan tingkat kepuasan dari beberapa jenis barang yang dikonsumsi. Jadi yang terpenting disini adalah konsumen dapat mengurutkan tingkat kepuasan yang diterima. Namun, mereka tidak perlu mengetahui jumlah riil tingkat kepuasan yang diterima.

Misalnya diasumsikan ada dua barang atau saja yang dibutuhkan oleh konsumen yaitu $X_{1}$ dan $X_{2}$.Untuk setiap kombinasi $X_{1}$ dan $X_{2}$, konsumen dapat memutuskan mana yang lebih disukai. Apakah $\mathrm{X}_{1}$ lebih disukai dari $X_{2}$ atau $X_{2}$ lebih disukai dari $X_{1}$. Hal ini dapat dituliskan sebagai $X_{1}>X_{2}, X_{2}>X_{1}$. Kaidah kelengkapan kombinasi 
barang yang dibutuhkan memungkinkan seorang konsumen dapat mengurutkan produk-produk $\left(\mathrm{X}_{1}\right.$ dan $\left.\mathrm{X}_{2}\right)$ dari yang paling tidak disukai sampai paling disukai. Walaupun terkadang konsumen tidak bisa menentukan kombinasi produk $X_{1}$ dan $X_{2}$ yang paling disukai karena permasalahan asimetris informasi atau konsumen tidak mendapatkan akses informasi yang benar dan akurat. .

3. Tingkat substitusi marginal yang semakin menurun

Kepuasan konsumen dirangking menurut kurva indiferen dengan asumsi bahwa tingkat kepuasan tersebut cembung terhadap titik nol. Slope kurva indiferen disebutkan juga dengan tingkat substitusi marginal. Kurva indiferen mempunyai tingkat substitusi marginal yang semakin menurun.

Kemiringan kurva indiferen masing-masing individu tentunya akan berbeda. Konsep yang dapat menjelaskan preferensi/selera seorang konsumen adalah tingkat subsitusi marjinal (TSM) yang merupakan nilai absolut dari kemiringan kurva indiferen. TSM menjelaskan berapa jumlah konsumsi barang dan jasa yang bersedia dikurangi untuk subtitusi dengan barang dan jasa lainnya, tanpa merubah tingkat kepuasan yang diterima oleh konsumen sebelum dan sesudah terjadinya substitusi konsumsi barang dan jasa tersebut.

Implementasi dari TSM dijelaskan oleh Gambar 2.9 di atas. Konsumen dikatakan bersifat indiferen dalam mengkonsumsi kombinasi $P$ dan $Q$ apabila mereka beralih dari kombinasi $P$ ke $Q$, maka dia harus mengurangi konsumsi $Y$ sebanyak 2 unit untuk menambah konsumsi $X$ sebanyak 1 unit. Dengan demikian TSM antara $Y$ dan $X$ adalah 2 jika konsumen berubah dari kombinasi $P$ ke $Q$. Apabila konsumen beralih dari $Q$ ke $R$, konsumen mendapat tambahan barang $X$ sebanyak 1 unit. Tetapi jumlah $Y$ yang bersedia dikorbankan oleh konsumen hanya sebesar 1 unit juga. Hal ini terjadi karena jumlah barang $Y$ yang dimiliki konsumen semakin sedikit, akibatnya dia hanya bersedia menukar sedikit $Y$ untuk mendapatkan 1 tambahan $X$. Hal ini disebut sebagai TSM yang menurun. Jadi TSM yang menurun adalah jumlah produk $Y$ yang bersedia dikorbankan oleh seorang konsumen akan semakin kecil untuk mendapatkan tambahan produk $X$ sebanyak 1 unit.

Adapun slope kurva indiferen dapat dinyatakan sebagai berikut:

$\left[\right.$ slopekurva indiferen $\left.=-\frac{d y}{d x}=T_{S M_{X, y}}\right]$ 
Dimana:

$d y=$ perubahan jumlah konsumsi barang $y$

$\mathrm{dx}=$ perubahan jumlah konsumsi barang $\mathrm{x}$

4. Konveksitas

Asumsi konveksitas mengandung pengertian bahwa konsumsi yang mengandung kombinasi dua produk lebih disukai daripada mengkonsumsi satu jenis produk saja atau disebut juga konsumsi ekstrim. Apabila konsumen dalam mengkonsumsi kombinasi $P$ dan $Q$ berada dalam kondisi indiferen, maka bias dipastikan konsumen akan mengkonsumsi sebagian produk $\mathrm{Y}$ dan $\mathrm{X}$ daripada seluruhnya produk $Y$ atau seluruhnya produk $X$. Dengan demikian bentuk kurva indiferen sebagaimana ditunjukkan pada Gambar 2.10.

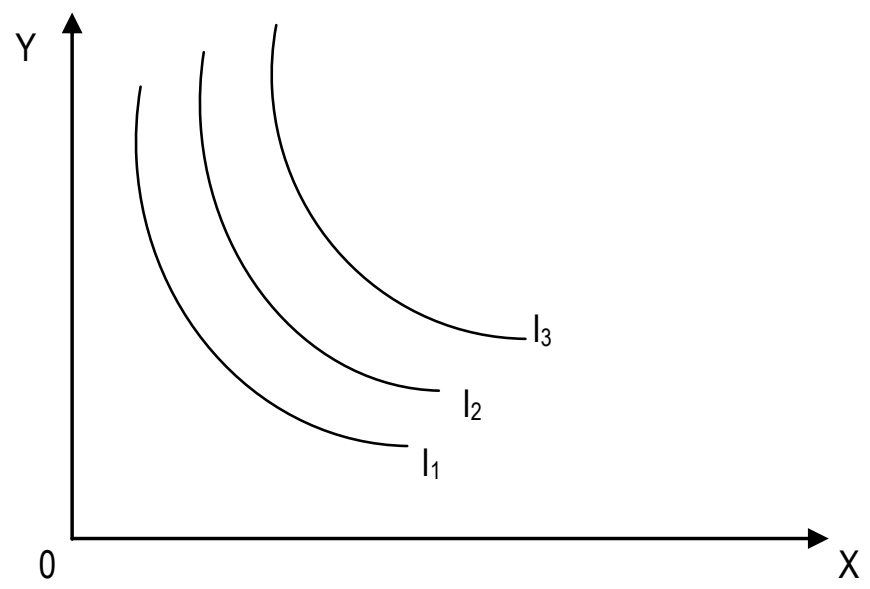

Gambar 2.10.Peta Indiferen

Gambar 2.10.menunjukkan tiga kurva indiferen yang mempunyai tingkat preferensi/kepuasan yang berbeda. Salah satu prinsip yang penting adalah dalam batas-batas tertentu semakin banyak barang yang dikonsumsi maka semakin disukai. Dengan demikian kurva indiferen yang mempunyai jumlah kombinasi barang $X$ dan $Y$ yang lebih banyak akan lebih disukai dan mempunyai tingkat kepuasan yang lebih tinggi. Artinya semakin jauh kurva ini dari titik origin akan semakin disukai. Pada Gambar 2.10 dapat diketahui bahwa semua kombinasi barang $X$ dan $Y$ yang terletak pada kurva idiferen 2 lebih disukai dari semua kombinasi pada kurva indiferen 1. Tetapi sebaliknya semua kombinasi barang $X$ dan $Y$ yang ada pada kurva indiferen 3 , lebih disukai dibandingkan dengan semua kombinasi 
pada kurva indiferen 2.Dengan demikian kombinasi yang paling disukai adalah yang terletak pada kurva indiferen 3 yang berada paling jauh dari titik asal.

5. Total utility tergantung pada jumlah barang yang dikonsumsi

$U=f\left(q_{1}, q_{2}, q_{3} \ldots q_{n}\right)$

Dimana

$\mathrm{U}=$ utlility atau kepuasan

$q=$ komoditas yang dikonsumsi

$\mathrm{n}=$ jumlah jenis komoditas yang akan dikonsumsi

6. Konsistensi dan transitivitas

Konsumen diasumsikan memiliki perilaku yang konsisten dengan pilihannya. Jika pada periode sekarang mereka lebih memilih A dibandingkan $B$, maka pada periode yang lain mereka tidak akan memilih A lebih dulu. Asumsi konsisten dapat difourmulasikan sebagai berikut:

Jika $A \subset B$ maka $B \not \subset A$

Adapun asumsi transivitas adalah sebagai berikut: apabila $A$ lebih disukai dari B dan B lebih disukai dari C, maka dapat dinyatakan bahwa A lebih disukai dari C. Secara simblos dapat dinyatakan:

Jika $\mathrm{A} \supset \mathrm{B}$ dan $\mathrm{B} \supset \mathrm{C}$ maka $\mathrm{A} \supset \mathrm{C}$

\subsubsection{Karakteristik Kurva Indiferen}

1. Slope yang negative

Kurva indiferen mempunyai slope/kemiringan yang negatif. Jika kuantitas dari satu komoditas (misalnya $X$ ) meningkat maka kuantitas komoditas yang lainnya (misalnya $Y$ ) harus menurun untuk mempertahankan konsumen berada pada tingkat kepuasan yang sama.

2. Posisi dari titik asal

Kurva indiferen yang berada pada titik terjauh dari titik asal mempunyai tingkat kepuasan yang paling tinggi. Kombinasi barang $X$ dan $Y$ yang berada pada kurva indiferen terjauh paling disukai oleh konsumen yang rasional. 
3. Tidak pernah saling berpotongan

Kurva indifferent tidak pernah saling berpotongan. Gambar 2.11 menunjukkan bahwa apabila kurva indiferen $I_{1}$ dan $I_{2}$ saling berpotongan, artinya tingkat kepuasan kedua kurva indiferen tersebut adalah sama. Padahal hal tersebut adalah tidak mungkin.

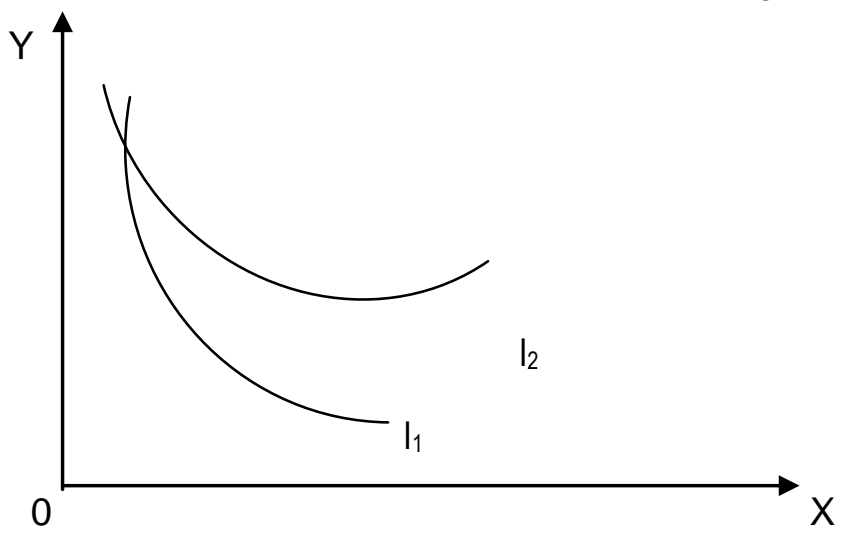

Gambar 2.11.Perpotongan antar Kurva Indiferen

4. Cembung terhadap titik asal

Slope dari kurva indiferen adalah menurun jika kita bergerak dari kiri atas ke arah kanan bawah. Dan juga tingkat substitusi marginal adalah menurun.

\subsubsection{Garis Kendala Anggaran}

Garis kendala anggaran adalah berbagai kombinasi dari dua jenis komoditi yang dapat dibeli oleh konsumen dengan mempertimbangkan tingkat pendapatan dan harga komoditas tersebut. Satu garis anggaran akan menghubungkan titik-titik kombinasi pembelian 2 macam barang yang mengeluarkan anggaran atau pendapatan tertentu.

Apabila kita akan membeli 2 komoditas maka kendala anggaran adalah sebagai berikut:

$$
\mathbf{Y}=\mathbf{P}_{\mathrm{u}} \mathbf{q}_{\mathrm{u}}+\mathbf{P}_{\mathrm{t}} \mathbf{q}_{\mathrm{t}}
$$

Dimana

$$
\begin{aligned}
& Y=\text { Anggaran yang tersedia } \\
& P_{u}=\text { Harga barang } U \\
& q_{u}=\text { Jumlah barang } U \\
& P_{t}=\text { Harga barang } t \\
& q_{t}=\text { Jumlah barang } t
\end{aligned}
$$


Garis anggaran ini diilustrasikan pada gambar 2.12.dengan $U$ sebagai fungsi linier terhadap $\mathrm{T}$, intercept sebesar $\mathrm{Y} / \mathrm{Pu}$ (artinya semua anggaran dipergunakan untuk membeli barang $U$ ), apabila semuanya digunakan untuk membeli $\mathrm{T}$ maka jumlah $\mathrm{T}$ yang terbeli adalah $\mathrm{Y} / \mathrm{P}_{\mathrm{T}}$. Slope atau kemiringan garis anggaran adalah -PT/Pu. Daerah di bawah garis anggaran, menunjukkan kombinasi barang $T$ dan $U$ yaag dapat dibeli oleh seorang konsumen dengan pendapatan yang dimiliki; misalnya titik V. Sedangkan berbagai kombinasi barang $T$ dan $U$ di atas garis anggaran menunjukkan kombinasi yang tidak dapat dibeli oleh konsumen dengan anggaran yang tersedia, contohnya titik W.

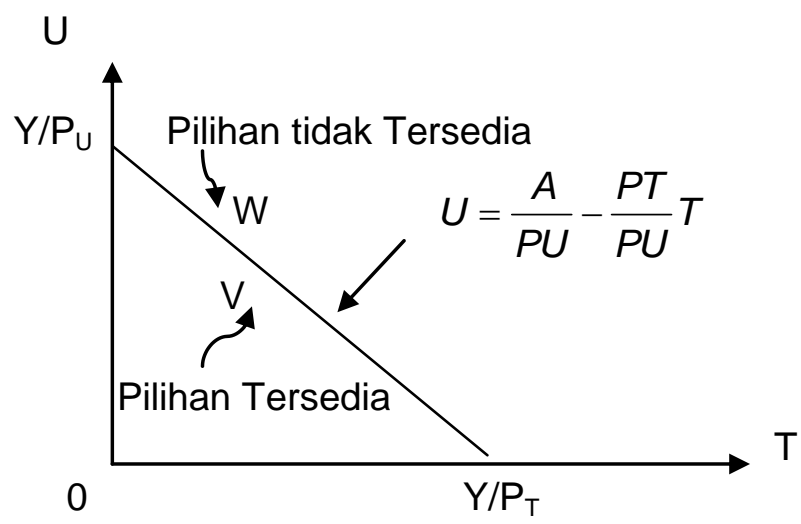

Gambar 2.12.Garis anggaran dan pilihan tersedia

Gambar 2.12.mengasumsikan bahwa harga komoditas tersebut dan pendapatan konsumen tetap tidak berubah. Jika variable-variable tersebut berubah, maka jumlah komoditas yang bias dibeli juga akan berubah. Ada tiga perubahan yang mungkin terjadi: pertama, harga berubah dan pendapatan tetap, kedua, pendapatan berubah dan hargaharga tetap dan ketiga, pendapatan dan harga keduanya berubah. Gambar 2.13, menunjukkan kemungkinan yang pertama, yaitu perubahan harga produk, dengan pendapatan tetap.

Apabila terdapat kondisi dimana harga barang $\mathrm{T}(\mathrm{PT})$ turun dari PT1 menjadi PT2 (PT2<PT1), sedangkan $\mathrm{P}_{\mathrm{u}}$ tetap dan pendapatan tetap. Penurunan harga $\mathrm{T}$ akan menyebabkan kemiringan garis anggaran ( $\mathrm{PT} / \mathrm{Pu})$ semakin kecil, sehingga garis anggarannya semakin 
datar. Akibatnay jumlah maksimum produk $\mathrm{T}$ yang dapat dibeli oleh konsumen semakin banyak (A/PT, $<\mathrm{A} / \mathrm{P}_{\mathrm{T} 2}$ karena $\left.\mathrm{PT} 1>\mathrm{PT} 2\right)$. Sedangkan jumlah maksimum produk $U$ yang dapat dibeli oleh konsumen tidak barubah karena harga $U$ tidak berubah. Jadi penurunan harga $T$ akan memutar garis anggaran keluar seperti yang ditujukkan pada gambar 2.13. Apabila harga T menurun lagi ke PT3 (PT2>PT3) maka garis anggaran akan semakin ke kanan yang mengindikasikan bahwa jumlah $\mathrm{T}$ yang bias dibeli semakin banyak.

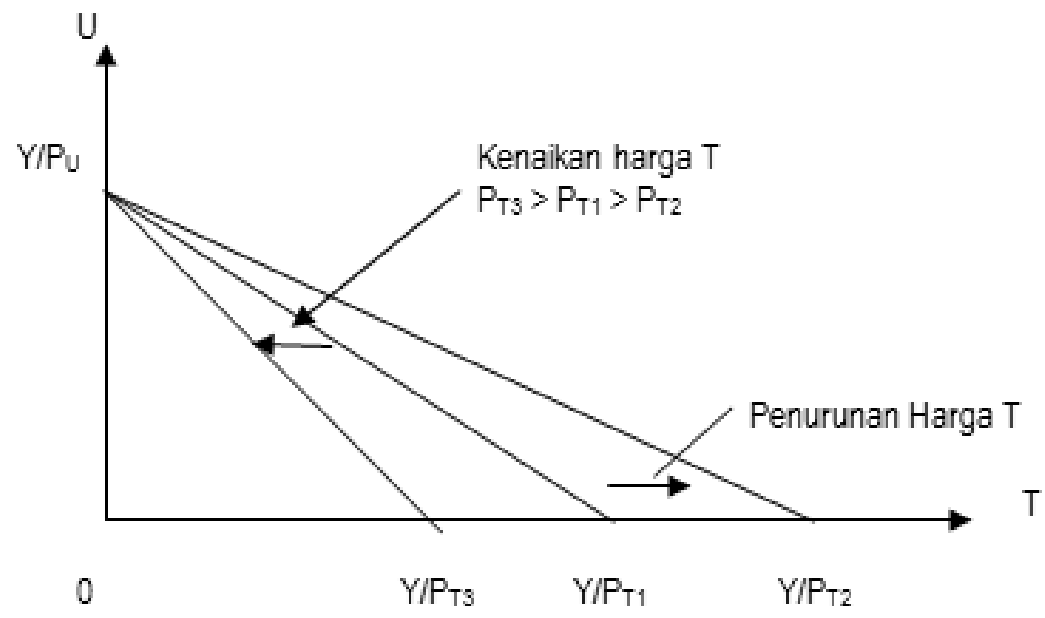

Gambar 2.13. Perubahan Harga Produk

Jika harga $\mathrm{T}$ meningkat menjadi $\mathrm{P}_{\mathrm{T} 3}$ maka yang terjadi adalah sebaliknya $\left(\mathrm{P}_{\mathrm{T}_{3}}>\mathrm{P}_{\mathrm{T}}\right)$. Jumlah maksimum produk $\mathrm{T}$ yang dapat dibeli oleh seorang konsumen akan berkurang $\left(\mathrm{Y}_{/} \mathrm{P}_{\mathrm{T} 1}>\mathrm{Y} / \mathrm{P}_{\mathrm{T} 3}\right.$, karena $\left.\mathrm{P}_{\mathrm{T} 1}<\mathrm{P}_{\mathrm{T} 3}\right)$. Dengan demikian garis anggarannya akan berputar ke dalam seperti yang ditunjukkan pada gambar 2.13. Artinya slope garis anggaran semakin curam.

Kemungkinan kedua yang mungkin terjadi adalah terjadi perubahan pendapatan dengan tingkat harga tetap. Pendapatan konsumen mula-mula adalah $Y_{1}$. Jika pendapatan meningkat menjadi $Y_{2}$ sementara harga produk $\mathrm{T}$ dan $\mathrm{U}$ tetap, apakah yang akan terjadi dengan garis anggaran? Jika harga produk $T$ dan $U$ tetap maka $P_{T} / P_{u}$ yang menunjukkan kemiringan garis anggaran juga tetap. Akan tetapi jumlah maksimum kedua produk yang dibeli oleh konsumen akan meningkat karena naiknya tingkat pendapatan konsumen tersebut. 
Jika pendapatan meningkat dari $Y_{1}$ ke $Y_{2}$, garis anggaran akan bergeser ke kanan sejajar dengan garis anggaran mula-mula. Pergeseran ke kanan menunjukkan semakin banyaknya pilihan yang tersedia bagi konsumen karena semakin banyak produk yang dapat diraih oleh konsumen sebagai akibat dari kenaikan pendapatan. Dan sebaliknya, jika pendapatan konsumen menurun dari $Y_{1}$ sampai $Y_{3}$, dengan harga tetap, maka garis anggaran konsumen akan bergeser ke kiri sejajar dengan garis anggaran mula-mula. Pergeseran ke kiri menunjukkan semakin sedikitnya pilihan tersedia seorang konsumen, karena semakin sedikit produk yang dapat diraih oleh konsumen tersebut.

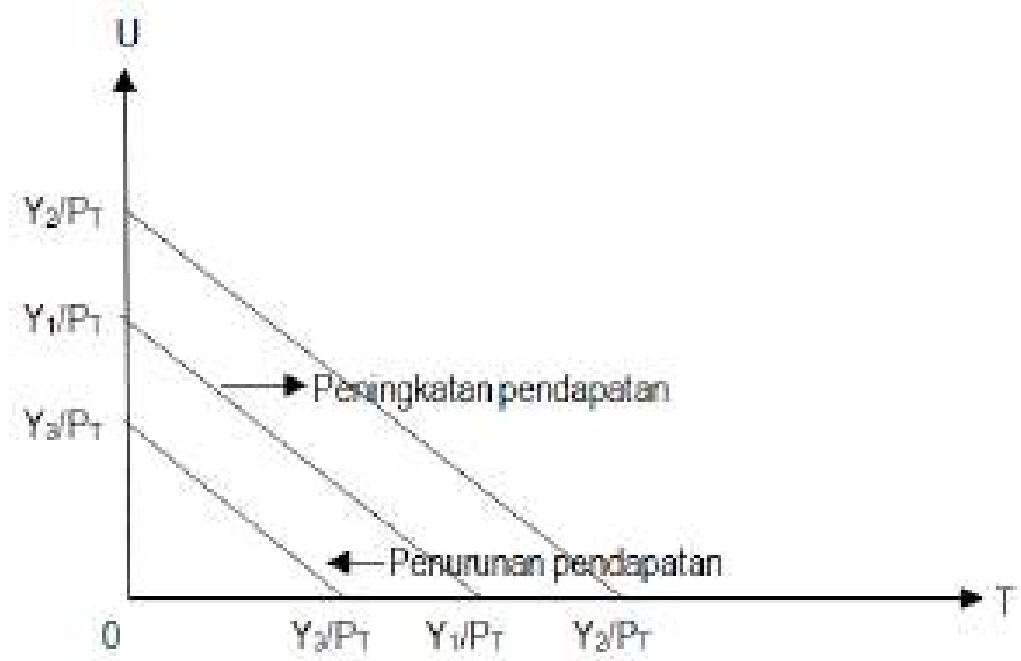

Gambar 2.14. Perubahan Pendapatan akan Menggeser Garis Anggaran

\subsubsection{Keseimbangan Konsumen}

Individu dikatakan berada dalam keadaan equilibrium apabila pada tingkat harga dan pendapatan tertentu, konsumen bisa mencapai tingkat utility atau kepuasan yang maksimal. Atau dengan kata lain, konsumen berada dalam kondisi equilibrium dengan garis anggaran tertentu apabila bisa mencapai kurva indiferen tertinggi yang mungkin dicapai.

Tingkat utility atau kepuasan maksimum tercapai apabila kurva indiferen bersinggungan dengan garis kendala anggaran. Gambar 2.15 menunjukkan bahwa pada tingkat kurva indiferen $\mathrm{I}_{0}$, keseimbangan konsumen tercapai. Sedangkan pada kurva indiferen $I_{1}$ tidak tercapai 
keseimbangan konsumen karena kurva indiferen $I_{1}$ tidak bersinggungan melainkan memotong garis kendala anggaran. Hal ini berarti tingkat kepuasan yang diperoleh masih belum optimal. Pada titik $B$, tingkat kepuasan yang diperoleh adalah $\mathrm{I}_{1}$, hal ini belum optimal karena masih ada dibawah garis anggaran yang artinya konsumen bisa menambah konsumsinya untuk mendapatkan tingkat kepuasan yang lebih tinggi. Sedangkan pada titik $\mathrm{C}$, kurva indiferen yang dicapai adalah $\mathrm{I}_{2}$ dimana berada diatas garis kendala anggaran. Hal ini berarti jumlah anggaran yang tersedia tidak mencukupi untuk membeli barang sehingga tercapai tingkat kepuasan $\mathrm{I}_{2}$.

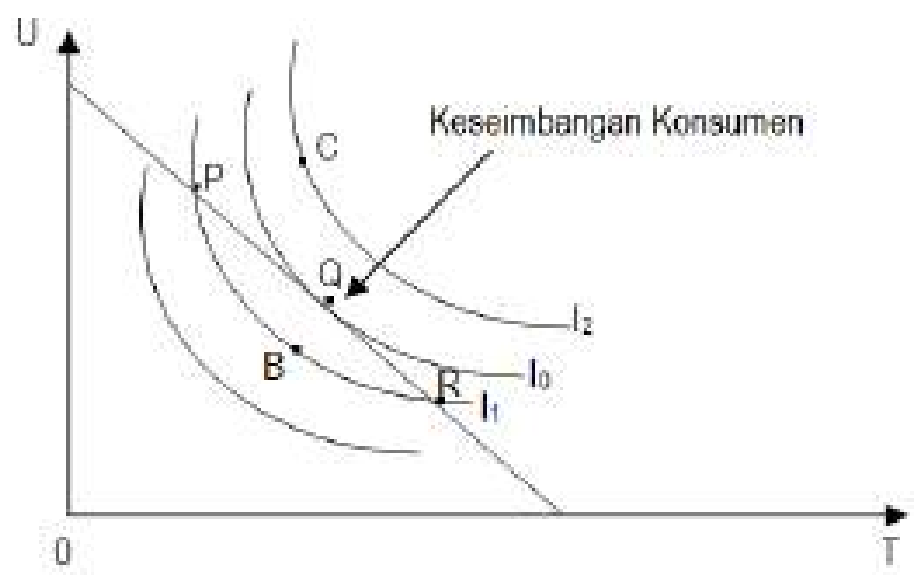

Gambar 2.15. Keseimbangan Konsumen

Kurva indiferen menggambarkan bagaimana selera konsumen. Sesuai dengan teori yang ada yang menyatakan semakin banyak barang yang dikonsumsi semakin disukai, maka seseorang konsumen akan berusaha untuk mencapai kurva indiferen yang tinggi, karena hal ini akan memberikan kombinasi produk yang paling banyak. Namun terdapat satu hal yang membatasi seseorang konsumen hanya dapat mencapai kurva indiferen tertentu yaitu garis anggaran. Dengan anggaran tertentu yang dimiliki, konsumen akan berusaha mencapai kurva indiferen yang paling tinggi.

Gambar 2.15. menunjukkan bahwa titik $P, Q$ dan $R$ semuanya berada pada garis kendala anggaran. Hal ini berarti bahwa titik-titik tersebut menghabiskan seluruh anggaran yang dimiliki konsumen. Dan konsumen tidak dapat lagi membeli barang melebihi kombinasi tersebut. Dari ketiga titik tersebut Kombinasi Q memberikan kepuasan yang lebih tinggi bagi konsumen dibandingkan kombinasi $P$ dan $R$ 
karena terletak pada kurva indiferen yang lebih tinggi yaitu $I_{0}$. Namun demikian ombinasi $Q$ masih dapat dijangkau oleh konsumen karena masih berada pada garis anggaran. Dengan demikian jika konsumen memilih kombinasi $\mathrm{P}$ daripada $\mathrm{Q}$, maka konsumen itu bertindak tidak efesien, karena dengan anggaran yang sama, kombinasi $P$ memberikan kepuasan yang lebih rendah yang ditandai dengan tingkat capaian yang hanya pada kurva $I_{1}$.

Gambar 2.15 juga menunjukkan hubungan antara produk $T$ dan $U$ yang saling bersubtitusi. Keseimbangan berubah dari titik $B$ ke titik $P$ yang berimplikasi pada kenaikan jumlah konsumsi produk $U$, tetapi jumlah konsumsi T menurun. Sedangkan jika hubungan antara produk $T$ dan $\mathrm{U}$ berkomplemen, keseimbangan konsumen berubah dari titik B ke titik Q. Jumlah konsumsi produk T dan produk $U$, keduanya bertambah.

Pergeseran keseimbangan konsumen juga akan terjadi sebagai akibat perubahan harga barang yang dikonsumsi. Jika harga produk berubah, maka garis anggaran konsumen akan berubah sehingga akhirnya keseimbangan konsumen juga akan berubah. Gambar 2.16 menjelaskan fenomena tersebut. Penurunan harga akan menggeser titik intersept barang tersebut dengan garis anggaran ke kanan sedangkan kenaikan harga akan menggeser garis anggaran ke sebelah kiri. Misalnya harga $T$ menurun dari $\mathrm{P}_{\mathrm{T} 1}$ menjadi $\mathrm{P}_{\mathrm{T} 2}$ maka garis anggaran berputar keluar. Pilihan tersedia bagi konsumen semakin banyak, sehingga konsumen juga memperoleh kepuasan yang lebih tinggi. Hal ini ditunjukkan oleh titik $Q$ yang terletak pada kurva indiferen yang lebih tinggi.

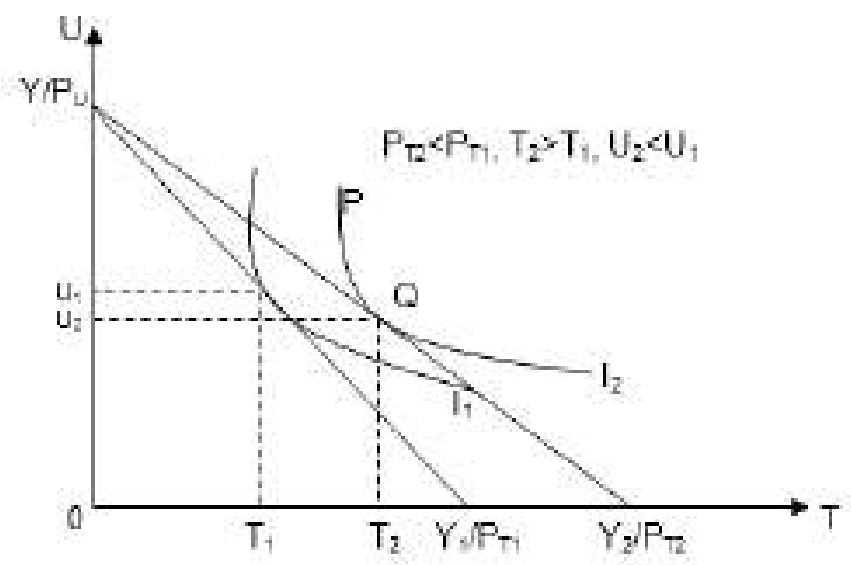

Gambar 2.16. Penurunan Harga T ( $U$ adalah subsitusi T) 
Keseimbangan konsumen sepanjang garis kendala anggaran yang baru tergantung pada selera konsumen dan hubungan antara kedua produk. Saling bersubtitusi atau berkomplemen. Jika T dan U saling bersubtitusi, maka kenaikan (penurunan) harga $T$ akan mengakibatkan kenaikan (penurunan) jumlah produk $U$ yang diminta. Jika $\mathrm{T}$ dan $\mathrm{U}$ saling berkomplemen, maka kenaikan (penurunan) harga $\mathrm{T}$ akan menurunkan (menaikkan) jumlah produk $U$ yang diminta.

Selanjutnya akan dibahas tentang pengaruh perubahan pendapatan terhadap keseimbangan konsumen yang terjadi. Disamping tergantung terhadap naik turunnya tingkat pendapatan, keseimbangan konsumen juga tergantung pula pada jenis barang yang dikonsumsi. Apakah bersifat normal atau inferior.

Gambar 2.17 menunjukkan keseimbangan konsumen berubah dari titik $\mathrm{P}$ ke titik $\mathrm{Q}$, karena kenaikan pendapatan. Konsumsi untuk produk $\mathrm{T}$ dan $\mathrm{U}$ meningkat, yang berarti bahwa kedua produk itu adalah produk normal.

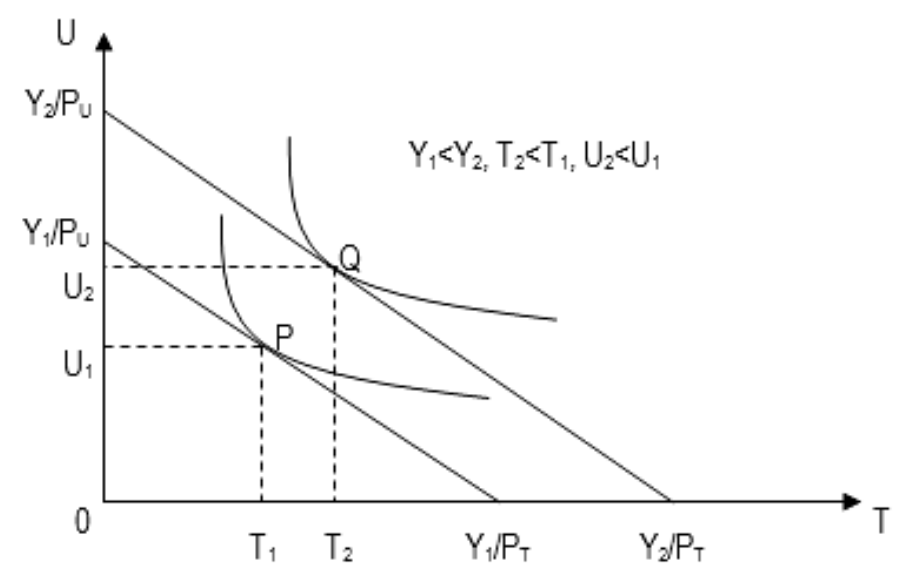

Gambar 2.17. Peningkatan Pendapatan (T dan $U$ adalah barang normal)

Gambar 2.18 menunjukkan hal yang berbeda, produk $\mathrm{T}$ adalah inferior dan produk $U$ normal. Kenaikan pendapatan membuat keseimbangan konsumen beralih dari titik $\mathrm{W}$ ke titik $\mathrm{T}$, dimana konsumsi makan $(U)$ meningkat tetapi konsumsi produk rumah $(T)$ menurun. Jika terjadi penurunan pendapatan, permintaan rumah akan meningkat dari $\mathrm{R}$, menjadi $\mathrm{R}_{2}$.Konsumsi akan makan yang mungkin adalah antara daerah U-W. Dimisalkan di titik W. Jadi konsumsi makan akan menurun. Maka makan haruslah produk normal. 


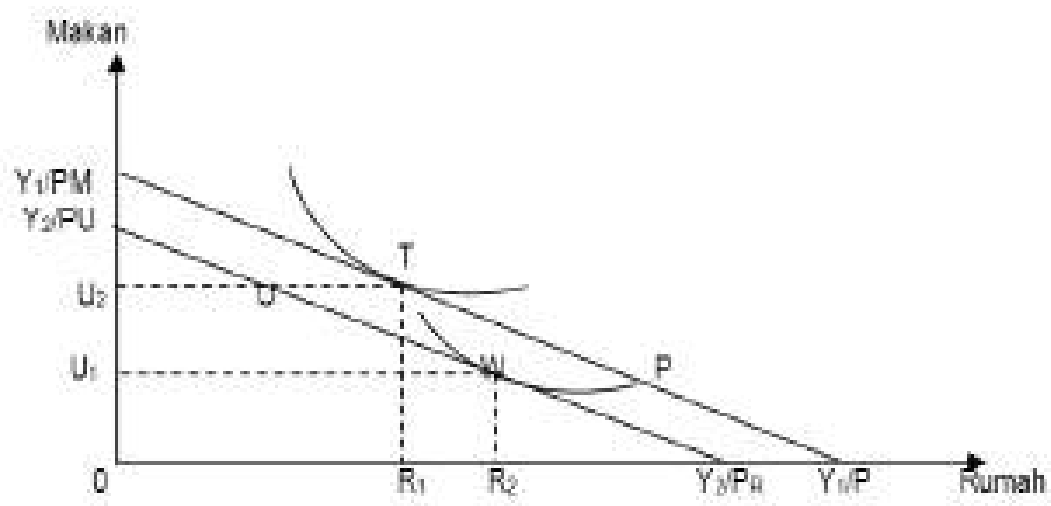

Gambar 2.18. Makan (U) adalah Barang Normal dan Rumah (T) barang inferior

Jika makan adalah produk normal, maka ketika terjadi penurunan pendapatan, permintaan untuk makan akan turun. Keseimbangan konsumsi mula-mula adalah di titik $\mathrm{T}$ dengan konsumsi makan sebesar M. Keseimbangan konsumen setelah penurunan pendapatan haruslah terletak antara U-W. Dalam hal ini terdapat dua kemungkinan. Jika Keseimbangan berada di titik $W$, berarti rumah adalah produk normal. Tetapi jika keseimbangan konsumen berada di titik X, maka rumah adalah produk inferior (Gambar 2.19).

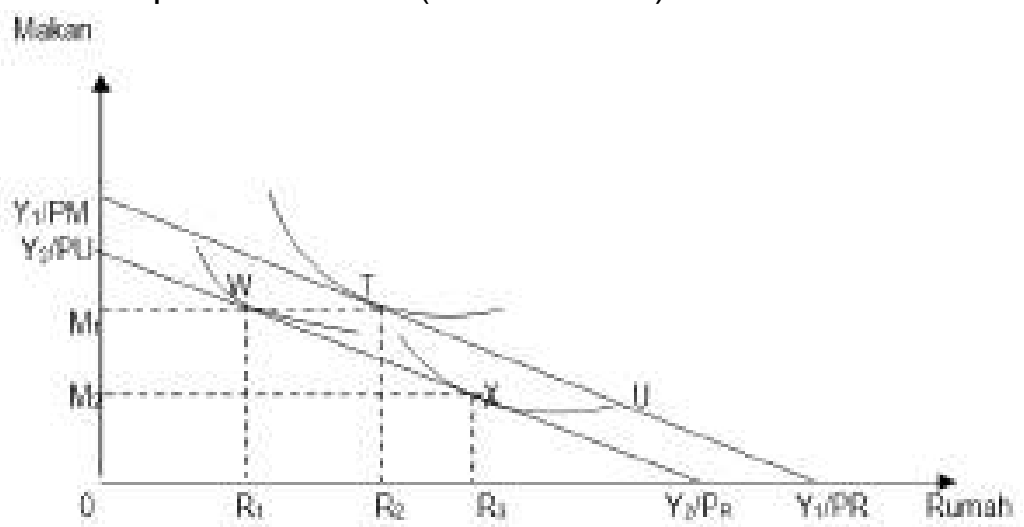

Gambar 2.19. Rumah Produk Inferior atau Normal

\subsubsection{Kurva Konsumsi-Pendapatan dan Kurva Engel}

Kurva konsumsi-pendapatan dan kurva Engel bisa diperoleh dari perubahan pendapatan konsumen dengan mempertahankan harga barang dan selera tetap konstan. Adapun definisi dari kurva konsumsi- 
pendapatan adalah kombinasi titik-titik equilibrium konsumen yang dihasilkan pada berbagai tingkat pendapatan. Gambar 2.20 menunjukkan kurva konsumsi pendapatan dan kurva Engel. Sedangkan kurva Engel memperlihatkan jumlah komoditi yang ingin dibeli konsumen per periode waktu tertentu pada berbagai tingkat pendapatan total konsumen.

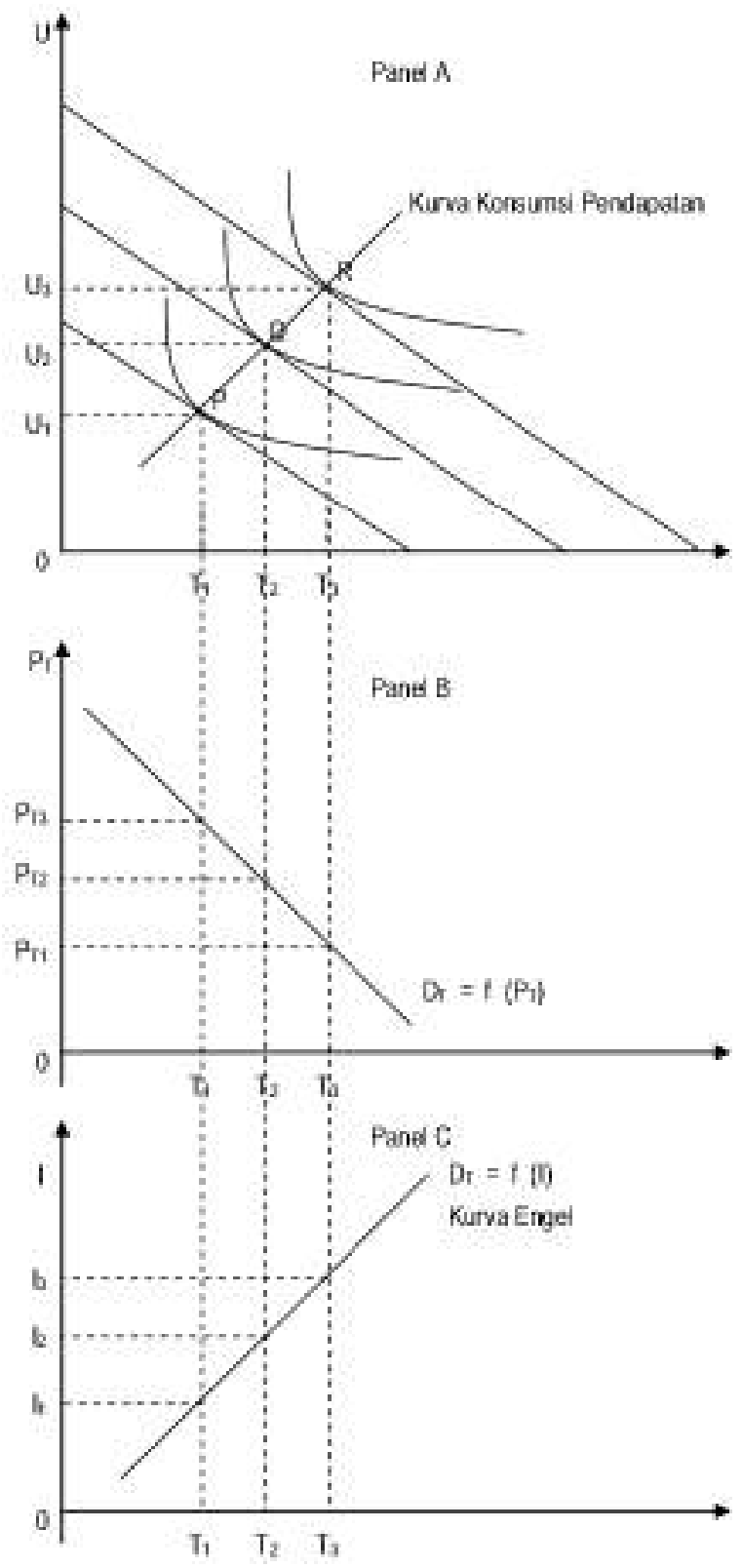

Gambar 2.20. Kurva Konsumsi Pendapatan dan Kurva Engel 
Gambar 2.20 panel A mengilustrasikan tiga titik keseimbangan konsumen $\mathrm{P}, \mathrm{Q}$ dan $\mathrm{R}$ pada berbagai tingkat pendapatan. Dari gambar tersebut dapat diketahui bahwa tingkat konsumsi barang dan jasa akan meningkat apabila pendapatan konsumen meningkat.

Selanjutnya panel B menjelaskan hubungan antara jumlah barang yang dikonsumsi dan harga. Grafik yang dihasilkan adalah kurva permintaan terhadap barang T. Dari gambar tersebut diketahui bahwa apabila harga barang turun maka jumlah barang yang diminta akan naik.

Panel C menunjukkan proses pembentukan kurva Engel yang menunjukkan hubungan antara jumlah barang yang diminta dan tingkat pendapatan konsumen. Jika tingkat pendapatan konsumen meningkat maka jumlah barang yang diminta akan meningkat pula.

\subsubsection{Surplus Konsumen}

Surplus konsumen (consumer's surplus) menggambarkan suatu keuntungan lebih atau surplus yang dinikmati konsumen tertentu yang membeli suatu barang pada tingkat harga tertentu. Sebagaimana diketahui fungsi permintaan adalah $P=f(Q)$ menunjukkan jumlah suatu barang yang bersedia dibeli oleh individu pada tingkat harga tertentu. Apabila harga barang tersebut telah ditetapkan maka sebagian konsumen sebenarnya mau dan mampu membayar lebih besar dari harga tersebut. Selisih antara kemauan konsumen membayar dengan harga pasar adalah keuntungan lebih dari konsumen yang biasanya disebut surplus konsumen.

Gambar 2.21. menunjukkan bahwa fungsi permintaan dan penawaran membentuk harga keseimbangan sebesar $P_{e}$. Sesungguhnya konsumen mau dan mampu membayar lebih dari $P_{\mathrm{e}}$ untuk mendapatkan barang $Q$ sebanyak $Q_{\mathrm{e}}$. Selisih antara kemampuan dan kemauan konsumen untuk membayar dengan $\mathrm{P}_{\mathrm{e}}$ adalah surplus konsumen. Dalam hal ini, surplus konsumen adalah luas area dibawah kurva permintaan tetapi di atas tingkat harga pasar atau area $\mathrm{P}_{\mathrm{e}} \mathrm{AB}$. 


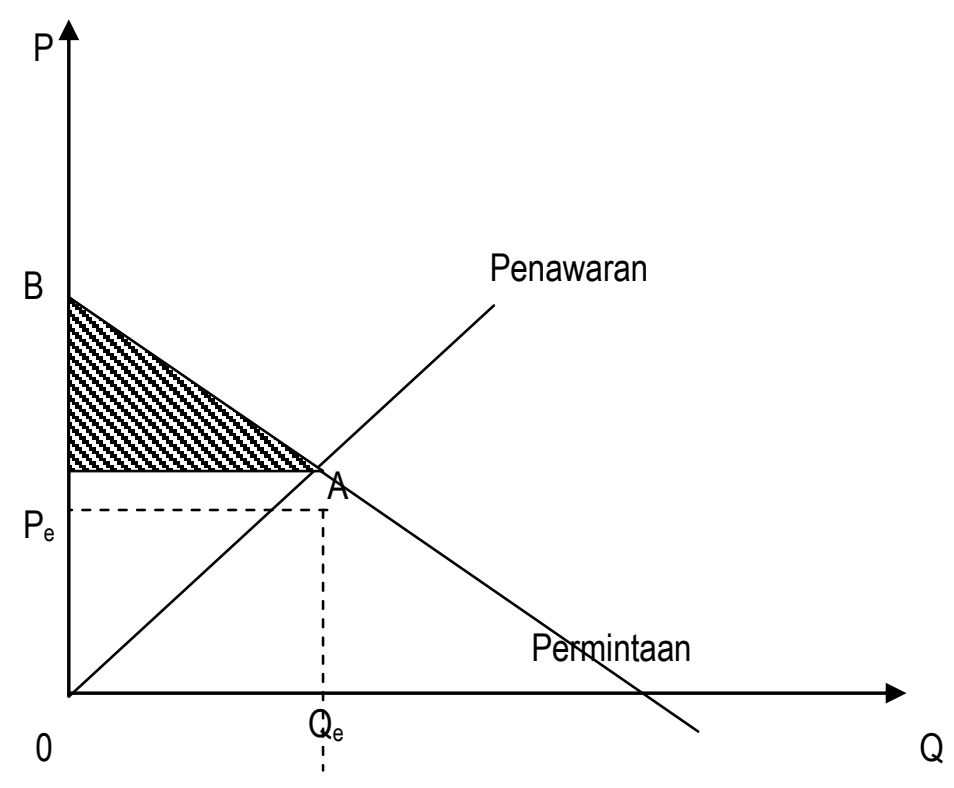

Gambar 2.21. Surplus Konsumen

\subsubsection{Surplus Produsen}

Surplus produsen (producer's surplus) menjelaskan suatu profit lebih atau surplus yang diterima oleh produsen tertentu berkaitan dengan tingkat harga pasar suatu barang yang ditawarkan. Sama dengan surplus konsumen, fungsi penawaran $P=f(Q)$ merepresentasikan jumlah barang yang akan dijual oleh produsen pada tingkat harga tertentu.

Gambar 2.22 mengilustrasikan surplus yang diterima oleh produsen. Jika tingkat harga pasar adalah $\mathrm{P}_{\mathrm{e}}$, maka bagi produsen yang sebenarnya bersedia menjual dengan harga yang lebih rendah dari $P_{e}$, maka produsen tersebut akan mendapatkan kelebihan profit atau surplus. Hal tersebut menjadi keuntungan bagi produsen sebab kini mereka menjual dengan harga yang lebih tinggi dari yang direncanakan. Keuntungan lebih inilah yang disebut surplus konsumen.

Pada gambar 2.22.surplus ditunjukkan oleh luas area di atas kurva penawaran tetapi dibawah tingkat harga pasar. Surplus produsen tak lain adalah segitiga $\mathrm{P}_{\mathrm{e}} \mathrm{AC}$. 


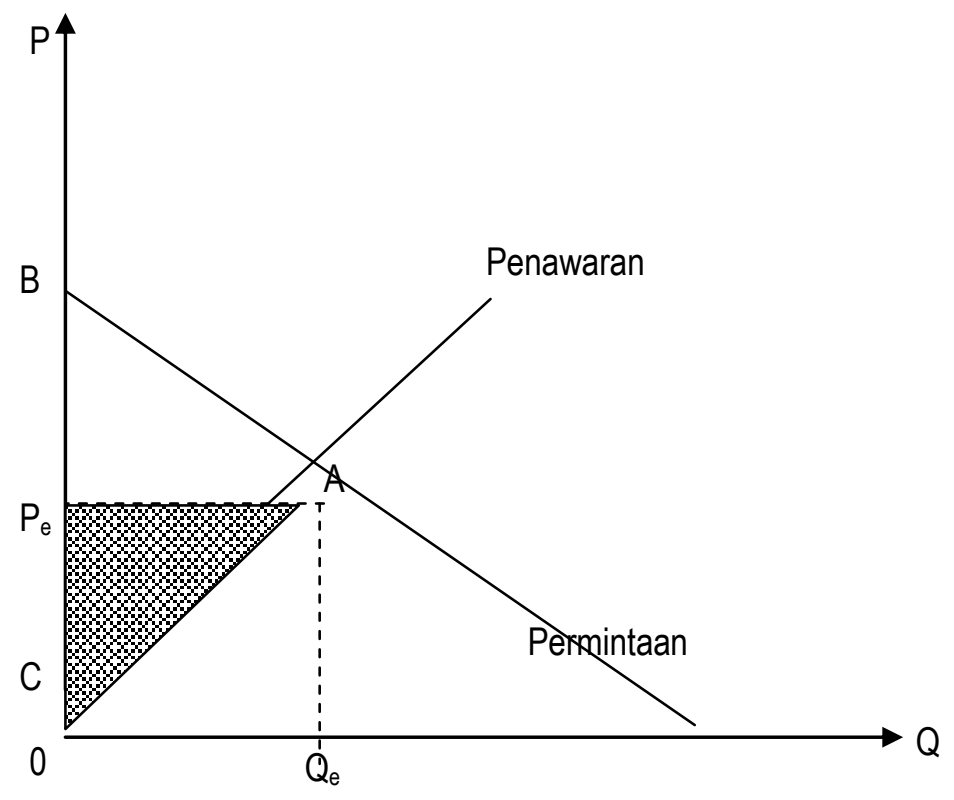

Gambar 2.22. Surplus Produsen

\subsection{Latihan Soal}

1. Nyatakan secara matematis fungsi permintaan suatu barang!

2. 2.Tabel di bawah ini menunjukkan perubahan konsumsi individu atas kopi dan teh ketika harga kopi naik ceteris paribus.

a. Buatlah gambar yang menjelaskan perubahan tersebut!

b. Jelaskan gambar tersebut dan kaitkan dengan sifat hubungan antara kedua jenis barang tersebut (substitusi atau komplementer ?)!

\begin{tabular}{|l|c|c|c|c|}
\hline \multirow{2}{*}{ Komoditi } & \multicolumn{3}{|c|}{ Perubahan harga dan jumlah yang dikonsumsi } \\
\cline { 2 - 5 } & \multicolumn{2}{|c|}{ Sebelum } & \multicolumn{2}{c|}{ Sesudah } \\
\cline { 2 - 5 } & $\begin{array}{c}\text { Harga } \\
\text { (Rp/gelas) }\end{array}$ & $\begin{array}{c}\text { Jumlah } \\
\text { konsumsi } \\
\text { (gelas/bulan) }\end{array}$ & $\begin{array}{c}\text { Harga } \\
\text { (Rp/gelas) }\end{array}$ & $\begin{array}{c}\text { Jumlah } \\
\text { konsumsi } \\
\text { (gelas/bulan) }\end{array}$ \\
\hline Kopi & 40 & 50 & 60 & 30 \\
\hline Teh & 20 & 40 & 20 & 50 \\
\hline
\end{tabular}


3. Dari fungsi persamaan $Q_{D}=12-2 P$, selesaikan soal dibawah ini:

a. Skedul permintaan individu!

b. Gambarkan kurva permintaan individu!

c. Berapakah jumlah permintaan maksimum yang dihasilkan dari fungsi permintaan yang disebutkan diatas?

4. Jelaskan pernyataan dibawah ini. Bila perlu gunakan grafik!

a. Perubahan jumlah yang diminta.

b. Perubahan permintaan

5. Apa yang dimaksud dengan barang normal, inferior dan superior?

6. Perhatikan skedul total utility (TU) dibawah ini. Kemudian selesaikan perintah dibawah ini:

a. Carilah skedul marginal utility (MU) dan average utility (AU).

b. Gambarkan grafiknya!

c. Tunjukkan titik jenuhnya!

\begin{tabular}{|c|c|c|c|c|c|c|c|c|c|c|}
\hline $\mathrm{Q}$ & 0 & 1 & 2 & 3 & 4 & 5 & 6 & 7 & 8 & 9 \\
\hline $\mathrm{TU}$ & 0 & 7 & 13 & 18 & 22 & 25 & 27 & 28 & 28 & 27 \\
\hline
\end{tabular}

7. Tabel dibawah ini menunjukkan titik kombinasi penggunaan dua jenis output dari empat kurva kepuasan sama pada sepasang sumbu yang sama

a. Gambarkan kurva kepuasan sama I,II,III dan IV

b. Dari gambar yang anda buat, sebutkan ciri-ciri dari kurva kepuasan sama

\begin{tabular}{|c|c|c|c|c|c|c|c|}
\hline \multicolumn{2}{|c|}{ I } & \multicolumn{2}{|c|}{ II } & \multicolumn{2}{c|}{ III } & \multicolumn{2}{c|}{ IV } \\
\hline$Q_{X}$ & $Q_{Y}$ & $Q_{X}$ & $Q_{Y}$ & $Q_{X}$ & $Q_{Y}$ & $Q_{X}$ & $Q_{Y}$ \\
\hline 2 & 13 & 3 & 12 & 5 & 12 & 7 & 12 \\
\hline 3 & 6 & 4 & 8 & 5.5 & 9 & 8 & 9 \\
\hline 4 & 4.5 & 5 & 6.3 & 6 & 8.3 & 9 & 7 \\
\hline 5 & 3.5 & 6 & 5 & 7 & 7 & 10 & 6.3 \\
\hline 6 & 3 & 7 & 4.4 & 8 & 6 & 11 & 5.7 \\
\hline 7 & 2.7 & 8 & 4 & 9 & 5.4 & 12 & 5.3 \\
\hline
\end{tabular}

8. Apakah mungkin dua kurva kepuasan sama mempunyai bentuk dan hubungan seperti gambar dibawah ini? Jelaskan! 


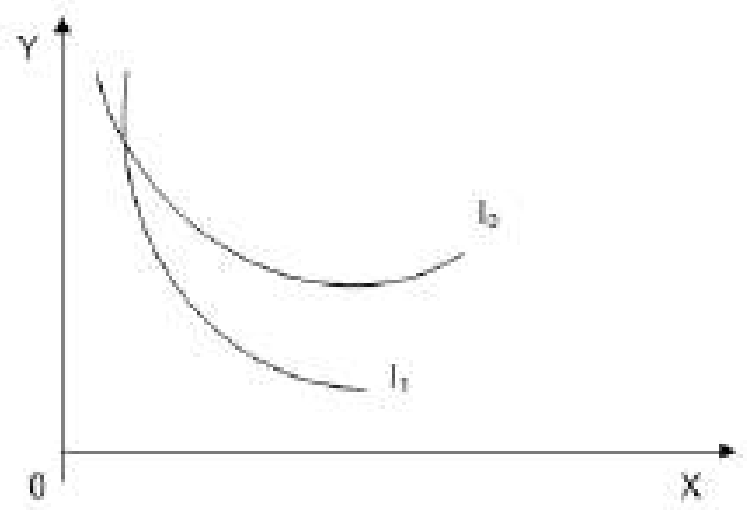

9. Misalkan harga komoditi $Y$ adalah $\$ 1$ per unit dan harga komoditi $X$ adalah \$2 per unit dan misalkan bahwa pendapatannya adalah sebesar $\$ 16$. Semua pendapatan tersebut dibelanjakan untuk membeli barang $\mathrm{X}$ dan $\mathrm{Y}$.

a. Gambarlah garis kendala anggaran berdasarkan data yang ada!

b. Berdasarkan gambar di atas, jelaskan sifat dan karakteristik dari garis kendala anggaran!

10. Jika kurva kepuasan konsumen direpresentasikan oleh kurva indiferen pada Soal no 7 dan pendapatan serta kendala anggaran konsumen ditunjukkan pada soal no 9

a. Gambar dan jelaskan pada titik mana konsumen mencapai kondisi equilibrium!

b. Mengapa pada titik tersebut terjadi kondisi equilibrium konsumen? Kaitkan jawaban anda dengan kemiringan kurva indiferen dan slope garis anggaran.

11. Teori permintaan berkaitan erat dengan konsep kurva konsumsi pendapatan dan kurva Engel

a. Jelaskan definisi dari kedua konsep tersebut!

b. Gambarkan secara geometris langkah-langkah untuk mendapatkan kurva konsumsi pendapatan dan kurva engel.

\section{Istilah - istilah Penting ;}

Jumlah yang diminta

Ceteris paribus

Hukum perimintaan 


\section{BAB 3 \\ TEORI PENAWARAN}

\section{TUJUAN INSTRUKSIONAL KHUSUS}

1. Mahasiwa dapat menjelaskan pengertian penawaran

2. Mahasiwa mampu menerangkan bagaimana terjadinya kurva penawaran

3. Mahasiswa mampu menjelaskan dan menunjukkan bagaiman terjadinya pergeseran dan pergerakan kurva penawaran

\subsection{Penawaran Suatu Barang}

Penawaran suatu barang diartikan sebagai jumlah barang yang diprduksi dan dijual oleh produsen kepada konsumen. Penawaran suatu barang (hasil produksi) dari produsen kepada konsumen dipengaruhi oleh banyak faktor, faktor-faktor tersebut antara lain:

1. Harga barang itu sendiri,

2.Harga dari masukan-masukan (input),

3. Teknologi,

4. Pajak,

5. Cuaca/iklim dan lain sebagainya.

Sehingga apabila dibuat dalam suatu persamaan matematis adalah sbb ;

$$
Q_{s x}=f\left(P_{x}, P_{y}, P_{z}, \ldots \ldots . P_{i t}, T, T_{x}, C, \ldots \ldots \ldots \ldots\right) .
$$

Dimana:

Qsx = Jumlah barag $x$ yang ditawarakan .

$P x=$ Harga barang itu sendiri (barang $X$ )

$P y=$ Harga barang lain yang terkait.

Pz, Pit, ......... P, = Harga faktor - faktor produksi (input)

$T=$ Teknologi

$\mathrm{Tx}=$ Pajak

$\mathrm{C}=$ Cuaca / iklim dan lain sebagainya. 
Berdasarkan faktor-faktor yang mempengaruhi penawaran suatu barang, harga barang itu sendiri adalah yang paling berpengaruh. Dengan mengganggap faktor lain tidak berubah (ceteris paribus), fungsi penawaran suatu barang dapat dituliskan sebagai berikut:

\section{Qsx $=\mathbf{f}(P x)$, Ceteris paribus}

Berdasarkan fungsi penawaran tersebut, kita akan mendapatkan skedul penawaran. Skedul penawaran akan suatu barang menunjukkan antara harga pasar dari suatu barang tersebut dengan jumlah barang yang akan diproduksi dan dijual (ditawarkan), ceteris paribus. Untuk lebih memahami dari penjelasan di atas, maka dapat dilihat contoh berikut:

Tabel 3. 1. Skedul Penawaran Barang $X$

\begin{tabular}{|c|c|c|}
\hline Kondisi & $\begin{array}{c}\text { Harga (Rp. /unit) } \\
\text { Jumlah yang ditawarkan (unit per } \\
\text { tahun) } \\
(\mathrm{Qx})\end{array}$ \\
\hline $\mathrm{A}$ & $(\mathrm{Px})$ & 120 \\
$\mathrm{~B}$ & 10 & 90 \\
$\mathrm{C}$ & 8 & 60 \\
$\mathrm{D}$ & 6 & 30 \\
$\mathrm{E}$ & 4 & 0 \\
\hline
\end{tabular}

Dari Tabel 3. 1. dapat dijelaskan bahwa pada harga Rp. 10,jumlah barang yang ditawarkan 120 unit, pada harga Rp. 8,- jumlah yang ditawarkan 90 unit, dan pada harga Rp. 6,- jumlah yang ditawarkan 60 unit, dan seterusnya. Apabila data-data tersebut digambarkan pada suatu grafik, maka grafiknya akan nampak sebagi berikut:

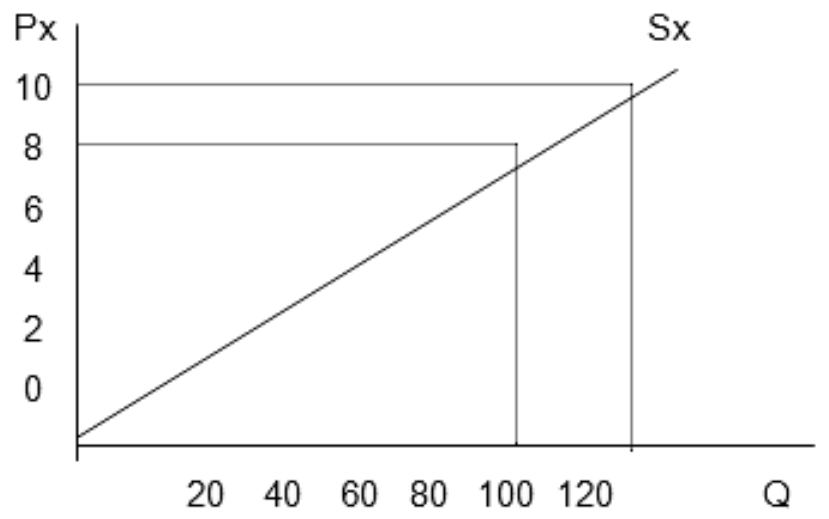

Gambar 3.1. Kurva Penawaran Suatu Barang 
Mengapa kurva penawaran suatu barang pada pada umumnya bergerak dari kiri bawah ke kanan atas?. Alasan yang utama adalah karena hukum pertambahan hasil yang semakin berkurang (the law of diminishing return), karena produsen menawarkan produknya kepada konsumen adalah berorientasi pada suatu keuntungan bukan kesenangan atau amal sodaqoh dan amal jariyah. Produsen akan menyukai harga yang lebih tinggi dan menawarkan produknya lebih banyak.

Kita mengetahui bahwa kurva penawaran mempunyai kemiringan (slope) yang positif. Slope yang positif ini merupakan kondisi yang umum untuk kurva penawaran. Dalam kondisi tertentu kurva penawaran tidak mempunyai slope positif. Beberapa kasus tertsebut antara lain adalah:

1. Kasus perusahaan menghendaki harga barang tetap, dalam kasus ini perusahaan dapat menawarkan suatu barang dengan jumlah yang lebih banyak dengan harga tetap.

2. Kasus Penawaran yang tetap, ada beberapa jumlah barang atau faktor diproduksi yang jumlahnya terbatas. Dengan demikian berapapun harganya yang ditawarkan tetap tidak akan berubah.

3. Kasus penawaran yang melengkung kebelakang atau memiliki slope negatif (backward bending supply). Kasus ini biasanya terjadi pada pasar tenaga kerja, apabila pada tingkat upah tertentu, penawaran tenaga kerja akan menurun pada saat tingkat upah naik. Pada titik upah tertentu tenaga kerja tersebut akan menggunakan waktunya untuk bersantai karena upah yang diterimanya dianggap cukup.

\subsection{Penawaran Pasar Suatu Barang}

Penawaran pasar suatu barang adalah penjumlahan secara horisontal penawaran-penawaran perusahaan secara individual akan barang tersebut. Dalam suatu industri ada kemungkinan terdapat banyak produsen. Sikap masing-masing produsen terhadap suatu pasar bisa berbeda-beda, hal ini disebabkan karena biaya per unit yang dikeluarkan oleh masing-msing perusahaan tidak sama karena tingkat efisiensi masing-masing perusahaan adalah berbeda.

Untuk harga pasar tertentu, mungkin perusahaan $A$ akan menawarkan $\mathrm{X}$ unit, tetapi perusahaan $\mathrm{B}$ menawarkan $\mathrm{y}$ unit, dan perusahaan $\mathrm{C}$ akan mewarkan $\mathrm{Z}$ unit, dan seterusnya. Dengan demikian pada harga tertentu jumlah yang ditawarkan oleh produsen secara keseluruhan merupakan penjumlahan dari jumlah yang ditawarkan masing-masing produsen secara keseluruhan merupakan penjumlahan 
dari jumlah yang ditawarkan oleh masing-masing produsen tersebut. Penjumlahan penawaran-penawaran produsen secara individual tersebut dinamakan "penawaran pasar". Penawaran suatu pasar ditentukan oleh semua faktor yang menentukan penawaran produsen secara individu.

Sebagai bahan ilustrasi maka dapat digunakan informasi sebagi berikut: apabila dalam suatu industri hanya terdapat 3 produsen (produsen $A, B$, dan $C$ ) masing-masing memiliki penawaran sebagai berikut:

Tabel 3.2.Skedul Penawaran di Suatu Industri

\begin{tabular}{|c|c|c|c|}
\hline Harga per Kg & Penawaran A & Penawaran B & Penawaran C \\
\hline Rp. $2000,-$ & $2.000 \mathrm{Kg}$ & $1.000 \mathrm{Kg}$ & $1.500 \mathrm{Kg}$ \\
Rp. $1.000,-$ & $1.200 \mathrm{Kg}$ & $800 \mathrm{Kg}$ & $1.000 \mathrm{Kg}$ \\
\hline
\end{tabular}

Penawaran masing-masing perusahaan apabila dilihat dengan suatu gambar maka akan nampak seperti gambar berikut:

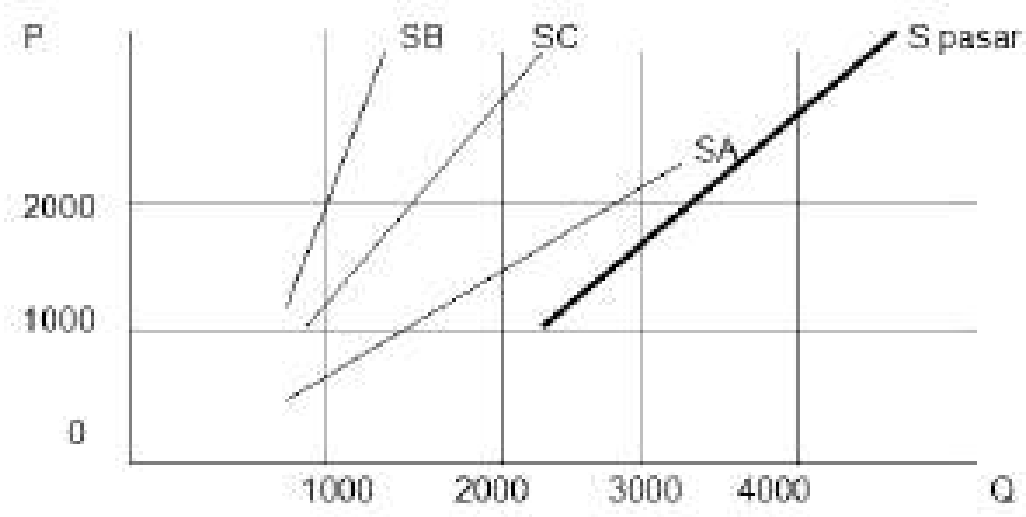

Gambar 3.2.Penawaran Perusahaan

Sedangkan apabila untuk mengetahui permintaan pasar maka dapat dilihat pada tabel berikut:

Tabel 3.3. Skedul Penawaran Individual dan Penawaran Pasar

\begin{tabular}{|c|c|c|c|c|}
\hline Price / Kg & Supply A & Supply B & Supply C & Market Supply \\
\hline Rp. 2.000 & $2.000 \mathrm{Kg}$ & $1.000 \mathrm{Kg}$ & $1.500 \mathrm{Kg}$ & $4.500 \mathrm{Kg}$ \\
Rp. 1.200 & $1.000 \mathrm{Kg}$ & $800 \mathrm{Kg}$ & $1.000 \mathrm{Kg}$ & $3.000 \mathrm{Kg}$ \\
\hline
\end{tabular}




\subsection{Pengaruh Non Harga terhadap Penawaran}

Dalam penentuan kurva, hal yang sangat mendasar untuk diketahui sehubungan dengan perilaku penawaran bisnis adalah bahwa produsen menawarkan komoditas untuk tujuan laba atau keuntungan dan bukan untuk tujuan lain. Unsur utama yang mendasari kurva penawaran adalah biaya produksi. jika biaya produksi relatif rendah terhadap pasar, maka penawaran produk akan banyak menguntungkan produsen, dan begitu pula sebaliknya. Biaya produksi ini banyak dipengaruhi oleh harga input dan teknologi. Harga input (tenaga kerga, energi, atau mesin) memiliki pengaruh yang sangat penting pada biaya produksi pada sejumlah kuantitas produksi tertentu.

Tabel 3. 4. Faktor yang Mempengaruhi Penawaran Suatu Barang

\begin{tabular}{|l|l|}
\hline $\begin{array}{l}\text { Faktor yang menentukan } \\
\text { kurva penawaran }\end{array}$ & \multicolumn{1}{|c|}{ Contoh } \\
\hline 1. Teknologi & $\begin{array}{l}\text { Pembuatan barang diproses dengan } \\
\text { komputer akan menurunkan biaya } \\
\text { produski dan meningkatkan penawaran }\end{array}$ \\
\hline 2.Harga Input & $\begin{array}{l}\text { Penurunan suku bunga pinjaman akan } \\
\text { menurunkan biaya produks dan } \\
\text { meningkatkan penawaran }\end{array}$ \\
\hline 3. Harga barang terkait & $\begin{array}{l}\text { Peningkatan harga indomie rebus rasa } \\
\text { ayam bawang akan menurunkan } \\
\text { penawaran indomie rebus rasa lain dan } \\
\text { indomie goreng. }\end{array}$ \\
\hline 4. Kebijakan pemerintah & $\begin{array}{l}\text { Keikutsertaan Indonesia dalam AFTA } \\
\text { akan meningkatkan ekspor kenegara } \\
\text { anggota AFTA }\end{array}$ \\
\hline 5. Pengaruh khusus & $\begin{array}{l}\text { Adanya keyakinan perubahan harga di } \\
\text { masa yang akan datang mempengaruhi } \\
\text { penawaran. }\end{array}$ \\
\hline
\end{tabular}

Sumber: Endang Setiyowati dkk, 2000

Faktor penentu lain terhadap biaya produksi adalah kemajuan teknologi, dimana kemajuan teknologi mengakibatkan penurunan kebutuhan input yang dibutuhkan untuk menghasilkan sejumlah kuantitas yang sama. Hal ini dapat dimungkinkan misalnya oleh karena temuan 
teknologi terapan yang menyederhanakan atau mempersingkat aliran kerja.

\subsection{Perubahan Penawaran}

Bisnis mengubah secara konstan baik produk barang dan jasa yang mereka tawarkan. Penawaran akan berubah jika hal-hal yang mempengaruhi terhadap komuditas juga berubah. Dalam bentuk kurva penawaran, kita mengatakan bahwa penawaran yang meningkat (menurun) jika jumlah yang ditawarkan meningkat (menurun) pada setiap harga pasar.

Kita dapat memberikan gambaran pregeseran penawaran terhadap pasar sebagaimana diilustrasikan pada Gambar 3. 3.

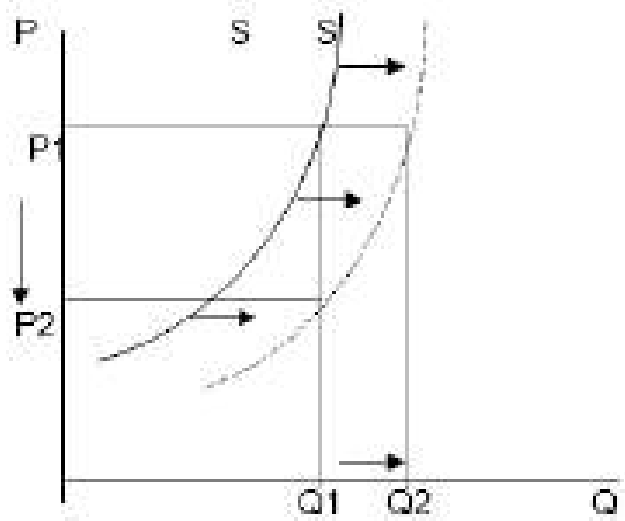

Gambar 3.3. Pergeseran Penawaran

Gambar 3.3. Memberikan ilustrasi tentang peningkatan penawaran produk $Q$. mula-mula pada harga $P 1$ jumlah produk $Q$ yang ditawarkan adalah sebanyak Q1, setelah kurva penawaran bergeser ke kanan bawah, pada harga sama (P1) jumlah yang ditawarkan meningkat menjadi Q2.Pada jumlah $Q$ yang ditawarkan tetap, produsen bersedia menawarkan harga yang lebih rendah yaitu P2.Hal ini berarti terjadi penurunan harga.

Selain bergeser kekanan bawah, kurva penawaran juga bergeser ke kiri atas. Dengan demikian pada harga yang sama produsen menawarkan barang dalam jumlah yang lebih sedikit. Berdasarkan kedua irisan ini dapat disimpulkan bahwa perubahan penawaran tidak 
disebabkan oleh perubahan harga barang yang bersangkutan, tetapi oleh faktor-faktor yang semula dianggap tetap.

\subsection{Perubahan Jumlah yang Ditawarkan}

Misalkan pada suatu saat terjadi kenaikan harga (ceteris paribus) suatu produk $Q$ untuk kota $A$. kenaikan harga ini mendorong para produsen untuk menambah jumlah produk yang akan dijual serta mendorong produsen lain untuk menjual produk yang serupa di kota $A$ tersebut. Dengan demikian produk $Q$ yang dijual pada kota $A$ menjadi naik. Kenaikan jumlah produk $Q$ yang ditawarkan tersebut disebabkan oleh kenaikan produk $Q$ bukan penyebab lain, misal penurunan bahan baku $Q$.

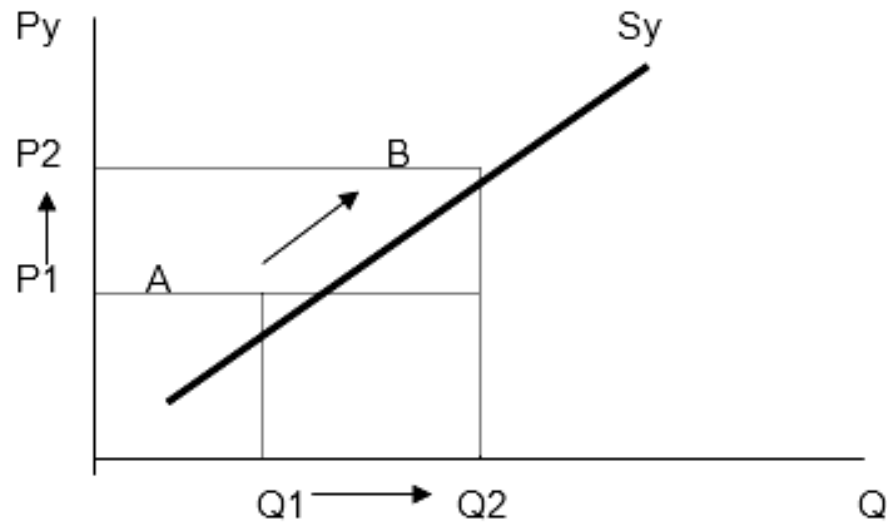

Gambar 3.4. Kurva Perubahan Jumlah Penawaran

Dari gambar 3.4. di atas dapat dijelaskan pada harga per unit barang $Y$ setinggi $P 1$ jumlah barang $Y$ yang ditawarkan sebanyak $Q 1$. Kenaikan harga dari P1 menjadi P2 mengakibatkan kenaikan jumlah barang $Y$ yang ditawarkan mengalami kenaikan dari Q1 menjadi Q2.Peningkatan jumlah suatu barang yang diwarkan sebagai respon atau tanggapan atas kenaikan harga apabila dinyatakan pada kurve penawaran akan menunjukkan pergerakan kombinasi harga dan jumlah suatu barang yang ditawarkan disepanjang kurve penawaran. Hal ini berbeda dengan kenaikan penawaran pada setiap harga atau kenaikan penawaran pada harga yang sama. Ini berarti kenaikan penawaran tidak disebabkan oleh kenaikan barang yang bersangkutan, tetapi oleh faktor lain yang mempengaruhi penawaran. 


\subsection{Latihan Soal}

1. Apa yang dimaksud dengan penawaran suatu barang? Faktor-faktor apa saja yang mempengaruhi penawaran suatu barang?

2. Diketahui fungsi penawaran $Q_{S}=20 P$

a. Buatlah skedul penawaran dengan melengkapi tabel di bawah ini

b. Buatlah kurva penawaran berdasarkan hasil pada point (a)

c. Apa saja yang harus dipertahankan konstan dalam fungsi penawaran tersebut?

\begin{tabular}{|c|c|c|c|c|c|c|c|}
\hline $\mathrm{P}$ & 6 & 5 & 4 & 3 & 2 & 1 & 0 \\
\hline $\mathrm{Q}_{\mathrm{s}}$ & & & & & & & \\
\hline
\end{tabular}

3. Berdasarkan data dibawah ini buatlah

a. Kurva penawaran individu

b. Kurva penawaran pasar

c. Berdasarkan point (a) dan (b), apa yang bisa anda simpulkan?

\begin{tabular}{|c|c|c|c|}
\hline Harga per Kg & Penawaran A & Penawaran B & Penawaran C \\
\hline Rp. $2000,-$ & $1.000 \mathrm{Kg}$ & $2.000 \mathrm{Kg}$ & $1.500 \mathrm{Kg}$ \\
Rp. $1.000,-$ & $750 \mathrm{Kg}$ & $1.100 \mathrm{Kg}$ & $1.000 \mathrm{Kg}$ \\
\hline
\end{tabular}

4. Pada umumnya kemiringan kurva penawaran adalah positif. Namun ada kasus-kasus tertentu kurva penawaran mempunyai slope negatif. Jelaskan pernyataan di atas!

5. Fungsi penawaran produsen semula adalah $Q_{S}=-40+20 P$. Akibat adanya kemajuan teknologi, fungsi penawaran produsen berubah menjadi $Q_{S}=-10+20 P$

a. Buatlah skedul penawaran produsen sebelum dan sesudah adanya kemajuan teknologi dengan mengisi table dibawah ini!

b. Pada satu grafik, gambarlah 2 kurva penawaran produsen berdasarkan data pada point (a)!

c. Berapa banyak komoditi $X$ yang ditawarkan produsen pada harga $\$ 4$ sebelum dan sesudah adanya kemajuan teknologi?

\begin{tabular}{|c|c|c|c|c|}
\hline $\mathrm{P}$ & 8 & 4 & 2 & 0.5 \\
\hline $\mathrm{Q}_{\text {sebelum }}$ & & & & \\
\hline $\mathrm{Q}_{\text {sesudah }}$ & & & & \\
\hline
\end{tabular}

Istilah - istilah Penting ;

Penawaran

Jumlah yang ditawarkan

Beckward bending supply 


\section{BAB 4 \\ KESEIMBANGAN PASAR}

\section{TUJUAN INSTRUKSIONAL KHUSUS}

1. Mahasiswa dapat menjelaskan arti keseimbangan pasar

2. Mahasiswa dapat menghitung pergeseran keseimbangan pasar

3. Mahasiswa dapat mengilustrasikan pergeseran permintaan dan penawaran

4. Mahasiswa dapat menjelaskan kebijakan harga dasar dan harga maksimum

\subsection{Arti Keseimbangan Pasar}

Konsumen membutuhkan suatu barang untuk memenuhi kebutuhan hidupnya dan produsen menawarkan suatu barang yang dihasilkan. Produsen dan konsumen bertemu di "pasar". Pertemuan antara produsen dan konsumen yang menghasilkan suatu kesepakatan harga dan jumlah barang yang ditransaksikan disebut dengan keseimbangan pasar. Keseimbangan pasar adalah keadaan yang menunjukkan baik konsumen maupun produsen telah menyetujui harga akan suatu barang, yaitu harga yang konsumen bersedia membeli sama dengan harga yang produsen bersedia menjual untuk sejumlah barang tersebut.

Kita mengetahui jumlah yang ingin dibeli dan dijual pada setiap harga. Kita telah melihat bahwa jumlah suatu barang yang diminta merupakan fungsi harga per unit barang yang bersangkutan (ceteris paribus). Demikian jumlah barang yang ditawarkan suatu barang tergantung harga per unit barang terkait (ceteris paribus). Yang jadi masalah adalah bagaimana menyatukan kedua sisi (penawaran dan permintaan) akan suatu barang di pasar yang sama.

Jawaban atas permasalahan di atas adalah terjadinya interaksi antara permintaan dan penawaran untuk menghasilkan harga dan kuantitas keseimbangan, atau keseimbangan pasar. Keseimbangan pasar terjadi pada harga dan kuantitas dalam kondisi kekuatan permintaan dan penawaran dalam keseimbangan. Pada harga 
keseimbangan, jumlah yang ingin dibeli oleh pembeli tepat dengan jumlah yang ingin dijual oleh seorang penjual. Alasan disebut keseimbangan adalah jika permintaan dan penawaran dalam keseimbangan, tidak ada alasan terjadinya kenaikan atau penurunan harga, ceteris paribus. Secara grafis harga keseimbangan dan kuantitas keseimbangan dihasilkan oleh perpotongan antara kuva permintaan (D) dan penawaran (S) di suatu titik. Selanjutnya titik perpotongan ini disebut sebagai titik keseimbangan. Untuk lebih jelasnya dapat dilihar pada gambar berikut:

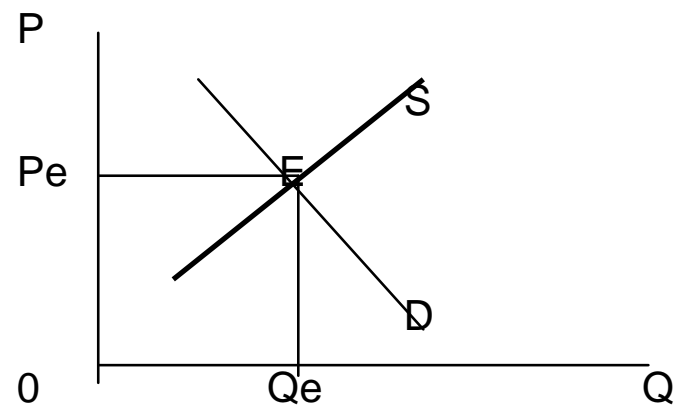

Gambar 4. 1. Kurva Keseimbangan

Titik Pe disebut dengan harga keseimbangan karena untuk jumlah barang sebanyak Qe konsumen sanggup membayar $\mathrm{Pe}$ dan produsen sanggup atau bersedia menawarkan (menjual) dengan harga Pe. Dengan demikian Pe disebut harga keseimbangan untuk sejumlah barang Qe. Sedangkan Qe disebut kuantitas keseimbangan karena pada harga Pe konsumen bersedia membeli sebanyak Qe dan produsen bersedia menawarkan barang sebanyak Qe. Harga dan kuantitas keseimbangan hanya terjadi pada Pe dan Qe.

Keseimbangan atau equlibrium permintaan dan penawaran terjadi pada titik E. perpotongan antara kurve permintaan dan penawaran terjadi pada titik ini, dengan harga barang $X$ setinggi Rp. 6 per unit dan kuantitas $X$ sebanyak 60 unit, kuantitas yang diminta sama dengan kuantitas yang ditawarkan; tidak terjadi kelebihan penawaran dan permintaan; tidak ada kecenderungan harga naik atau turun.

Contoh matematis diuarikan di bawah ini; misalkan persamaan permintaan dan penawaran $\mathrm{Qdx}=50-5 \mathrm{P}$ dan $\mathrm{Qsx}=10+3 \mathrm{P}$. pada 
keseimbangan pasar Qdx = Qsx. Cara mendapatkan harga dan kuantitas adalah sebagai berikut:

$\begin{array}{ll}\text { Qdx } & =50-5 P \\ \text { Qsx } & =10+3 P \\ 50-5 P & =10+3 P \\ 8 P & =40 \\ P & =5 \\ \text { Qdx } & =50-5(5)=25 \\ \text { Qsx } & =10+3(5)=25\end{array}$

Andaikan $\mathrm{P}$ tidak sama dengan 5 , misalnya 4, kita akan dapatkan jumlah barang yang ditawarkan dan yang diminta tidak sama, yaitu 30 dan 22. Hasil perhitungan tersebut menujukkan bahwa jika harga tidak sebesar harga keseimbangan pasti tidak terjadi keseimbangan. Contoh uraian grafis dan matematis menujukkan hasil yang sama, yaitu adanya kelebihan jumlah yang ditawarkan dan kelebihan jumlah yang diminta. Bukti:

$\begin{array}{ll}\text { Qdx } & =50-5(4)=30 \\ \text { Qsx } & =10+3(4)=22\end{array}$

Adapun pembuktian secara grafik dapat dilihat pada Gambar 4.2.dibawah ini.

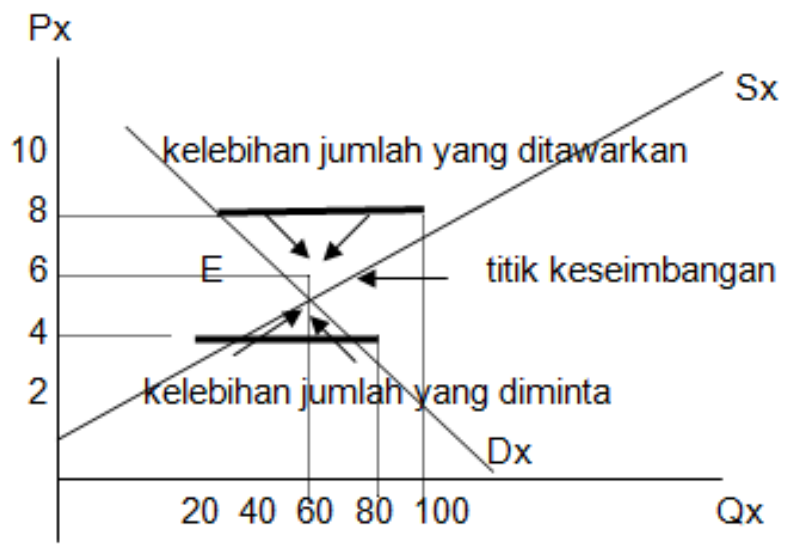

Gambar 4. 2.Posisi Keseimbangan Suatu Penawaran dan Permintaan 


\subsection{Pergeseran Permintaan atau Penawaran}

Analisis permintaan dan penawaran secara bersama-sama dapat memberikan informasi kepada kita tentang keseimbangan harga dan kuantitas. Analisis ini juga dapat untuk memprediksi dampak perubahan kondisi perekonomian terhadap harga dan kuantitas.

Misalkan barang $Y$ merupakan subtitusi yang sangat kuat terhadap barang $X$. jika harga barang $Y$ turun, ada kecenderungan konsumen barang $X$ akan mengganti barang dengan barang $Y$. Dengan demikian pada harga barang $X$ yang sama, permintaan barang $X$ akan turun. Penurunan ini akan mengakibatkan kelebihan penawaran. Kelebihan penawaran akan mengakibatkan produsen menurunkan harga. Penurunan harga ini akan mendorong konsumen untuk meningkatkan kembali jumlah barang $X$ yang diminta. Secara grafis kondisi tersebut dapat ditunjukkan oleh gambar sebagai berikut:

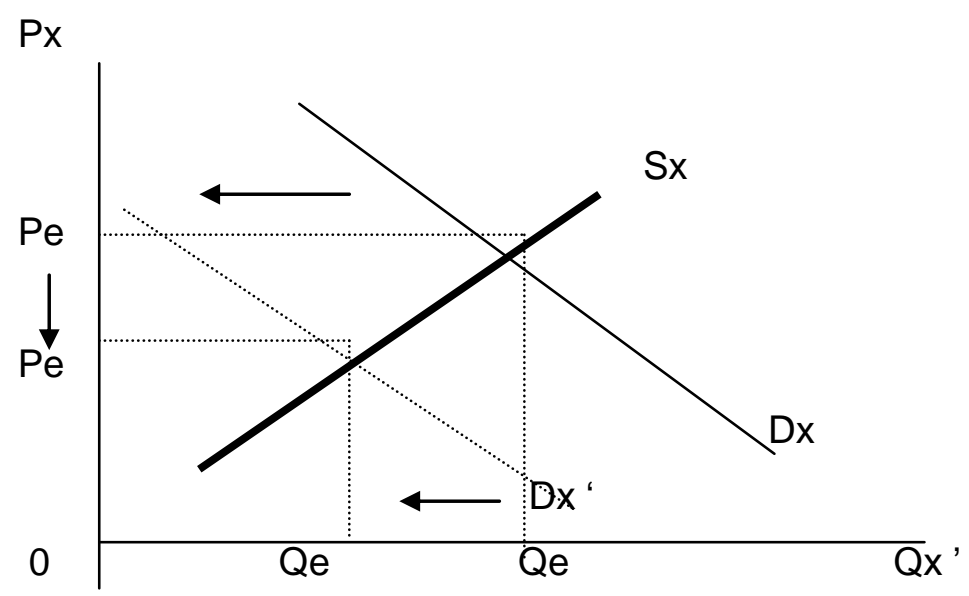

Gambar 4. 3. Pergeseran Kurva Permintaan

Pergeseran kurva permintaan dapat terjadi akibat perubahan faktor lain selain harga barang yang bersangkutan. Misalkan harga faktor barang produski barang $X$ turun. Penurunan harga ini akan meningkatkan penawaran barang $X$ pada setiap harga per unit barang $X$. kondisi semacam ini akan mengakibatkan kelebihan penawaran. Dengan kelebihan penawaran maka produsen akan cenderung menurunkan harga. Penurunan harga ini akan mendorong konsumen membeli produk 
$X$ dalam jumlah yang lebih banyak. Kondisi semacam ini dapat ditunjukkan pada gambar berikut:

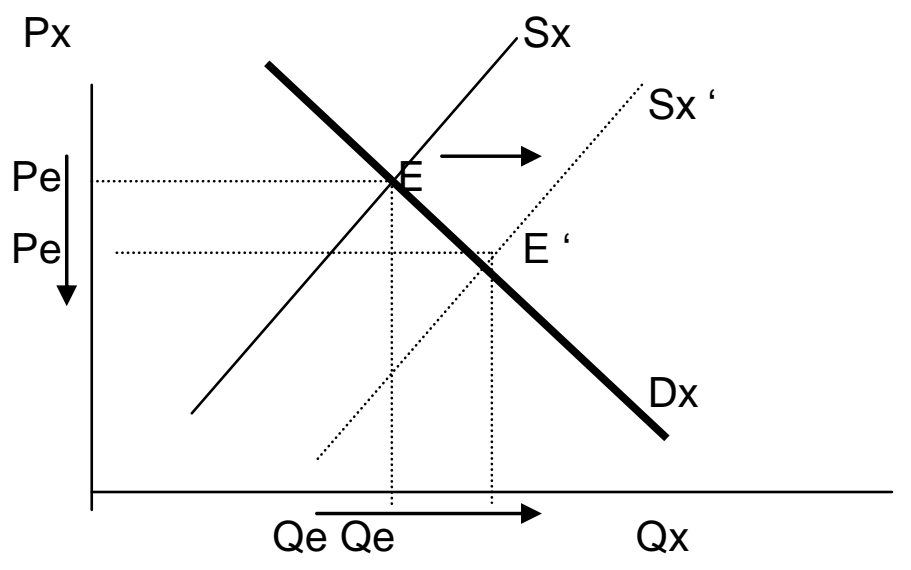

Gambar 4. 4. Pergeseran Permintaan Akibat Faktor Selain Harga

\subsection{Kebijakan Harga Dasar dan Harga Maksimum}

Sehubungan dengan beberapa jenis barang yang diproduksi yang dikonsumsi oleh masyarakat banyak, pemerintah selalu menetapkan harga dasar dan harga maksimum. Secara umum kebijakan ini dapat dikatakan untuk stabilisasi harga (pangan). Harga dasar adalah harga dasar yang tidak dapat dilampaui. Harga yang rendah disebabkan terlau banyak penawaran yang terjadi, harga yang sangat rendah dapat mengakibatkan produsen rugi. Apabila produsen ini sangat banyak dan sangat lemah maka pemerintah berkewajiban melindungi mereka dengan cara menetapkan harga dasar. Dengan demikian penetapan harga dasar adalah untuk melindungi produsen agar tidak mengalami kerugian. Selain itu untuk memberikan semangat kepada produsen agar tetap bersedia memproduksi barang tersebut.

Kebalikan harga dasar adalah harga maksimum. Harga maksimum adalah harga yang tertinggi yang tidak dapat dilampaui. Kondisi ini disebabkan oleh sedikitnya jumlah penawaran yang dilakukan oleh produsen. Hal ini tentunya sangat merugikan konsumen. Apabila konsumen tersebut berjumlah banyak dan lemah, maka pemerintah berkewajiban melindungi mereka dengan cara menetapkan kebijakan harga maksimum. 


\subsection{Latihan Soal}

1. Persamaan permintaan dan penawaran adalah $Q d x=30-5 P$ dan $\mathrm{Qsx}=6+3 \mathrm{P}$. Pada kondisi equilibrium $\mathrm{Qdx}=\mathrm{Qsx}$. Carilah harga dan kuantitas barang pada kondisi equilibrium!

2.Terdapat 10.000 individu yang identik dalam pasar untuk komoditi $X$, masing-masing dengan fungsi permintaan $\mathrm{Qdx}=12-2 \mathrm{Px}$ dan 1.000 produsen komoditi $X$ yang identik, masing-masing fungsi penawarannya adalah $Q s x=20 P x$

a. Carilah fungsi permintaan pasar dan fungsi penawaran pasar untuk komoditi X

b. Carilah skedul permintaan pasar dan penawaran pasar untuk komoditi $\mathrm{X}$ dan cari pula harga dan jumlah equilibriumnya!

c. Gambarkanlah pada satu grafik, kurva permintaan dan penawaran dan tentukan titik equilibriumnya

d. Secara matematik, carilah harga dan jumlah equilibrium

\begin{tabular}{|c|c|c|}
\hline Px & Qdx & Qsx \\
\hline 6 & & \\
\hline 5 & & \\
\hline 4 & & \\
\hline 3 & & \\
\hline 2 & & \\
\hline 1 & & \\
\hline 0 & & \\
\hline
\end{tabular}

\section{Istilah - istilah Penting ;}

Keseimbangan

Excess Demand

Excess Supply

Harga dasar

Harga Maksimum

Stabilisasi harga. 


\section{BAB 5 \\ ELASTISITAS}

\section{TUJUAN INSTRUKSIONAL KHUSUS}

1. Mahasiswa menerangkan maksud, pengertian dan kegunaan elastisitas

2. Mahasiswa mampu menghubungankan jenis-jenis elastisitas yang ada

3. Mahasiswa dapat menjelaskan keterkaitan elastisitas dengan keadaan yang sebenarnya

4. Mahasiswa dapat mengukur elastisitas

\subsection{Pengertian Elastisitas}

Elastisistas merupakan suatu indeks (bilangan) yang menggambarkan hubungan kuantitatif antara variabel dependen dengan variabel independen. Dengan demikian elastisistas dapat didefinisikan sebagai: prosentase perubahan variabel dependen sebagai akibat perubahan variabel independen sebesar satu persen. Apabila semisal definisi ini diterapkan pada kasus permintaan, maka definisi ini akan berbunyi: prosentase prubahan jumlah barang yang diminta (Q) sebagai akibat perbahan harga barang $(P)$ sebesar satu persen. Berdasarkan uraian di atas secara umum dapat dikatakan bahwa elastisitas adalah bilangan (indeks) yang menggambarkan hubungan sebab akibat antara variabel dependen dengan variabel independen.

Walaupun memiliki kemiripan dengan slope, koefisien arah atau gradient suatu garis, elastisitas tidak sama dengan slope. Dengan kata lain elastisitas tidak mengandung nilai seperti rupiah, kilogram, atau liter. Karena sifat tersebut maka elastisitas dapat diterapkan pada berbagai kasus. Misalnya pada kasus permintaan disebut dengan elastisitas permintaan, pada kasus pendapatan disebut dengan elastisitas pendapatan, pada kasus penawaran disebut degan elastisitas penawaran, dan antara kasus dua barang disebut dengan elastisitas silang. 


\subsection{Manfaat Elastisitas}

Elastisitas dapat digunakan untuk mengetahui derajat "kepekaan" variabel dependen terhadap variabel independen. Permintaan suatu barang dikatakan elastis (peka atau sensitif terhadap perubahan harga per unit barang yang bersangkuatan) apabila prosentase perubahan jumlah barang yang diminta lebih besar dari pada prosentase perubahan harga yang dilakukan oleh produsen. Sedangkan elastisitas permintaan suatu barang dikatakan inelastis (tidak peka atau tidak sensitif terhadap perubahan harga per unit barang yang bersangkutan) apabila prosentase perubahan jumlah yang diminta lebih kecil dari pada perubahan harga barang yang terjadi. Karena elastisitas permintaan selalu berhubungan dengan fungsi permintaan yang memilki slope negatif, nilai elastisitas (kecuali elastisitas silang) selalu diletakkan dalam harga mutlak.

Bagi seorang pengusaha (produsen), elastisitas sangat bermanfaat untuk pertimbangan pengambilan keputusan. Misalnya, pengusaha tersebut mengetahui bahwa elastisitas permintaan akan suatu barang dagangannya bersifat elastis. Artinya, pengusaha tersebut berhadapan dengan pembeli yang "sensitif " terhadap perubahan harga. Apabila ia menaikkan harga sebesar $1 \%$, konsumen akan mengurangi jumlah pembeliannya lebih dari $1 \%$. Sebaliknya apabila ia menurunkan harga (misal $1 \%$ ), jumlah barang yang diminta akan naik lebih dari $1 \%$. Dengan demikian ia dapat meningkatkan pendapatan total.

\subsection{Jenis-Jenis Elastisitas}

Terdapat 4 (empat) jenis elastisitas yang ada, yaitu (1). Elastisitas Permintaan/harga; (2). Elastisitas Pendapatan; (3). Elastisitas Silang; dan (4). Elastisitas Penawaran. Untuk memahami ke empat elastisitas tersebut maka akan dijelaskan satu per satu sebagai berikut:

\section{a. Elastisitas Permintaan (Elastisitas Harga)}

Kurva permintaan yang memiliki niliai koefisien arah negatif menunjukkan bahwa jumlah yang diminta berhubungan terbalik dengan tingkat harga perunit barang tersebut. Seberapa besar jumlah permintaan akan berubah jika harga mengalami perubahan?. koefisien elastisitas harga (price elasticity of demand) mengukur prosentase perubahan jumlah yang diminta akibat prosentase perubahan harga 
barang tersebut. Dengan kata lain elastisitas harga suatu barang merupakan proporsi perubahan barang yang diminta dibagi proporsi perubahan harga barang tersebut. Secara matematis elastisitas permintaan dapat dirumuskan sebagai berikut:

$$
\mathrm{Ep}=\frac{\% \mathrm{Q}}{\% \mathrm{P}}=\frac{\Delta \mathrm{Q} / \mathrm{Q}}{\Delta \mathrm{P} / \mathrm{P}}=\frac{\Delta \mathrm{Q}}{\Delta \mathrm{P}} \cdot \frac{\mathrm{P}}{\mathrm{Q}}
$$

Sehubungan dengan elastisitas sifat suatu barang dalam kaitanya dengan perubahan suatu barang dapat dibedakan menjadi tiga, yaitu;

a. Elastisitas $\left(E_{p}>1\right)$, apabila harga berubah $1 \%$, maka jumlah barang yang diminta berubah lebih dari $1 \%$.

b. Inelastis $\left(E_{p}<1\right)$, apabila harga berubah $1 \%$, maka jumlah barang yang diminta kurang dari $1 \%$

c. Uniter $\left(E_{p}=1\right)$, apabila harga berubah $1 \%$, maka jumlah barang yang diminta berubah $1 \%$.

Kondisi tersebut apabila digambarkan dalam suatu grafik maka akan nampak pada Gambar 5. 1. sebagai berikut:

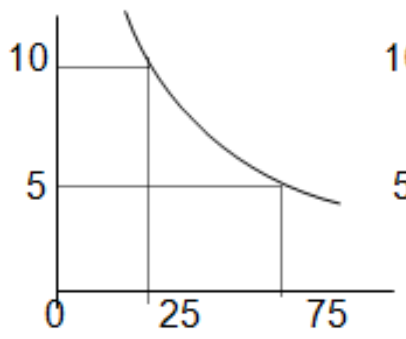

Elastis

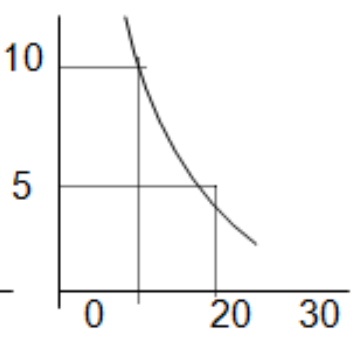

Inelastis

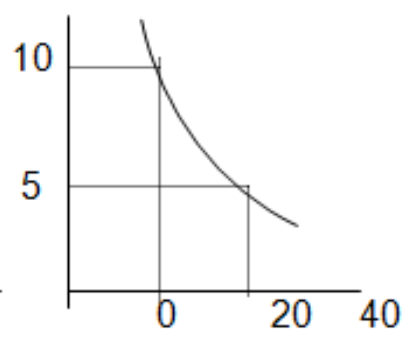

Uniter

Gambar 5. 1. Elastis, Inelastis dan Uniter

Di muka telah diuraikan bahwa slope berbeda dengan elastisitas. Kurva permintaan pada gambar di atas bukan merupakan garis lurus. Kurva tersebut tidak memiliki slope yang kosntan, namun kurva ini memiliki elastisitas yang kosntan. Untuk kurva permintaan yang linier maka elastisitas permintaan di sepanjang kurva tersebut tidak konstan.

Adapun faktor-faktor yang mempengaruhi besarnya koefisien elastisitas harga dari permintaan adalah: 
- Jumlah dan eratnya hubungan substitusi antar komoditi

Semakin banyak dan semakin baik barang substitusi untuk suatu komoditi, maka elastisitas harga dari permintaan untuk komoditi tersebut cenderung semakin besar.

- Jumlah penggunaan komoditi

Semakin besar jumlah penggunaan suatu komoditi, akan semakin besar elastisitas harganya

- Pengeluaran atas komoditi

Semakin besar persentase pendapatan yang dibelanjakan untuk suatu komoditi, maka elastisitas komoditi tersebut cenderung membesar.

- Masa Penyesuaian

Semakin lama periode penyesuaian jumlah barang yang akan dibeli, maka permintaannya semakin elastic

- Tingkat harga

Jika harga bergerak ke bagian kurva permintaan yang lebih tinggi maka permintaan akan cenderung lebih elastis daripada jika harga bergerak menuju ke bagian kurva permintaan yang lebih rendah.

\section{b. Elastisitas Pendapatan}

Koefisien elastisitas pendapatan (income Elasticity of demand) mengukur prosentase perubahan jumlah barang yang dibeli sebagai akibat prosentase perubahan pendapatan. Secara matematis pengertian di atas dapat ditulis dalam persamaan berikut ini:

$$
\mathrm{Ei}=\frac{\% \Delta \mathrm{Q}}{\% \Delta \mathrm{I}}=\frac{\Delta \mathrm{Q}}{\Delta \mathrm{I}} \cdot \frac{\mathrm{I}}{\mathrm{Q}}
$$

Jenis barang yang dibeli yaitu: barang normal, barang inverior, atau barang mewah, akan menentukan nilai koefisien elastisitas. Apabila nilai Ei mempunyai nilai negatif, jenis barang adalah inferior; jika Ei mempunyai nilai positif, barang yang dibeli adalah barang normal. Barang normal biasanya mewah jika $\mathrm{Ei}>1$. Tingkat pendapatan konsumen sangat mempengaruhi sikap konsumen terhadap suatu barang. Konsumen yang mempunyai pendapatan tertentu bisa menganggap suatu barang adalah barang normal, tetapi dengan pendapatan tertentu pula konsumen bisa menganggap barang itu adalah barang mewah. 


\section{c. Elastisitas Silang}

Koefisien elastisitas silang (cross Elasticity of Demand) mengukur prosentase perubahan jumlah suatu barang (misalnya $X$ ) yang dibeli akibat prosentase perubahan barang yang lain (misal $Y$ ). pernyataan tersebut secara matematis dapat dinyatakan sebagi berikut:

$$
\text { Exy }=\frac{\Delta Q x}{\Delta P y} \cdot \frac{P y}{Q x}
$$

Besarnya koefisen elastisitas akan menentukan sifat hubungan antara kedua barang. Hubungan kedua barang dapat bersifat subtitusi (saling mengganti) atau komplementer (saling melengkapi) nilai Exy $>0$ berarti antara barang $X$ dan $Y$ mempunyai hubungan yang dapat mengganti (subtitusi). Jika $X$ dan $Y$ mempunyai hubungan yang saling melengkapi (komplementer) nilai Exy $<0$. Selain itu ada dua barang yang tidak memiliki hubungan (netral), oleh karena itu apabila barang dikatakan netral jika nilai Exy $=0$.

\section{d. Elastisitas Penawaran.}

Koefisien elastisitas penawaran (price elasticity of supply) mengukur prosentase perubahan jumlah barang yang ditawarkan akibat harga barang itu sendiri. Secara matematis pernyataan tersebut di atas dapat ditulis dalam persamaan sebagai berikut:

$$
\mathrm{Es}=\frac{\% \mathrm{Q}}{\% \mathrm{P}}=\frac{\Delta \mathrm{Q}}{\Delta \mathrm{P}} \cdot \frac{\mathrm{P}}{\mathrm{Q}}
$$

Pada penawaran nilai koefisien adalah positif, berdasarkan sifat elastisitas penawaran dapat dibedakan menjadi 3, yaitu;

1. Es $>1$ disebut elastis, misal harga naik $10 \%$ maka jumlah barang yang ditawarkan akan naik lebih dari 10\%

2. Es $<1$ disebut inelastis, misal harga naik $10 \%$, maka jumlah barang yang ditawarkan akan naik kurang dari $10 \%$.

3. $\mathrm{Es}=1$ disebut Uniter, misal harga naik $10 \%$, maka jumlah barang yang ditawarkan akan naik sebesar $10 \%$.

Faktor-faktor yang mempengaruhi besarnya koefisien elastisitas penawaran adalah sebagai berikut:

a. Keleluasaan untuk meningkatkan produksi. Jika input mudah didapatkan, output akan naik lebih besar apabila harga output naik. Jika kapasitas produksi terbatas, prosentase kenaikan harga output 
akan mengakibatkan prosentase kenaikan output yang ditawarkan relatif lebih kecil.

b. Jangka waktu untuk merespon. Perubahan harga cenderung mempunyai dampak yang besar pada kuntitas yang ditawarkan jika jangka waktu produsen untuk merespon perubahan yang lama.

\section{4. Latihan Soal}

1. Apa yang dimaksud dengan elastisitas?

2.Mengapa elastisitas tidak mengandung nilai (uniter)?

3. Apakah manfaat elastisitas bagi produsen atau pengusaha?

4. Sebut dan jelaskan empat jenis elastisitas!

5. Sebutkan faktor-faktor yang menentukan besarnya koefisien elastisitas harga dari permintaan!

6. a. Apakah elastisitas harga dari permintaan untuk rokok Marlboro lebih besar daripada elastisitas harga rokok lainnya pada umumnya? Mengapa?

b. Aturan umum apakah yang dapat kita simpulkan dari kasus ini?

7. a. Mengapa bila dua komoditi merupakan substitusi satu sama lain, elastisitas silang dari permintaan antara keduanya positif, sedangkan bila keduanya bersifat komplemen, elastisitas silangnya negatif?

b. Bagaimana kita dapat mendefinisikan suatu industry dengan menggunakan elastisitas silang? Kesulitan apakah yang dihadapi?

8. Dari tabel dibawah ini yang menjelaskan skedul permintaan pasar

a. Carilah elastisitas harga dari permintaan untuk pergerakan dari titik $B$ ke titik $D$, dari titik $D$ ke titik $B$ dan pada titik tengah antara $B$ dan D

b. Lakukan hal yang sama untuk titik-titik D dan $G$

\begin{tabular}{|c|c|c|c|c|c|c|c|}
\hline Titik & A & B & C & D & E & F & G \\
\hline P & 6 & 5 & 4 & 3 & 2 & 1 & 0 \\
\hline Q & 0 & 20. & 40. & 60. & 80. & 100. & 120. \\
& & 000 & 000 & 000 & 000 & 000 & 000 \\
\hline
\end{tabular}

\section{Istilah - istilah penting ;}

Elastisitas, Elastis, Inelastis, Uniter.

Elastisitas harga, Elastisitas pendapatan, Elastisitas penawaran dan elastistas Silang.

Barang normal, inferior, mewah, subtitusi, komplementer. 


\section{BAB 6 \\ TEORI PRODUKSI}

\section{TUJUAN INSTRUKSIONAL KHUSUS}

1. Mahasiswa dapat mendefinisikan konsep teori produksi

2. Mahasiswa mengetahui bentuk fungsi-fungsi produksi

3. Mahasiswa dapat menjelaskan dan mengidentifikasi tahapantahapan produksi

4. Mahasiswa dapat menjelaskan dan membedakan proses produksi dalam jangka pendek dan dalam jangka panjang

\subsection{Pendahuluan}

Dalam ilmu ekonomi, setiap proses produksi memiliki elemen utama yaitu input, proses, dan output. Input merupakan sumber daya yang digunakan dalam proses produksi. proses merupakan cara yang digunakan untuk menghasilkan produk yang diinginkan. Ouput adalah produk yang ingin dihasilkan dalam suatu proses produksi. keterkaitan elemen-elemen tersebut nampak pada gambar berikut:

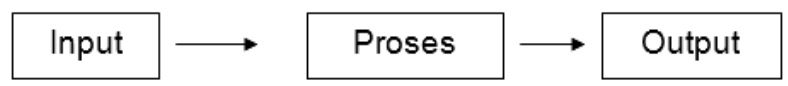

Gambar 6. 1. Skema Sistem Produksi

Sumber daya yang dimiliki perusahaan dalam satu aktivitas produksi bersifat terbatas (langka) oleh karena itu perusahaan harus mampu menentukan cara berproduksi yang tepat. Suatu proses produksi dapat dikatakan tepat jika proses produksi tersebut efisien. Artinya dengan sejumlah sumber daya (input) tertentu dapat menghasilakan produk (output) yang maksimum. Atau unutuk menghasilkan sejumlah produk (ouput) tertentu digunakan sumber daya (input) yang minimum.

Kegiatan produksi di dalam perekonomian menghasilkan berbagai macam barang dan jasa. Dalam proses produksi diperlukan berbagai input atau faktor produksi. dalam melakukan kegiatan produksi, produsen selalu berusaha menghasilkan output secara efisien, atau dengan biaya yang rendah. Produsen selalu berusaha menghsilkan ouput yang maksimum dengan input tertentu atau menghasilkan tingkat 
output tertentu dengan input yang minimum. Dengan mengambil keputusan barang atau jasa apa yang akan ditawarkan dan dijual, produsen atau perusahaan selalu bertindak secara rasional.

\subsection{Fungsi Produksi}

Beberapa faktor produksi atau input yang digunakan akan menghasilkan output. Jumlah output juga dipengaruhi oleh tehnologi yang digunakan. Hubungan antara input dan output yang dihasilkan dengan teknologi tertentu disebut dengan fungsi produksi. Fungsi produksi adalah suatu fungsi atau persamaan yang menunjukkan hubungan antara tingkat (dan kombinasi) penggunaan input dan tingkat output per satuan waktu. Secara umum fungsi produksi dinyatakan sebagai berikut:

$$
Q=f(X 1, X 2, X 3, \ldots \ldots \ldots \ldots . . . X n) \text {. }
$$

Dimana: $Q$ adalah tingkat output, dan $X 1, X 2, X 3, \ldots \ldots \ldots . . X n$ adalah berbagai jumlah input yang digunakan. Dengan menggunakan fungsi produksi tertentu kita dapat menunjukkan jumlah output maksimum yang dapat dihasilkan dengan sejumlah input tertentu atau menghasilkan tingkat output tertentu dengan jumlah input minimum, dan semua itu menggunkan teknologi tertentu.

Fungsi produksi menjelaskan hubungan input dengan output. Fungsi produksi tersebut menentukan kemungkinan output maksimum yang bisa diproduksi dengan sejumlah input tertentu. Sebaliknya fungsi produksi juga menunjukkan kuantitas input minimum yang diperlukan untuk memproduksi suatu tingkat output tertentu.

Fungsi produksi dipengaruhi oleh beberapa faktor yang salah satu diantaranya adalah teknologi yang tersedia bagi sebuah perusahaan. Oleh karena itu, hubungan input/output untuk setiap sistem produksi merupakan suatu fungsi dari hubungan tingkat teknologi yang akan diterapkan di pabrik tertentu, ketersedian peralatan, kuantitas dan kualitas tenaga kerja, bahan-bahan dan lain-lain yang digunakan perusahaaan tersebut. Setiap usaha pengembangan proses produksi seperti perbaikan teknologi seperti pemakaian komputer untuk melakukan proses pengendalian yang memungkinkan sebuah perusahaan manufacturing bisa memproduksi sejumlah output tertentu dengan bahan baku yang lebih sedikit, penggunaan energi dan tenaga kerja yang lebih sedikit, adanya suatu program pengembangan keterampilan yang bisa meningkatkan produktivitas tenaga kerja, akan mampu menghasilkan sebuah fungsi produksi yang baru. 
Fungsi produksi (hubungan antara input dan output) mempunyai ragam yang jumlahnya banyak sekali dan untuk masing-masing produk mempunyai fungsi produksi yang berbeda. Dalam perekonomian dimana teknologi dapat berubah dengan cepat, seperti telomonikasi, fungsi produksi menjadi cepat usang. Meskipun demikian para ekonom mengemukakan bahwa fungsi produksi sangat bermanfaat dalam menggambarkan kapabilitas produkstif sebuah perusahaan.

\subsection{Produk Total, Produk Rata-rata, dan Produk Marginal}

Fungsi produksi dapat digunakan untuk tiga konsep produksi yaitu produk total, produk rata-rata, dan produk marginal. Dalam proses produksi kita menjumpai input tetap (fixed input) dan input variabel (variabel input). Input tetap adalah input yang jumlahnya selalu tetap meskipun tingkat ouputnya berubah, input variabel adalah input yang akan selalu berubah seiring dengan jumlah output yang berubah. Jumlah output secara total disebut dengan produk total (total phisichal product=TPP). Produk total dibagi dengan jumlah input variabel tertentu menghasilkan produk rata-rata (average physichal product=APP). Penggunaan jumlah input variabel yang berubah akan menyebabkan jumlah total produksi berubah. Perubahan total produksi sebagai akibat perubahan penggunaan satu unit variabel disebut produk marginal (marginal physical product). Contoh penghitungan produk marginal dan produk rata-rata disajiikan dalam tabel berikut.

Tabel 6. 1. Tabel Produksi

\begin{tabular}{|c|c|c|c|c|}
\hline Input tetap & $\begin{array}{c}\text { Input } \\
\text { variabel }\end{array}$ & $\begin{array}{c}\text { Jumlah } \\
\text { output (TP) }\end{array}$ & $\begin{array}{c}\text { Marginal } \\
\text { Product } \\
\text { (MP) }\end{array}$ & $\begin{array}{c}\text { Avarage } \\
\text { product (AP) }\end{array}$ \\
\hline 4 & 0 & 0 & - & - \\
4 & 1 & 36 & 36 & 36 \\
4 & 2 & 81 & 45 & 40,5 \\
4 & 3 & 129 & 48 & 43 \\
4 & 4 & 174 & 45 & 43,5 \\
4 & 5 & 215 & 41 & 43 \\
4 & 6 & 236 & 21 & 39,33 \\
4 & 7 & 226 & -10 & 32,29 \\
4 & 8 & 199 & -27 & 26,13 \\
\hline
\end{tabular}

Sumber: Endang Sulistyowati dkk, 200: 83. 
Tabel 6. 1. kolom 3 menggambarkan produk total. Dari kolom tersebut dapat dilihat bagimana produk total berubah dengan adanya perubahan input variabel yang digunakan. Produk total bernilai nol untuk penggunaan input variabel yang digunakan, mencapai maksimum, dan kemudian menurun. Input tetap (kolom 1) jumlahnya tetap pada tingkat output berapapun. Produk marginal (kolom 4) dari sebuah input adalah jumlah produk yang dapat dihasilkan dengan adanya penambahan satu unit input variabel sementara input lain tidak mengalami perubahan (tetap).

Konsep terakhir adalah adalah produk rata-rata, yang mengukur output total dibagi input total. Kolom 5 dari tabel 6. 1. menunjukkan produk rata-rata. Dalam contoh ini produk rata-rata akan mengalami penurunan sejalan naiknya jumlah dengan naiknya jumlah tenaga kerja yang digunakan. Dari tabel 6. 1. dapat dibuat menjadi sebuah gambar kurve sebagaimana ditunjukkan pada gambar 6. 2.berikut;

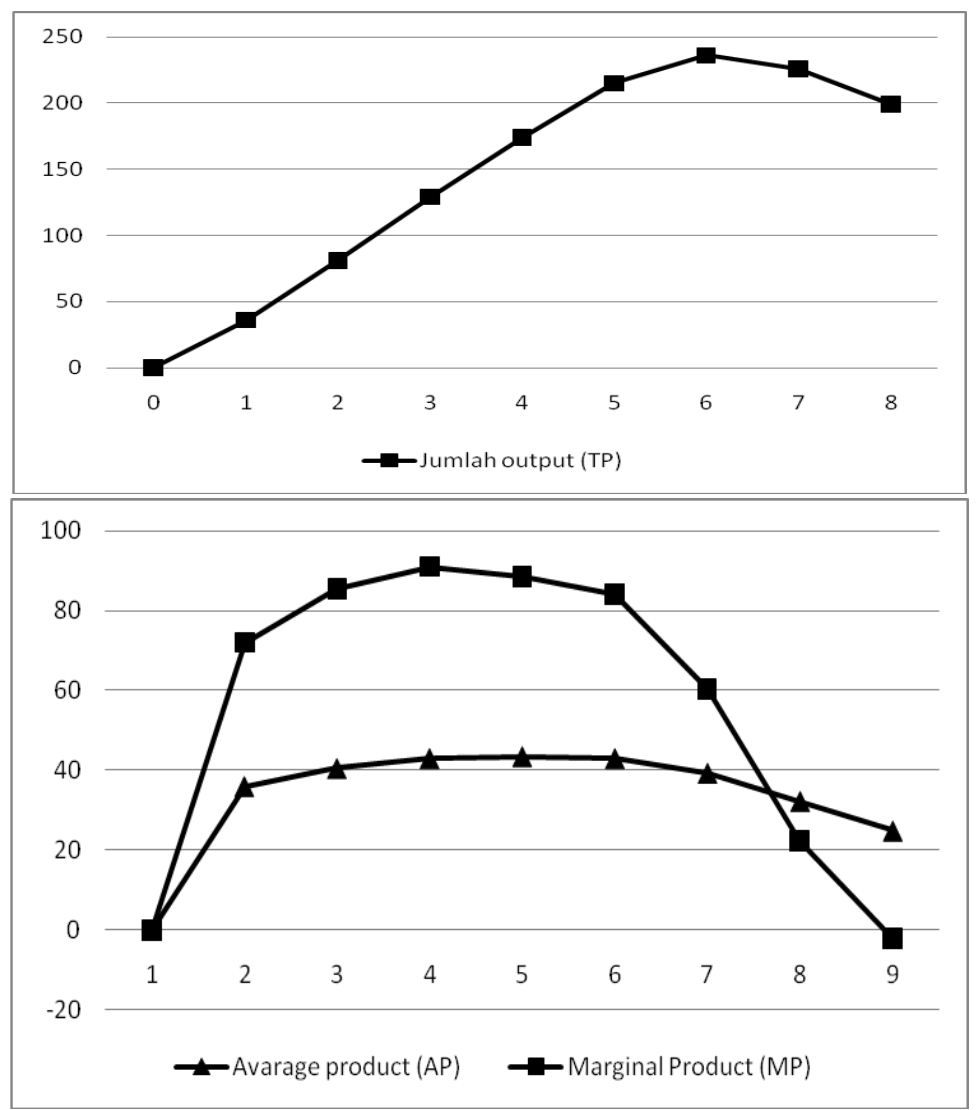

Gambar 6.2.Kurve TP, MP dan AP. 
Gambar 6.2.menunjukkan kurva produk total mula-mula mengalami kenaikan sejalan dengan pertambahan input variabel yang digunakan, kemudian mencapai maksimum dan seterusnya menurun, sementara input lain tetap. Sedangkan kurva Marginal Product semula mengalami kenaikan yang semakin meningkat pada saat total product meningkat dengan tingkat kenaikan yang semakin besar. Hal ini terjadi sejak input sama dengan 0 sampai dengan 3 unit.

Selanjutnya total product masih terus bertambah sampai dengan input sebesar 6 unit dimana output mencapai titik maksimum sebesar 236 unit. Sedangkan untuk marginal product mengalami penurunan mulai dari input ke 3 sampai dengan ke 6 . Sekalipun menurun tetapi marginal product masih mempunyai nilai positif. Tetapi pada saat total product menurun maka nilai marginal product sudah negatif. Gambar 6.3. menjelaskan kaitan TP, AP dan MP

Produk Total (Q)
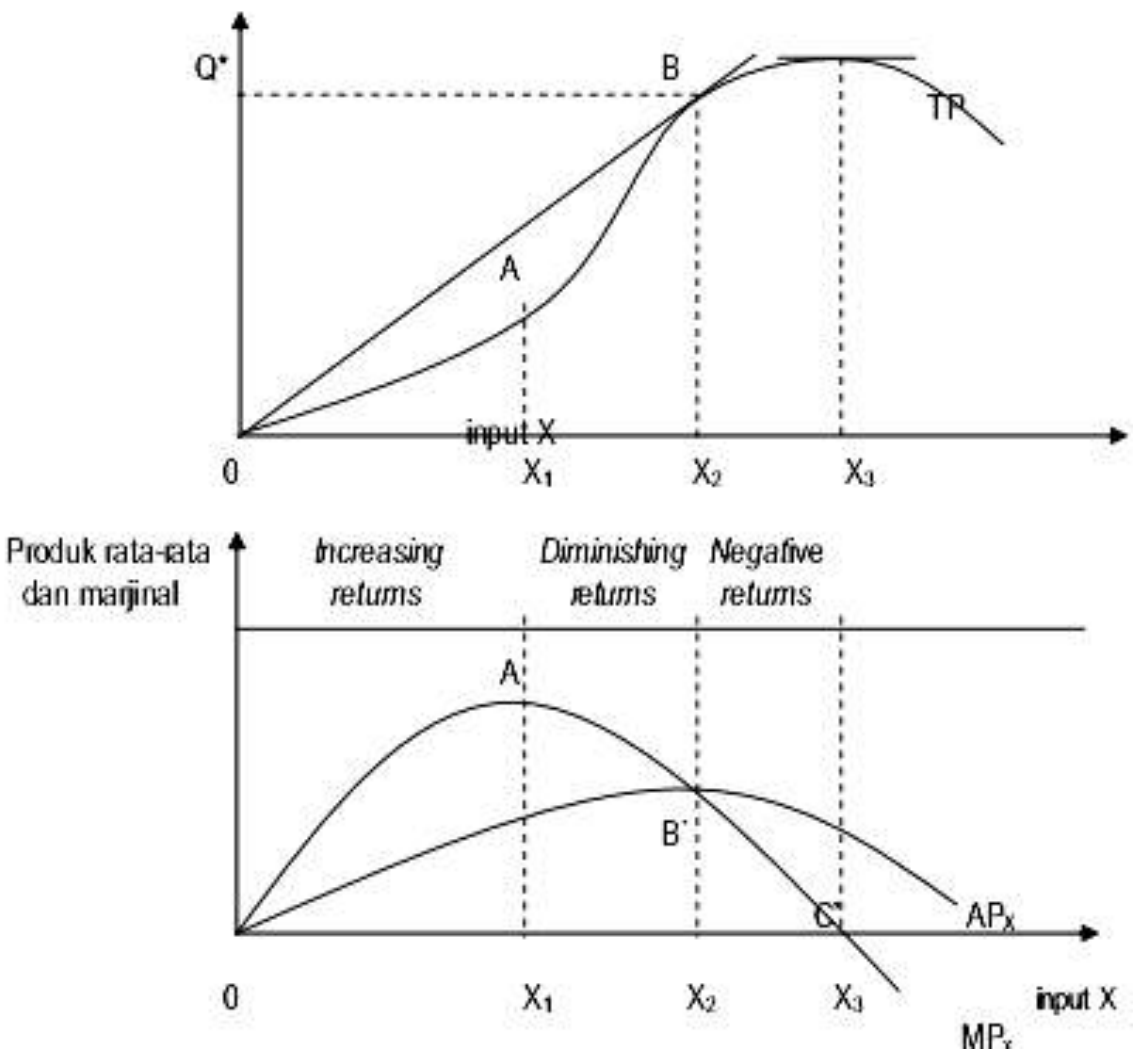

Gambar 6.3 Hubungan Kurva Produk Total dengan Average Product dan Marginal Product 
Dari Gambar 6. 3. dapat dilihat adanya pola hubungan antara ketiga kurva tersebut. Pada fase awal, kurva total product meningkat dengan tingkat pertambahan yang semakin menaik. Hal ini ditandai dengan naiknya kurva marginal product sampai dengan titik A yang merupakan titik balik (inflection point). Setelah itu, kurva total product tetap naik tapi dengan tingkat pertambahan produk yang semakin menurun. Kondisi ini terus terjadi sampai pada titik B. Kondisi kurva marginal product di antara titik A dan B adalah menurun tapi masih positif. Sedangkan kurva average product terus naik sejak titik nol (asal) sampai dengan titik B. Pada titik B, slope kurva produk total sama dengan nilai rata-rata produk. Oleh karena di titik $\mathrm{B}$, terjadi pertemuan antara kurva marginal product dan rata-rata product. Kurva total product akan mencapai puncak pada titik C. Pada titik ini, kurva marginal product mempunyai nilai $\mathrm{O}$. Jadi pada saat kurva total product maksimal maka nilai marginal product adalah nol.

\subsection{Kurva Isokuan}

Sama dengan teori permintaan yang mempunyai konsep kurva indiferen untuk menunjukkan kurva kepuasan yang sama dalam mengkonsumsi suatu barang. Teori produksi juga mempunyai konsep kurva isokuan. Kurva ini identik dengan kurva indiferen yang diterapkan di tingkat produsen. Kurva isokuan juga disebut kurva produk yang sama. Kurva tersebut menunjukkan berbagai kombinasi dari penggunaan beberapa input yang berbeda-beda untuk menghasilkan produk yang sama jumlahnya.

Walaupun kita bisa mempelajari sifat-sifat fungsi produksi secara grafis dengan menggunakan permukaan produksi tiga dimensi seperti yang digambarkan dalam gambar 6. 4. Tetapi penyajian dan penjelasan secara dua dimensi dengan menggunakan isokuan biasanya, lebih mudah untuk digunakan. Istilah isokuan, berasal dari kata iso yang berarti sama dan quant yang berarti kuantitas, menggambarkan sebuah kurva yang menunjukkan semua kombinasi input yang berbada yang dikombinasikan secara efisien untuk menghasilkan sejumlah output tertentu. 


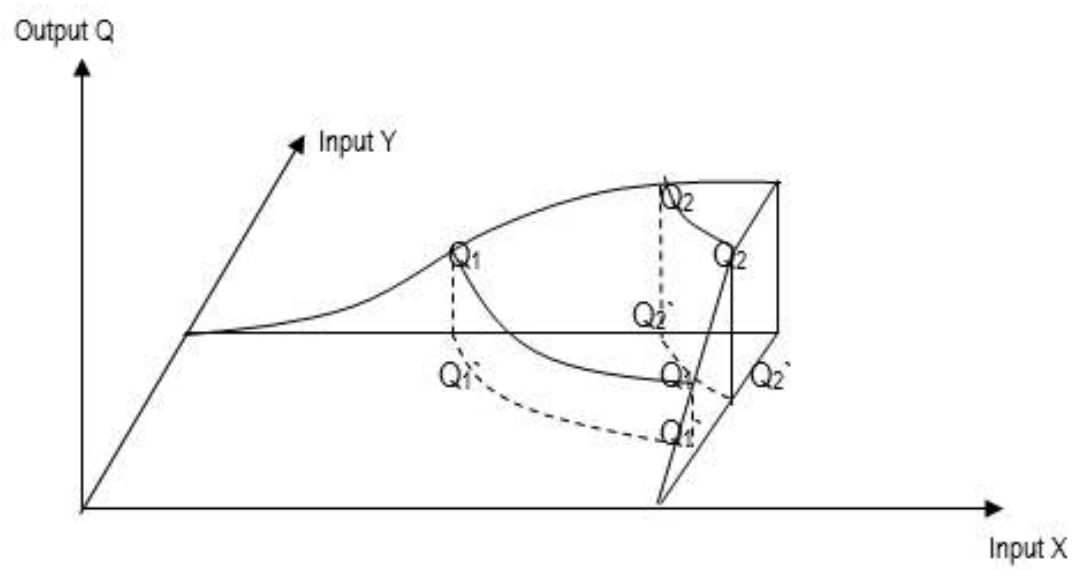

Gambar 6. 4. Penentuan Isokuan

Kurva isokuan tersebut bisa dipindahkan ke permukaan input seperti ditunjukkan oleh kurva-kurva Q2' dan Q2" dalam gambar 6. 4 dan kemudian dipindahkan ke gambar dua dimensi yang ditunjukkan dalam gambar 6. 5. Kurva-kurva yang terakhir ini menunjukkan bentuk standar dari sebuah isokuan.

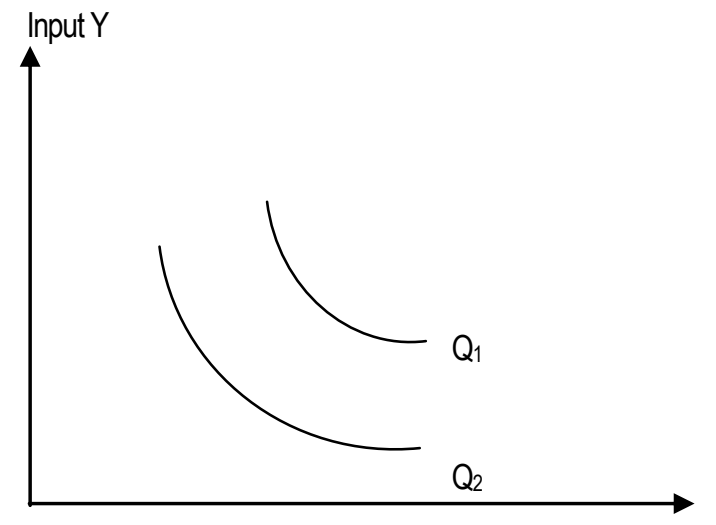

Input X

Gambar 6. 5. Isokuan Produksi

Karakteristik umum kurva isokuan pada dasarnya sama dengan ciri-ciri kurva indiferen. Kurva-kurva tersebut tidak saling berpotongan, jumlah isokuan dalam peta produksi tak terhitung banyaknya, mempunyai sifat konveksitas atau cembung terhadap titik asal sehingga kurva-kurva itu menurun dari kiri atas ke kanan bawah. Kurva isokuan diilustrasikan pada Gambar 6. 6. 


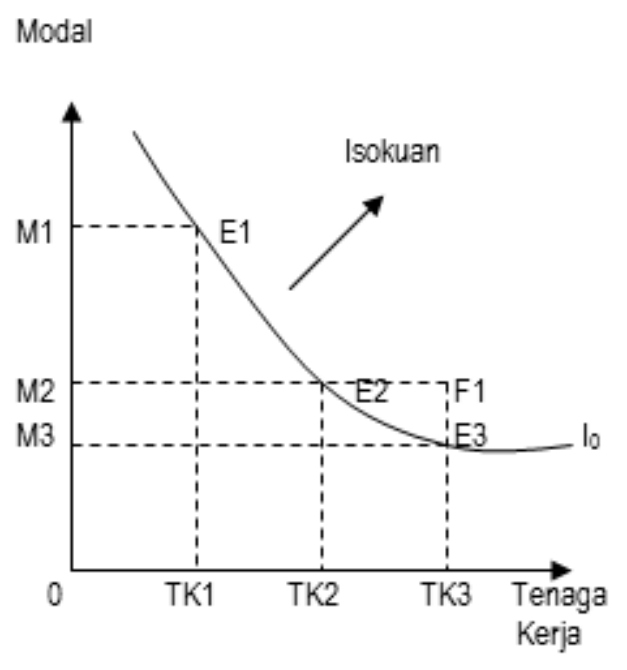

Gambar 6. 6. Kurva Isokuan

Misalnya untuk memproduksi $X$ unit output dibutuhkan dua jenis input yaitu modal (M) dan tenaga kerja (TK). Kedua jenis input ini dapat digunakan dengan berbagai kombinasi yang berbeda-beda untuk menghasilkan $X$ unit output, asalkan berada pada garis kurva isokuan $\mathrm{I}_{\mathrm{O}}$. Output yang mungkin dihasilkan adalah E1, E2 dan E3, yang semuanya berada pada kurva isokuan $\mathrm{I}_{0}$. E1 dihasilkan dari penggunaan modal sebanyak M1 dan tenaga kerja sebanyak TK1, Kombinasi antara M2 dan TK2 akan menghasilkan E2 dan E3 merupakan produk yang dihasilkan dari kombinasi modal sebanyak (M3) dan tenaga kerja sebanyak (TK3). Produsen juga dapat menghasilkan $\mathrm{F} 1$ dari penggunaan modal sebanyak M2 dan tenaga kerja sebanyak TK3 namun produk yang dihasilkan tidak berada pada kurva isokuan $I_{0}$ atau dengan kata lain jumlah output yang dihasilkan berbeda dengan E1, E2 dan E3.

Konsep selanjutnya yang perlu dibahas setelah kurva isokuan adalah isocost (Gambar 6. 7). Dua konsep tersebut dipergunakan untuk menjelaskan keseimbangan produsen. Isocost line (garis biaya sama) menunjukkan kombinasi yang berbeda-beda dari input yang dapat dibeli oleh perusahaan pada kondisi dimana harga faktor-faktor produksi inti konstan dan tersedia pengeluaran biaya tertentu. Jadi permasalahan perusahaan dapat dirumuskan secara sederhana yaitu produsen pada konisi isokos tertentu ingin mencapai isokuan yang tertinggi. 


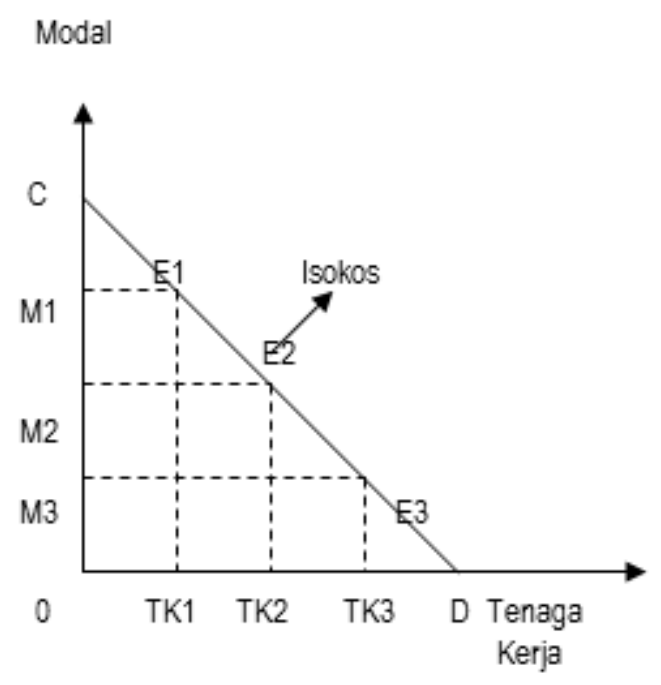

Gambar 6. 7. Kurva Isokos

Isokos adalah garis yang menghubungkan titik-titik kombinasi penggunaan input modal dan tenaga kerja yang mengeluarkan ongkos yang sama. Isokos mempunyai ciri sebagai berikut: apabila isokos semakin mendekati nol (0), semakin kecil ongkos yang digunakan untuk operasional produk, begitu juga sebaliknya apabila isokos menjauhi titik asal maka biaya yang dikeluarkan semakin besar dan akan memperbesar pula pemakaian modal dan tenaga kerja.

Sebagaimana diketahui isokuan adalah kurva yang menghubungkan titik-titik kombinasi penggunaan modal dan tenaga kerja yang menghasilkan output yang sama. Gambar 6. 8 menunjukkan bahwa semakin besar produk yang dihasilkan maka semakin banyak input $Y$ dan $X$ yang dibutuhkan. Pada kurva isokuan $Q_{1}$ menghasilkan 91 unit output sedankan isokuan $Q_{2}$ menghasilkan 122 unit. Konsekuensi dari besarnya output yang dihasilkan, $Q_{2}$ membutuhkan input yang lebih besar yaitu 11 unit $Y$ dan 8 unit $X$. Sedangkan $Q_{1}$ pada satu titik membutuhkan 9 unit input $Y$ dan 3 unit input $X$. 


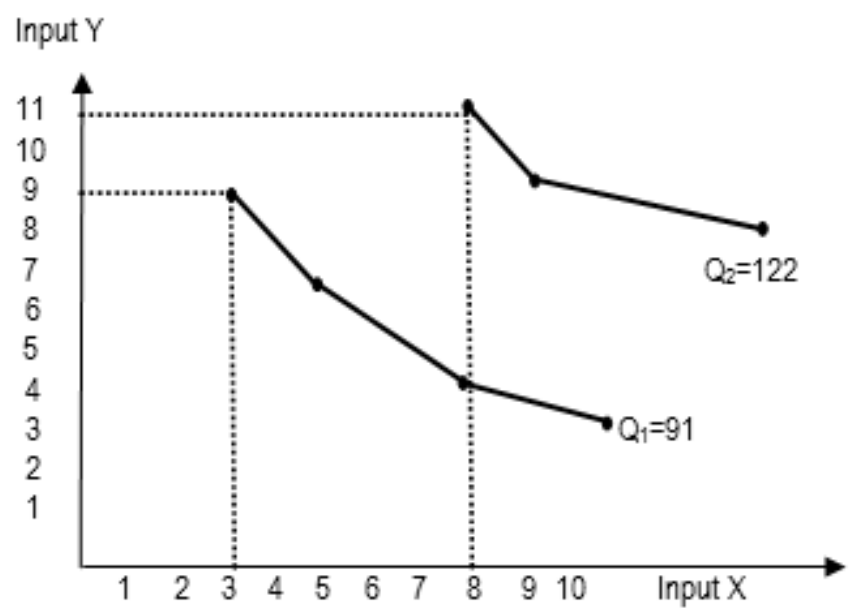

Gambar 6. 8. Peta Isokuan

Lebih lanjut dikemukakan bahwa pengalokasian sumberdaya dikatakan efektif dan efisien pada saat isokuan bersinggungan dengan isokos (Gambar 6. 9). Pada titik E, produsen bisa memproduksi barang dengan anggaran sebesar $\mathrm{IC}_{0}$ dengan output maksimal yang dihasilkan adalah pada kurva isokuan $\mathrm{IQ}_{0}$. Dengan isokos sebesar $\mathrm{IC}_{0}$ produsen tidak bisa memproduksi pada titik $F$ karena kurva isokuan $I Q_{1}$ berada jauh diatas $\mathrm{IC}_{0}$.

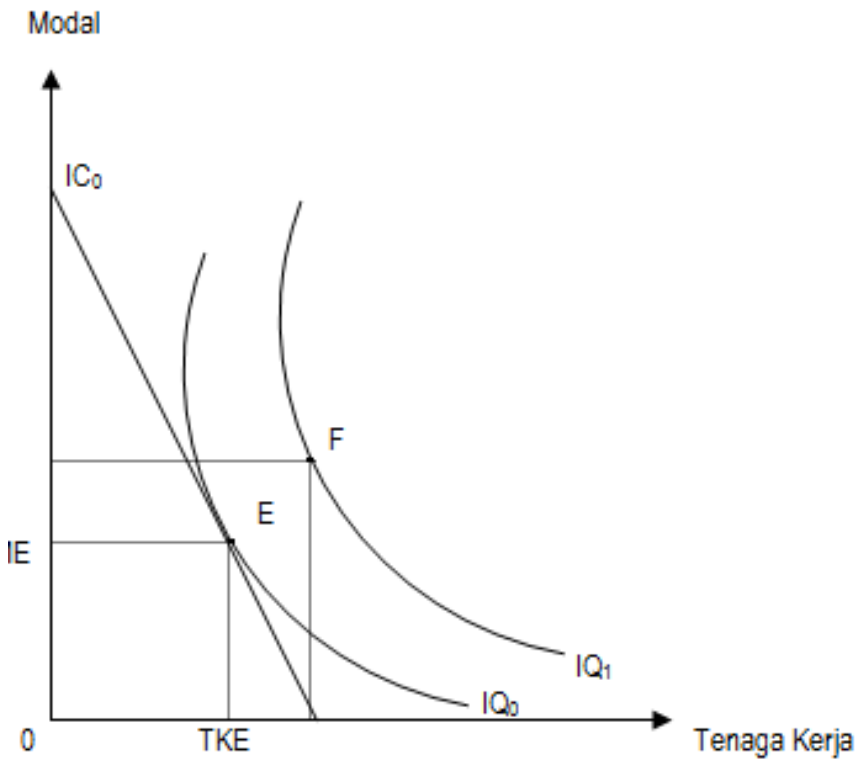

Gambar 6. 9.Kurva Keseimbangan isokos dan isokuan 


\subsection{Hukum Pertambahan yang Semakin Berkurang}

Dengan menggunakan fungsi produksi, kita dapat memahami satu dari hukum yang paling dikenal dalam ilmu ekonomi, yaitu hukum penambahan hasil yang semakin berkurang (the law of diminishing returns). Hukum penambahan hasil yang semakin berkurang menyatakan bahwa kita akan memperoleh tambahan output yang mulamula menaik, mencapai maksimum, kemudian menurun hingga sama dengan nol dan seterusnya negatif apabila satu input ditambah terus penggunaannya sementara input lain adalah tetap. Dengan kata lain produk marginal dari setiap input variabel mula-mula menaik, mencapai maksimum, kemudian menurun hingga sama dengan nol dan seterusnya akan negatif, sementara input yang lain jumlanya tetap.

\subsection{Tahap-Tahap Produksi}

Dalam produksi jangka pendek, tahap produksi dibagi menjadi tiga tahap, yaitu; tahap produksi I, tahap produksi II, dan tahap produksi III. Tahap produksi I dimulai dari produk total yang mulai menaik, produk marginal dan produk rata-rata juga naik. Pada tahap produksi I produk rata-rata per unit variabel naik. Batas tahap I adalah dimana produk marginal sama dengan produk rata-rata dan produk rata-rata mencapai titik maksimum. Gambar 6. 10 menunjukkan kurva tahapan produksi.

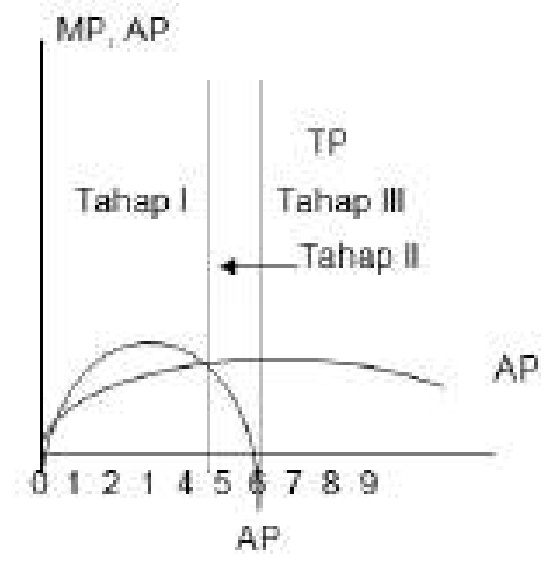

Gambar 6. 10.Kurva Tahapan Produksi

Tahap produksi II dimulai dari titik produk marginal sama dengan nol. Pada tahap ini produk total terus naik dengan laju yang berkurang, nilai produk marginal mengalami penurunan, dan nilai produk rata-rata 
mulai menurun. Batas kanan tahap produksi II adalah pada produk total mencapai maksimum atau produk marginal sama dengan nol.

Tahap III dimulai dari titik dimana produk marginal sama dengan nol. Pada tahap ini, produk total mengalami penurunan dan produk marginal bernilai negatif.

\subsection{Return to Scale (Skala Keuntungan)}

Dari fungsi produksi barang tertentu dapat dijelaskan jenis return to scale-nya. Ada tiga macam return to scale, yaitu ;

a. Constant returns to scale (skala hasil tetap), menunjukkan perubahan jumlah output yang proporsional dengan perubahan jumlah semua input yang digunakan. Contoh, jika tenaga kerja, tanah, modal dan input lain di dua kalikan maka ouput juga naik sebesar dua kalinya.

b. Decreasing returns to scale (skala hasil turun), terjadi apabila perubahan jumlah output yang dihasilkan tidak proporsional (lebih kecil) dibanding perubahan jumlah semua input yang digunakan. Contoh, seorang petani yang menggunakan semua inputnya sebesar dua kali dari semula menghasilkan output yang kurang dari dua kali dari output semula.

c. Incresing returns to scale (skala hasil naik), terjadi apabila perubahan semua input akan menghasilkan perubahan output yang lebih besar proporsinya dibandingkan perubahan input. Contoh, seorang petani yang menggunakan semua inputnya sebesar dua kali dari semula menghasilkan output yang lebih dari dua kali dari output semula.

\section{8. Analisis Jangka Pendek dan Jangka Panjang}

Di muka telah dijelaskan pengertian input tetap dan input variabel. Dalam analisis jangka pendek semua input adalah tetap. Tetapi dalam jangka panjang semua input adalah variabel. Jangka pendek dan jangka panjang ini sangat bergantunmg kemampuan produsen dalam mengubah input tetap menjadi input varabel. Mengubah input tetap menjadi input variabel ini tidak selalu terkait dengan lamanya waktu. Untuk perusahaan bersekala besar untuk mengubah input tetap menjadi input variabel tidak perlu membutuhkan waktu yang lama, sehingga analisisnya adalah analisis jangka panjang. Sebaliknya perusahaan kecil tidak bisa mengubah input tetapnya menjadi input variabel, sehingga analisisnya adalah analisis jangka pendek. 
Untuk lebih memahami konsep ini, diberikan contoh pabrik produksi cor baja "Kuat Tenan" merespon adanya perubahan permintaan. "Kuat Tenan" adalah pabrik baja yang mengoperasikan mesin pembakaran $70 \%$ dari kapasistasnya, apabila ada permintaan yang terjadi tentunya diakibatkan karena adanya jatuhnya pesaing. Untuk memenuhi permintaan yang baru, perusahaan dapat meningkatkan produksi dengan menambah jumlah jam kerja karyawan, dengan menambah tenaga kerja, dan dengan mengoprasikan pabriknya lebih intensif. Faktor-faktor yang dapat diubah atau dinaikkan penggunaannya dalam jangka pendek disebut input variabel. Dengan kata lain, input variabel adalah input yang jumlahnya tergantung pada jumlah output. Jadi, jumlah input variabel dapat diubah-ubah penggunaannya sesuai dengan tingkat output yang dikehendaki. Sehingga jangka pendek adalah dimana suatu pereode dimana produksi dapat diubah dengan mengubah input variabel.

Misalkan kenaikan permintaan baja berlangsung terus sampai beberapa tahun atau bahkan puluhan tahun. Pabrik baja Kuat Tenan akan menaikkan kapasistas produktifnya, dengan menambah semua input tetap yang jangka pendek tidak dapat diubah. Pereode dimana semua input dapat dirubah / disesuaikan penggunaannya disebut dengan jangka panjang. Di dalam contoh ini, Perusahaan baja Kuat Tenan akan menambah alat produksi yang baru dan lebih efisien, dengan menggunakan sistem yang sudah terkoputerisasi, atau dengan membangun pabrik baru. Jika semua input dapat disesuiakan, jumlah baja yang dihasilkan akan lebih banyak dan efisiensi dapat ditingkatkan.

\subsection{Latihan Soal}

1. Jelaskan konsep-konsep berikut: Total Product (TP), Average Product (AP) dan Marginal Product (MP)!

2. Jelaskan dengan grafik hubungan antara TP, MP dan AP!

3. Apakah yang dimaksud dengan kurva isokuan? Jelaskan dengan gambar

4. Berikan penjelasan singkat tentang isokos!

5. Jelaskan kondisi keseimbangan yang dapat dicapai oleh produsen! Kaitkan dengan isokuan dan isokos!

6. Dari tabel dibawah ini, selesaikan pertanyaan di bawah ini:

a. Carilah average product (AP) dan Marginal Product (MP) dari tenaga kerja!

b. Gambarkan kurva TP! 
c. Gambarkan kurva AP dan MP dari tenaga kerja dalam satu grafik!

\begin{tabular}{|c|c|c|c|c|c|c|c|c|c|c|}
\hline Tanah & 1 & 1 & 1 & 1 & 1 & 1 & 1 & 1 & 1 & 1 \\
\hline $\begin{array}{c}\mathrm{T} . \\
\text { Kerja }\end{array}$ & 0 & 1 & 2 & 3 & 4 & 5 & 6 & 7 & 8 & 9 \\
\hline $\mathrm{TP}$ & 0 & 2 & 3 & 6 & 12 & 14 & 15 & 15 & 14 & 13 \\
\hline $\mathrm{MP}_{\mathrm{TK}}$ & & & & & & & & & & \\
\hline $\mathrm{AP}_{\mathrm{TK}}$ & & & & & & & & & & \\
\hline
\end{tabular}

7. Sebutkan tiga jenis return to scale yang sering dihadapi dari fungsi produksi suatu barang!

\section{Istilah-istilah penting ;}

Produk total

Produk marginal

Produk rata-rata

Fungsi produksi

The law of diminishing returns

Input tetap

Input variabel

Constant returns to scale

Increasing returns to scale

Decreasing returns to scale

Analisis jangka panjang

Analisis jangka pendek 


\section{BAB 7 \\ TEORI BIAYA}

\section{TUJUAN INSTRUKSIONAL KHUSUS}

1. Mahasiswa dapat menjelaskan konsep teori biaya

2. Mahasiswa dapat menjelaskan definisi dari biaya total, biaya tetap dan biaya variabel

3. Mahasiswa mampu menghitung biaya produksi dan mengintepretasikannya

4. Mahasiswa dapat menentukan skala ekonomis produksi

\subsection{Konsep Dasar}

Teori biaya pada dararnya merupakan kumpulan dari penalaran, gagasan serta penjelasan lain yang dapat digunakan sebagai dasar untuk menjelaskan perilaku biaya. Dalam pengertian ekonomi, biaya (ongkos) didefinisikan sebagai semua beban yang harus ditanggung oleh produsen untuk menyediakan barang agar siap untuk digunakan konsumen (Iswandarno, 1990; Sudarman, 1996. Sementara Lipsey and Courant (1996) mendefinisikan biaya sebagai berikut: Cost is the value of inputs used to produce its output. Selanjutnya teori biaya biasanya disusun dengan asumsi bahwa biaya penyediaan barang bagi konsumen termasuk dalam biaya produksi.

Ide dasar mengenai konsep biaya produksi dalam analisis ekonomi adalah berpijak pada prinsip biaya produksi alternatif (the alternative cost of production) atau prinsip biaya produksi kesempatan (the opportunity cost of production)). Prinsip biaya produksi tersebut menjelaskan bahwa jika kondisi perekonomian dalam kondisi kesempatan kerja penuh (tidak ada tenaga kerja yang menganggur) input dan ouput telah dialokasikan dengan efisien diantara barangbarang dan atau jasa, kenaikan jumlah output (produksi) tertentu harus diikuti dengan penurunan jumlah output alternatif lainnya. Pandangan Lipsey and Courant (1996) mengenai opportunity cost adalah: "The opportunity cost of using something in a partichular venture is the benefit for some by not using it in its best alternative use". Disisi lain Keat and Young (1996) berpendapat bahwa: Opportunity cost is the ammount or 
subjective value that is forgone in choosing one activity over the next best alternative.

Selanjutnya ilmu ekonomi tidak mensyaratkan apakah biaya yang dimaksud harus merupakan pengeluaran bagi produsen (biaya eksplisit) atau tidak (biaya implisit). Pengeluaran yang dihadapi produsen biasanya merupakan biaya produksi eksplisit yakni biaya produksi yang harus dikeluarkan untuk input-input yang harus dibeli atau disewa dari pihak luar (Iswardono; 1996). Misalnya pembayaran untuk pembelian bahan mentah atau setengah jadi, upah tenaga kerja, pengeluaran untuk penyusutan.

Sedangkan biaya implisit adalah biaya produksi yang bersal dari penggunaan input-input yang dimiliki sendiri oleh produsen tersebut. Maurice (1999) menganggap bahwa: Implicit cost is the opportunity cost os using recources that are ownet by owners of the firms. Salah satu contoh biaya implisit adalah gaji yang dibayarkan kepada pemilik perusahaan yang juga bertindak sebagai pengelola perusahaan. Biasanya perusahaan, khususnya perusahaan kecil, kurang memperhitungkan adanya biaya produksi tersebut. Pengertian biaya menurut teori biaya harus mencakup pula besarnya gaji implisit tersebut, karena pemilik perusahaan telah mengorbankan kesempatannya untuk mendapatkan gaji di tempat lain.

\subsection{Biaya Total, Biaya Tetap dan Biaya Variabel}

Dalam jangka pendek, biaya total (Total Cost $=\mathrm{TC}$ ) yang dihadai produsen dikeluarkan untuk memperoleh beberapa jenis input sehingga biaya total tersebut mencakup biaya tetap total (Total Fixet Cost $=$ TFC) dan biaya total variabel (Total Variabel Cost $=$ TVC). Sedangkan dalam jangka panjang semua biaya bersifat variabel sebagai akibat dari pemanfaatan keseluruhan input variabel. Biaya tetap yang timbul sebagai akibat pembelian input tetap didefinisikan sebagi biaya yang besarnya tidak tergantung pada besar kecilnya jumlah output yang dihasilkan. Bahkan jika prodiuksi dihentikan untuk sementara waktu, maka biaya ini tetap dibayarkan.

Di sisi lain, biaya variabel yang timbul sebagai akibat dari pembelian input varabel, didefinisikan sebagai biaya yang besarnya berubah-ubah tergantung pada perubahan jumlah produksi (ouput) yang dihasilkan. Makin besar jumlah produksi yang diinginkan maka makin besar pula biaya variabel yang dihadapi. Yang termasuk dalam biaya 
variabel adalah biaya bahan baku, biaya tenaga kerja langsung, biaya eksploitasi pemanfaatan input tetap seperti bahan bakar dan biaya perawatan lainnya. Kedua jenis biaya produksi dapat ditunjukkan dengan jelas oleh angka-angka pada Tabel 7. 1. berikut;

Tabel 7. 1. Hubungan antara Output dengan TFC, TVC dan TC

\begin{tabular}{|c|c|c|c|}
\hline Jumlah output (Q) & TFC $(\$)$ & TVC $(\$)$ & TC $(\$)$ \\
\hline 0 & 55 & 0 & 55 \\
1 & 55 & 30 & 85 \\
2 & 55 & 55 & 110 \\
3 & 55 & 75 & 130 \\
4 & 55 & 105 & 160 \\
5 & 55 & 155 & 210 \\
6 & 55 & 225 & 280 \\
\hline
\end{tabular}

Sumber: Samuelson, Paul A, 1995.

Sedangkan kurve biaya total, biaya variabel dan biaya tetap dapat dilustrasikan pada gambar 7. 1. berikut ini;

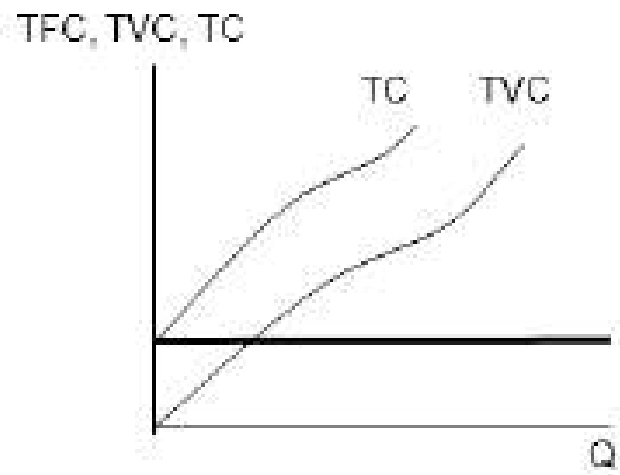

Gambar 7. 1. Kurva Biaya Total, Biaya Variabel dan Biaya Tetap

Kurva biaya total dan biaya variabel tidak mutlak memiliki bentuk non linier seperti di atas, tetapi bentuk kurva TC dan TVC bisa berbentuk Linier.

\subsection{Biaya Rata-Rata dan Biaya Marginal}

Dalam pembicaraan sehari-hari kadang kala tanpa disadari kita mengatakan bahwa biaya total yang besar diasosiasikan dengan mahal 
dan yang rendah dianggap murah. Hal ini tidak sepenuhnya benar karena ada ukuran lain yang dapat digunakan untuk maksud tersebut yakni biaya rata-rata (Average Cost $=\mathrm{AC}$ ). Seperti di atas biaya rata-rata diliputi biaya tetap rata-rata (Average Fixet Cost $=\mathrm{AFC}$ ) dan biaya ratarata variabel (Average Variabel Cost $=\mathrm{AVC}$ ). AFC merupakan besarnya biaya tetap total untuk setiap unit output yang dihasilkan dan diperoleh dengan membagi biaya tetap total dengan output yang dihasilkan, atau AFC = TFC/Q. Sedangkan AVC merupakan besarnya biaya variabel total untuk setiap unit output yang dihasilkan dan diperoleh dengan membagi biaya variabel total terhadap jumlah produksinya, atau $\mathbf{A V C}=\mathbf{T V C} / \mathbf{Q}$. sedangkan biaya keseluruhan per unit output (AC) dapat diperoleh dapat dengan membagi TC terhadap jumlah output yang dihasilkan ( $\mathbf{A C}=\mathbf{T C}$ / Q) atau dengan menjumlahkan besarnya AFC dan AVC.

Sedangkan biaya marginal (Marginal Cost $=\mathrm{MC}$ ) adalah perubahan biaya total yang diakibatkan oleh perubahan output sebesar satu init atau dapat dirumuskan sebagai berikut:

$$
M C=\frac{\Delta \mathrm{TC}}{\Delta \mathrm{Q}}
$$

Marginal cost sering didefinisikan sebagai perubahan biaya variabel yang diakibatkan oleh perubahan unit output. Hal ini disebabkan perubahan biaya variabel dan perubahan biaya total dalam jumlah yang sama. Untuk memperjelas hubungan antara masing-masing biaya dapat dilihat pada Tabel 7. 2.sebagai berikut:

Tabel 7. 2.Hubungan antara FC, VC, TC, AFC, AVC, AC dan MC

\begin{tabular}{|c|c|c|c|c|c|c|c|}
\hline Output (Q) & FC & VC & TC & AFC & AVC & AC & MC \\
\hline 0 & 55 & 0 & 55 & $*$ & 0 & $*$ & $*$ \\
1 & 55 & 30 & 85 & 55 & 30 & 85 & 30 \\
2 & 55 & 55 & 110 & 25,7 & 27,5 & 55 & 25 \\
3 & 55 & 75 & 130 & 18,3 & 25 & 43,3 & 20 \\
4 & 55 & 105 & 160 & 13,67 & 26,25 & 40 & 30 \\
5 & 55 & 155 & 210 & 11 & 31 & 42 & 50 \\
6 & 55 & 225 & 280 & 9,17 & 37,5 & 46,67 & 70 \\
7 & 55 & 315 & 370 & 7,86 & 45 & 52,86 & 90 \\
8 & 55 & 425 & 480 & 6,87 & 53,12 & 60 & 110 \\
9 & 55 & 555 & 610 & 6,1 & 61,67 & 67,77 & 130 \\
\hline
\end{tabular}

${ }^{*}=$ undefinied. 


\subsection{Hubungan Antara Produksi dan Biaya Produksi}

Biaya untuk memproduksi suatu barang yang harus dikeluarkan oleh produsen tergantung pada harga setiap unit input (faktor produksi), dan jumlah input yang digunakan dalam proses produksi tersebut. Semakin banyak jumlah input yang digunakan, akan semakin besar jumlah biaya yang dikeluarkan produsen tersebut. Ini berarti bahwa pada umumnya biaya produksi adalah konsekuensi ekonomi yang harus ditanggung seorang produsen jika ia megambil keputusan untuk melakukan aktivitas produksi. Biaya produksi yang dihadapi seorang produsen merupakan "nilai uang" atas pilihan penggunaan kombinasi input tertentu. Naik turunya kurva produksi (TPP, APP, atau MPP) akan tercermin pula pada kurva biaya produksi (TVC, AVC dan MC). Hubungan antara produksi dan biaya produksi dapat dijelaskan sebagai berikut.

Dalam proses produksi jangka pendek, yang mengasumsikan hanya ada satu input yang bersifat variabel (misal tenaga kerja) dan input lain dianggap tetap (misalnya tanah), maka proses produksi dapat ditunjukkan pada tabel 7. 3. sebagai berikut;

Tabel 7. 3. Hubungan Produksi dan Biaya Produksi (1)

\begin{tabular}{|c|c|c|c|c|}
\hline Tanah (Ha) & TK (orang) & TPP $(\mathrm{Kg})$ & APP & MPP \\
\hline 1 & 1 & 100 & 100 & - \\
1 & 2 & 300 & 150 & 200 \\
1 & 3 & 700 & 233 & 400 \\
1 & 4 & 1000 & 250 & 300 \\
1 & 5 & 1200 & 240 & 200 \\
1 & 6 & 1300 & 217 & 100 \\
1 & 7 & 1350 & 193 & 50 \\
\hline
\end{tabular}

Sumber: Salvatore, Dominic, Micro Economy Theory.

Selanjutnya jika dianggap harga satu unit tenaga kerja (berupa upah orang) adalah Rp. 300. 000,- per satuan waktu tertentu, dan harga satu hektar tanah (misal sewa) adalah Rp. 500. 000,- maka berbagai kemungkinan biaya yang dihadapi perusahaan adalah sebagai berikut: 
Tabel 7. 4. Hubungan Produksi dan Biaya Produksi (2).

\begin{tabular}{|c|c|r|r|r|r|r|r|c|}
\hline Tanah & TK & \multicolumn{1}{|c|}{ TPP } & FC & \multicolumn{1}{|c|}{ TVC } & \multicolumn{1}{|c|}{ TC } & AC & AVC & MC \\
\hline 1 & 1 & 100 & 500 & 300 & 800 & 8,00 & 3,00 & - \\
1 & 2 & 300 & 500 & 600 & 1100 & 3,67 & 2,00 & 1,50 \\
1 & 3 & 700 & 500 & 900 & 1400 & 2,00 & 1,29 & 0,75 \\
1 & 4 & 1000 & 500 & 1200 & 1700 & 1,70 & 1,20 & 1,00 \\
1 & 5 & 1200 & 500 & 1500 & 2000 & 1,67 & 1,25 & 1,50 \\
1 & 6 & 1300 & 500 & 1800 & 2300 & 1,77 & 1,38 & 3,00 \\
1 & 7 & 1350 & 500 & 2100 & 2600 & 1,93 & 1,56 & 6,00 \\
\hline
\end{tabular}

Sumber. Salvatore, Dominic, Micro Economy Theory

Hubungan antara fungsi-fungsi produksi dan fungsi-fungsi biaya dalam jangka pendek tersebut ditunjukkan oleh hubungan matematis sebagai berikut:

a. Hubungan antara AVC dengan $A P P_{L}$

$\operatorname{TPP}_{\mathrm{L}}=\mathrm{Q}=\mathrm{f}(\mathrm{L}) ;$ dan $A P P_{\mathrm{L}}=\mathrm{TP} / \mathrm{L}=\mathrm{Q} / \mathrm{L}$; jadi $\mathrm{Q}=A P P_{\mathrm{L}} . \mathrm{L}$

Sedangkan TVC $=w L$; dan $A V C=T V C / Q=w L / Q$;

jadi $A V C=W L / A P P_{L}$. L .

Atau $\mathbf{A V C}=\mathbf{w} / \mathbf{A P P}$; yang menunjukkan bahwa hubungan antara

$A V C$ dan $A P P_{L}$ adalah kebalikan (berlawanan). dimana:

$\operatorname{TPP}_{\mathrm{L}}=\mathrm{Q}=$ output (produk)

$\mathrm{L} \quad \quad=$ Tenaga kerja

$\mathrm{APP}_{\mathrm{L}} \quad=$ Produk rata-rata

TVC = Biaya variabel

$\mathrm{W} \quad=$ Tingkat Upah per orang

AVC = Biaya variabel rata-rata.

b. Hubungan antara MC dengan MPPL

$T P P L=Q=f(L)$;

$M P P_{L}=d T P / d L=d Q / d L ;$

jadi $d Q=M P P_{L} \cdot d L$

Sedangkan TVC $=w L$; dan $M C=d T V C / d Q=w d L / d Q$;

jadi $M C=W L / M P P_{L} \cdot d L$.

Atau $\mathbf{M C}=\mathbf{w} / \mathbf{M P P}_{\mathbf{L}}$;

Hal ini yang menunjukkan bahwa hubungan antara $M C$ dan $M P P_{L}$ adalah berbalikan (berlawanan) 
dimana:

$$
\begin{array}{ll}
\mathrm{TPP}_{\mathrm{L}}=\mathrm{Q} & =\text { output (produk) } \\
\mathrm{L} & =\text { Tenaga kerja } \\
\mathrm{MPP} & =\text { Produk Marginal } \\
\mathrm{TVC} & =\text { Biaya variabel } \\
\mathrm{W} & =\text { Tingkat Upah per orang } \\
\mathrm{MC} & =\text { Biaya Marginal. }
\end{array}
$$

\subsection{Proses Produksi dalam Jangka Panjang dan Biaya}

Dalam jangka panjang, semua faktor produksi yang digunakan dalam sebuah proses produksi bersifat variabel. Sehingga tidak lagi terdapat faktor produksi yang bersifat tetap. Jumlah output (maksimal) dalam proses produksi jangka panjang ini dapat dihasilkan melalui berbagai kombinasi faktor produksi yang digunakan. Untuk memudahkan pemahaman tetang produksi jangka panjang ini, berikut terdapat contoh sederhana.

Hubungan antara produksi dalam jangka panjang dengan biaya produksi adalah sebagai berikut. Ambil contoh barang output "A", sebesar $282 \mathrm{Kg}$. Dimisalkan sewa tanah Rp. 500. 000,- per hektare dan upah tenaga kerja Rp. 300. 000,- per orang. Hubungan tersebut dapat ditunjukkan pada tabel 7. 5. Untuk menghasilkan $282 \mathrm{Kg}$ barang "A". terdapat beberapa alternatif pembiayaan yaitu:

a. Menggunakan 4 hektare @ Rp.500.000,- + tenaga kerja 1 orang @ Rp. 300. 000,- = Rp. 2.300. 000,-

b. Menggunakan 2 hektare @ Rp.500.000,- + tenaga kerja 2 orang @ Rp. 300. 000,- = Rp. 1.600.000,-

c. Menggunakan 1 hektare @ Rp. 500.000,- + tenaga kerja 4 orang @ Rp. 300. 000,- = Rp. 1. 700. 000,-

Tabel. 7. 5. Skedul Produksi Jangka Panjang

\begin{tabular}{|c|c|r|c|r|c|}
\hline Output & Tanah & B. Sewa & TK (org) & B. Upah & B. Total \\
\hline 282 & 4 & 2.000 & 1 & 300 & 2.300 \\
282 & 2 & 1.000 & 2 & 600 & 1.600 \\
282 & 1 & 500 & 4 & 1.200 & 1.700 \\
\hline
\end{tabular}

Produsen yang rasional tentu memilih kombinasi input yang memiliki biaya paling rendah. Jika produsen memilih alternatif (b), maka 
lebih hemat Rp. 700. 000,- dibanding dengan alternatif (a), dan lebih hemat Rp. 100. 000,- dibandingkan aleternatif (c). alternatif (b) ini disebut "Least-Cost Faktor Combination".

\subsection{Latihan Soal}

1. a. Apakah sajakah komponen biaya implisit yang ditanggung pengusaha dalam mengoperasikan perusahaannya?

b. Bagaimana biaya implisit ini diperkirakan?

c. Mengapa biaya ini harus dimasukkan sebagai bagian dari biaya produksi?

d. Berapa harga yang harus dibayar perusahaan untuk membeli atau menyewa faktor produksi yang tidak dimilikinya?

2. a. Lengkapi tabel dibawah ini untuk mendapatkan skedul Total cost (TC), Fixed Cost (FC), Variabel Cost (VC), Average Fixed Cost (AFC), Average Variable Cost (AVC), Average Cost (AC) dan Marginal Cost (MC)

b. Pada grafik yang sama, gambarkanlah skedul TC, FC, VC, AFC, AVC, AC, dan MC

c. Jelaskan mengapa kurva-kurva tersebut mempunyai bentuk seperti yang telah anda gambarkan!

\begin{tabular}{|c|c|c|c|c|c|c|c|}
\hline Output (Q) & FC & VC & TC & AFC & AVC & AC & MC \\
\hline 0 & 60 & 0 & & & & & \\
1 & 60 & 30 & & & & & \\
2 & 60 & 40 & & & & & \\
3 & 60 & 45 & & & & & \\
4 & 60 & 55 & & & & & \\
5 & 60 & 75 & & & & & \\
6 & 60 & 120 & & & & & \\
\hline
\end{tabular}

3. a. Berikan beberapa contoh faktor produksi tetap dan variabel dalam jangka pendek!

b. Apakah hubungan antara jumlah input tetap yang digunakan dan tingkat output jangka pendek?

4. a. Apakah hubungan antara jangka panjang dan jangka pendek!

b. Bagaimana karakteristik variable dalam jangka pendek dan bagaimana pula dalam jangka panjang?

5. Lengkap tabel dibawah ini untuk mengetahui hubungan antara produksi dan biaya produksi 
b. Gambarkan skedul di dalam table dibawah ini

c. Dari point (a) dan (b) bagaimana hubungan antara produksi dan biaya produksi?

\begin{tabular}{|c|c|r|r|r|r|r|l|l|l|l|}
\hline Tanah & $\begin{array}{c}\text { TK } \\
(\mathrm{L})\end{array}$ & TPP & $\mathrm{AP}_{\mathrm{L}}$ & $\mathrm{MP}_{\mathrm{L}}$ & $\mathrm{FC}$ & $\mathrm{TVC}$ & $\mathrm{TC}$ & $\mathrm{AC}$ & $\mathrm{AVC}$ & $\mathrm{MC}$ \\
\hline 1 & 1 & 100 & & & 500 & 300 & & & & \\
1 & 2 & 300 & & & 500 & 600 & & & & \\
1 & 3 & 700 & & & 500 & 900 & & & & \\
1 & 4 & 1000 & & & 500 & 1200 & & & & \\
1 & 5 & 1200 & & & 500 & 1500 & & & & \\
1 & 6 & 1300 & & & 500 & 1800 & & & & \\
1 & 7 & 1350 & & & 500 & 2100 & & & & \\
\hline
\end{tabular}

\section{Istilah-istilah Penting ;}

Opportunity Cost

Constant Opportunity Cost and Inceasing Opportunity Cost

Biaya Ekplisit dan Implisit

Biaya total: Biaya tetap total \& Biaya variabel total

Biaya rata-rata, Biaya tetap rata, Biaya variabel rata-rata, Biaya marginal.

Harga faktor Produksi

Return to scale

Least cost Faktor Combination

Biaya produksi jangka pendek \& jangka panjang. 
84 


\section{BAB 8 \\ PASAR PERSAINGAN SEMPURNA}

\section{TUJUAN INSTRUKSIONAL KHUSUS}

1. Mahasiswa dapat menjelaskan perilaku perusahaan di pasar persaingan sempurna

2. Mahasiswa dapat menjelaskan hubungan antara total, average dan marginal revenue

3. Mahasiswa dapat menghitung tingkat keuntungan perusahaan

4. Mahasiswa dapat menjelaskan kebaikan dan keburukan pasar persaingan sempurna

\subsection{Pendahuluan}

Pada setiap pasar terdapat berbagai macam persaingan, baik persaingan yang sangat ketat, longgar, persaingan yang sangat lemah dan kuat serta yang sama sekali tanpa persiangan. Persaingan ini dapat berupa persingan antar pembeli atau persaingan antar penjual. Persaingan antar pembeli berupa kesediaan para pembeli untuk membeli dengan harga yang lebih tinggi untuk barang yang diinginkan. Pembeli dapat pula bersaing dengan bersedia dalam jumlah yang banyak untuk memperoleh harga yang lebih murah. Persaingan antar penjual dapat melalui berbagai cara, seperti melalui promosi penjualan, perbaikan mutu produk, pengembangan produk baru, pemasangan iklan dan perombakan produk yang sudah dianggap lama.

Persaingan antar penjual dalam teori ekonomi mikro dikenal dalam beberapa bentuk. Bentuk persaingan antar penjual ini akhirnya menghasilkan berbagai macam bentuk (jenis) pasar, yaitu pasar persingan sempurna, pasar monopoli, pasar oligopoli dan pasar monopolistik. Dua bentuk pasar yang paling ekstrim yaitu pasar persaingan sempurna dimana terdapat banyak penjual serta pembeli dan pasar monopoli dimana hanya ada satu produsen yang bertindak sebagai penjual. Bentuk pasar yang terletak diantara keduanya ini adalah pasar oligopoli dimana pasar hanya didominasi oleh beberapa penjual dan pasar monopolistik dimana banyak perusahaan yang bersaing dengan cara membuat produk yang berbeda. 


\subsection{Perilaku Perusahaan di Pasar Persaingan Sempurna}

Pasar persaingan sempurna didefinisikan sebagai suatu struktur pasar yang mempunyai ciri-ciri sebagai berikut:

1. Di dalam pasar terdapat banyak penjual dan pembeli, dimana masing-masing pembeli dan penjual tidak dapat mempengaruhi harga yang terjadi di pasar. Sehingga dapat dikatakan pembeli dan penjual adalah sebagai price taker, yang berarti apapun tindakan penjual di pasar tidak dapat mengubah harga di pasar karena harga di pasar ditentukan oleh interasksi antara penjual dan pembeli.

2. Semua penjual menghasilkan barang yang identik (homogen) dimana barang yang dihasilkan produsen benar-benar serupa sehingga konsumen dapat membeli dari penjual mana saja tanpa khawatir produk antar penjual ada perbedaan karena produk yang dihasilkan adalah saling subtitusi.

3. Setiap perusahaan mudah "masuk" dan "keluar" pasar. Jika seorang penjual mampu memperoleh keuntungan lebih, maka akan bayak penjual baru yang masuk ke dalam struktur pasar untuk menghasilkan barang yang sama dengan produsen sebelumnya sehingga akan semakin banyak penawaran yang terjadi dan begitu pula sebaliknya.

4. Setiap pembeli dan penjual memiliki informasi yang sempurna mengenai pasar. Pembeli dianggap mengetahui tingkat harga yang berlaku di pasar serta perubahan-perubahannya sehingga kondisi ini mengakibatkan para penjual tidak bisa menjual barangnya dengan harga yang lebih tinggi dari pada harga yang berlaku di pasar.

\subsection{Permintaan di Pasar Persaingan Sempurna}

Salah satu dari ciri pasar persainmgan sempurna adalah, setiap perusahaan tidak dapat menentukan harga (price taker). Harga yang terjadi di pasar adalah merupakan interaksi antara seluruh produsen dan konsumen di pasar. Ciri tersebut digambarkan oleh kurva permintaan sebagai berikut: 


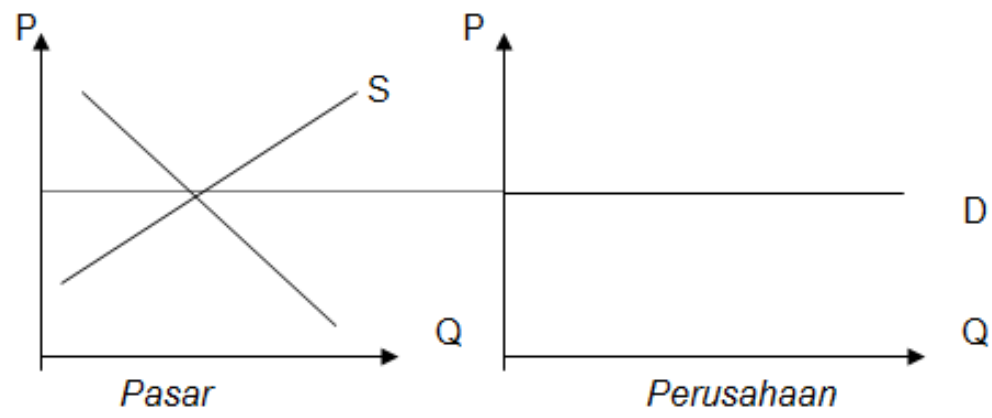

Gambar 8. 1. Kurva Permintaan pada Pasar Persaingan Sempurna

Kurva permintaan yang berbentuk horisontal tersebut memiliki implikasi sebagai berikut:

1. Hasil produksi semua perusahaan adalah semua homogen, dengan demikian apabila perusahaan tersebut menaikkan harga barang yang diproduksinya, maka tidak satupun produk yang terjual di pasar, dalam hal ini konsumen akan membeli produk perusahaan lain.

2. Jumlah produksi suatu perusahaan hanya merupakan sebagian kecil dari seluruh yang dijual di pasar, setiap perusahaan dapat menjual berapapun jumlah produknya pada harga yang berlaku di pasar dan tidak ada alasan bagi perusahaan tersebut untuk menaikkan atau menurunkan harga jualnya.

\subsection{Hubungan antara Total, Average dan Marginal Revenue}

Dalam perhitungan tingkat keuntungan yang diperoleh, sebuah perusahaan akan membandingkan antara penerimaan total yang diterimanya dan biaya total yang dikeluarkannya. Penerimaan total (Total Revenue $=T R$ ) merupakan perkalian antara jumlah output yang berhasil dijual dengan harga yang terjadi di pasar. Dari penerimaan total, bisa diperoleh penerimaan rata-rata (Average Revenue $=A R$ ) dan penerimaan Marginal (Marginal Revenue $=M R$ ). Penerimaan rata-rata dapat diperoleh dengan cara membagi penerimaan total dengan jumlah output yang berhasil dijual produsen, sedangkan penerimaan marginal diperoleh dengan mencari turunan pertama dari fungsi penerimaan total atau dengan cara menghitung perubahan penerimaan total dengan perubahan jumlah output.

Pada pasar persaingan sempurna, kurva permintaan berbentuk horisontal, dimana kurva permintaan tersebut menunjukkan bahwa ;

$\mathrm{D}=\mathrm{P}=\mathrm{AR}=\mathrm{MR}$. 
Dimana untuk penjelasan matematisnya adalah sebagai berikut:

Jika diketahui harga pasar $(P)$ sebesar 10 , maka $T R=P . Q=10 Q$

Besarnya $A R=T R / Q=10 Q / Q=10$.

Besarnya $M R=d T R / d Q=10$

Jadi dapat disimpulkan bahwa $D=A R=M R=P$.

\subsection{Maksimisasi Keuntungan}

Maksimisasi keuntungan adalah salah satu tujuan perusahaan dalam memproduksi suatu barang. Tujuan perusahaan yang lain di antaranya adalah maksimisasi penjualan, pertumbuhan perusahaan, dan kepuasan manajemen. Dalam jangka pendek, pemaksimuman keuntungan oleh produsen dapat diterangkan dengan dua pendekatan yaitu:

1. Pendekatan total, yaitu pendekatan dengan cara membandingkan hasil penerimaan total dengan biaya total.

2. Pendekatan marginal, yaitu pendekatan dengan cara membandingkan hasil penerimaan marginal sama dengan biaya marginal.

Untuk lebih mudahnya dapat dilihat pada Tabel 8.1. Pada tabel 8.1. produsen akan menjual produknya sebanyak 8 unit yaitu pada saat selisih antara TR dan TC adalah yang paling besar. Dengan tingkat harga yang terjadi di pasar sebesar 5 , maka produsen memperoleh keuntungan tertinggi sebanyak 7,5.

Tabel 8.1. Pendekatan Keuntungan Total

\begin{tabular}{|c|c|c|c|c|}
\hline $\mathrm{Q}$ & $\mathrm{P}$ & TR & TC & Total Keuntungan \\
\hline 1 & 5 & 5 & 17 & -12 \\
2 & 5 & 10 & 18,5 & $-8,5$ \\
3 & 5 & 15 & 19,5 & $-4,5$ \\
4 & 5 & 20 & 20,75 & $-0,75$ \\
5 & 5 & 25 & 22,25 & 2,75 \\
6 & 5 & 30 & 24,25 & 5,75 \\
7 & 5 & 35 & 27,5 & 7,5 \\
8 & 5 & 40 & 32,5 & 7,5 \\
9 & 5 & 45 & 40,5 & 4,5 \\
10 & 5 & 50 & 52,5 & $-2,5$ \\
\hline
\end{tabular}


Disamping pendekatan keuntungan total. Perhitungan maksimisasi keuntungan juga dapat dilakukan dengan menggunakan pendekatan marginal. Adapun komponen yang dibutuhkan adalah Jumlah output, nilai Marginal Revenue (MR) dan Marginal Cost (MC), Pada Tabel 8.2.dengan pendekatan marginal, dicari kondisi pada saat $\mathrm{MR}=\mathrm{MC}$ dimana pada kondisi tersebut jumlah output yang dihasilkan adalah 8 unit dan tingkat keuntungan maksimum yang diperoleh adalah sebesar 7,5 .

Tabel 8.2.Pendekatan Marginal

\begin{tabular}{|c|c|c|c|}
\hline $\mathrm{Q}$ & $\mathrm{P}=\mathrm{MR}$ & $\mathrm{MC}$ & Keuntungan Total \\
\hline 1 & 5 & - & -12 \\
2 & 5 & 1,5 & $-8,5$ \\
3 & 5 & 1 & $-4,5$ \\
4 & 5 & 1,25 & $-0,75$ \\
5 & 5 & 1,5 & 2,75 \\
6 & 5 & 2 & 5,75 \\
7 & 5 & 3,25 & 7,5 \\
8 & 5 & 5 & 7,5 \\
9 & 5 & 8 & 4,5 \\
10 & 5 & 12 & 2,5 \\
\hline
\end{tabular}

Penjelasan secara grafik adalah sebagai berikut:

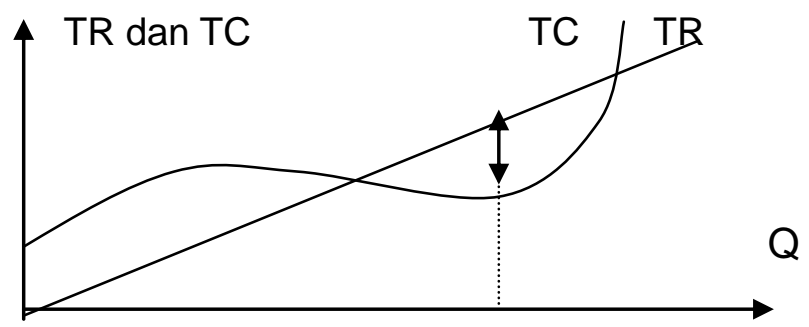

Gambar 8.2.Maksimasi Keuntungan

\subsection{Beberapa Kemungkinan Kedudukan Kegiatan Perusahaan}

Penjelasan pada bagian ini berpegang pada asumsi bahwa semua perusahaan beruapaya memenuhi salah satu tujuan, yaitu maksimisasi keuntungan dengan kriteria $\mathrm{MR}=\mathrm{MC}$. 
1. Kedudukan pertama adalah apabila perusahaan menawarkan produk dengan harga produk lebih besar dari pada biaya rata-rata minimum ( $P>A C$ minimum). Jika seorang produsen menjual pada saat harga yang terjadi di pasar melebihi biaya rata-rata minimum, maka produsen akan dapat memperoleh laba sebesar normal. Produsen masih memiliki sisa hasil penjualan walaupun semua kewajiban produsen sudah dipenuhi.

2. Kedudukan kedua adalah apabila perusahaan menawarkan produknya dengan harga produk yang sama dengan biaya rata-rata minimum ( $P=A C$ minimum). Jika harga pasar yang terjadi sama dengan besarnya biaya minimum yang harus dibayar, maka produsen hanya akan mendapatkan laba normal, dimana sisa penjualan tidak ada lagi minimum produsen sudah memenuhi semua kewajibannya.

3. Kedudukan perusahaan ketiga adalah apabila harga terletak antara biaya rata-rata variabel dan biaya yang minimum (AVC minimum $<A C$ $<$ minimum). Pada kondisi ini produsen mengalami kerugian, tetapi kerugian tersebut masih dapat diatasi (walaupun tetap rugi), karena produsen mendapat kelebihan harga di atas VC sehingga hanya mengalami kerugian yang lebih kecil dari biaya tetapnya.

4. Kedudukan perusahaan yang keempat adalah apabila harga sama dengan biaya rata-rata variabel yang minimum ( $\mathrm{A}=\mathrm{AVC}$ minimum). Kondisi ini disebut dengan shut down point, yaitu titik yang menunjukkan produsen boleh memilih antara tetap berproduksi atau tidak berproduksi, karena kerugian yang dialami adalah sama.

5. Kedudukan perusahaan yang kelima adalah jika harga yang terjadi lebih kecil dari pada biaya rata-rata variabel yang minimum $(P<A V C$ minimum). Apabila produsen dalam kondisi ini produsen mengalami kerugian sebesar FC. Oleh karena itu sebelum berada pada posisi ini maka sebaiknya perusahaan tutup, yaitu pada posisi $P=A V C$ minimum.

\subsection{Kondisi Pasar Persaingan Sempurna dalam Jangka Panjang}

Dalam jangka panjang, perusahan akan dapat menambah faktorfaktor produksi yang di dalam jangka pendek jumlahnya tetap sehingga hal ini mengakibatkan semua biaya yang dikeluarkan perusahaan bersifat variabel. Dalam jangka panjang akan banyak perusahaan yang masuk dan keluar pasar. Perusahaan baru akan memasuki pasar jika 
perusahaan baru tersebut melihat keuntungan seperti perusahaan sebelumnya. Sebaliknya, beberapa perusahaan yang tidak efisien akan meninggalkan pasar kalau perusahaan yang beropersi dipasar persaingan sempurna tersebut tidak bisa memperoleh keuntungan bahkan tidak lagi bisa menutup ongkos variabelnya.

Sebaliknya jika permintan suatu barang pada pasar persaingan sempurna berkurang, maka kondisi ini akan menurunkan tingkat harga dan tingkat keuntungan yang diperoleh perusahaan yang beroprasi di pasar. Jika harga yang terjadi lebih rendah dari biaya rata-ratanya, maka beberapa perusahaan mulai bangkrut. Perusahaan ini lebih baik keuar dari pasar dari pada menanggung kerugian. Keluarnya beberapa perusahaan akan membuat jumlah penawaran menjadi berkurang. Hal ini tentunya akan menaikkan harga. Selama kenaikan harga yang terjadi belum memberikan keuntungan bagi produsen, maka masih akan ada perusahaan yang keluar dari pasar. Kondisi ini berhenti jika produsen baru memperoleh keuntungan normal. Jadi kesimpulannya, dalam jangka panjang produsen dalam pasar persaingan sempurna hanya akan memperoleh laba normal.

\subsection{Kebaikan dan Keburukan Pasar Persaingan Sempurna}

A. Kebaikan Pasar Persaingan Sempurna.

1. Dalam jangka panjang akan terjadi efisiensi produksi. karena jangka panjang perusahaan hanya mendapatkan laba normal, dimana laba normal terjadi jika harga sama dengan biaya produksi terendah.

2. Didalam pasar persaingan sempurna setiap pembeli dan penjual memiliki kebebasan bertindak dan memilih.

B. Keburukan Pasar Persaingan Sempurna.

1. Tidak mendorong inovasi, mudahnya perusahaan baru yang masuk dan meniru produk-produk yang sudah ada membuat enggan produsen untuk melakukan inovasi karena produsen lain akan mudah meniru produk inovasi tersebut.

2. Membatasi pilihan konsumen, barang-barang yang dihasilkan produsen pada pasar persaingan sempurna identik satu sama lain sehingga memiliki pilihan yang terbatas dalam menentukan barang yang dikonsumsinya. Pilihan yang terbatas akan mengakibatkan ada banyak kebutuhan yang belum dapat terpenuhi. 


\subsection{Latihan Soal}

1. Jelaskan secara terinci ciri-ciri dari pasar persaingan sempurna!

2. Bagaimana bentuk kurva permintaan dalam pasar persaingan sempurna? Gambar dan jelaskan!

3. Seorang pengusaha pabrik tertentu menganggap bahwa dalam posisi yang sangat bersaing karena ia sangat menyadari persaingannya dengan beberapa pengusaha pabrik mobil lainnya di dalam pasar. Seperti pengusaha pabrik mobil lainnya, ia melaksanakan berbagai promosi periklanan yang aktif mencoba meyakinkan beberapa pembeli potensial untuk mobil-mobilnya yang berkualitas tinggi dengan model yang futuristic dan bereaksi sangat cepat dalam mengantisipasi berbagai tuntungan keunggulan oleh beberapa pesaingnnya. Inikah yang disebut dengan model persaingan sempurna menurut para ahli ekonomi?

4. Dari tabel dibawah, carilah:

a. Carilah MR, AC, keuntungan per unit dan keuntungan total pada setiap tingkat output.

b. Pada satu grafik, gambarkan skedul d, MR, MC dan AC. Berilah tanda $A$ untuk titik dimana kerugian total mencapai maksimum. B' dan E' untuk titik pulang pokok, C' untuk titik dimana keuntungan per unit mencapai maksimum dan $D^{\prime}$ untuk titik dimana keuntungan total adalah maksimum

c. Berikan penjelasan pada grafik yang dihasilkan pada bagian (b)

\begin{tabular}{|l|l|l|l|l|l|}
\hline \multicolumn{1}{|c|}{$\mathrm{Q}$} & $\mathrm{P}$ & \multicolumn{1}{|c|}{ TR } & \multicolumn{1}{c|}{ TC } & Profit & Cat \\
\hline 0 & 4 & 0 & 400 & -400 & \\
\hline 100 & 4 & 400 & 1000 & -600 & Total kerugian maksimum \\
\hline 200 & 4 & 800 & 1300 & -500 & \\
\hline 300 & 4 & 1200 & 1500 & -300 & \\
\hline 400 & 4 & 1600 & 1600 & 0 & Titik pulang pokok \\
\hline 500 & 4 & 2000 & 1700 & +300 & \\
\hline 600 & 4 & 2400 & 1850 & +550 & \\
\hline 700 & 4 & 2800 & 2100 & +700 & \\
\hline 750 & 4 & 3000 & 2265 & +735 & Total keuntungan maksimum \\
\hline 800 & 4 & 3200 & 2500 & +700 & \\
\hline 900 & 4 & 3600 & 3800 & 0 & Titik pulang pokok \\
\hline
\end{tabular}


Istilah-istilah Penting ;

Price Taker

Total Revenue

Average Revenue

Marginal Revenue

Shut down Point

Inovasi. 
94 


\section{BAB 9 \\ PASAR MONOPOLI}

\section{TUJUAN INSTRUKSIONAL KHUSUS}

1. Mahasiswa dapat menjelaskan perilaku perusahaan di pasar monopoli

2. Mahasiswa dapat menjelaskan penyebab terjadi pasar monopoli

3. Mahasiswa dapat menghitung tingkat keuntungan perusahaan pada pasar monopoli

4. Mahasiswa dapat menjelaskan dampak dari praktik monopoli

\subsection{Pengertian Monopoli}

Dalam kehidupan perekonomian faktual, kita sangat jarang mendapatkan penjual yang tidak menghadapi persaingan dari penjual lain. Meskipun dalam satu pasar misalnya hanya terdapat satu penjual sehingga tidak ada persaingan secara langsung dari penjual lain, tetapi penjual tunggal tersebut akan menghadapi persaingan secara tidak langsung dari penjual lain yang menjual produk yang dapat menjadi alternatif produk pengganti yang tidak sempurna. Dalam pasar monopoli adalah suatu pasar dimana hanya ada satu penjual dari suatu produk (barang atau jasa) yang tidak mempunyai alternatif produk pengganti (subtitusi) maka dalam pasar monopoli tidak ada pesaing dari penjual lain.

\subsection{Sebab-Sebab Monopoli}

Penjual dapat menjadi penjual tunggal (monopoli) yang tidak mempunyai alternatif produk (pengganti) karena di dalam pasar penjual tunggal barada, terdapat faktor-faktor yang mencegah penjual-penjual lain masuk pasar tersebut yang disebut dengan faktor penghambat (barrier to entry) ada dua jenis faktor penghambat ini; (1) faktor penghambat tehnis (technical barrier to entry), (2) faktor penghambat legal (legal barirer to entry). 


\section{Faktor Penghambat Teknis:}

1. Apabila penjual tunggal menghasilkan dan menjual produk dengan kondisi biaya marginal $(\mathrm{MC})$ dan biaya rata-rata $(\mathrm{AC})$ yang menurun pada berbagai kemungkinan tingkat produk. Kondisi MC dan AC yang menurun terjadi karena penjual dalam menghasilkan produk menggunakan teknologi sehingga kegiatan produksi menjadi lebih efisien.

2. Terjadi karena terbatasnya pasar dibandingkan dengan skala produksi penjual. Terbatasnya pasar akan memberikan ruang gerak yang sempit yang hanya akan memberikan ruang hidup yang hanya cukup untuk satu penjual saja. Oleh karena itu, dengan skala produksi penjual yang minimum tetapi terdapat keterbatasan pasar sehingga permintaan pasar dapat dipenuhi oleh satu penjual saja.

3. Terjadi karena penguasaan Faktor produksi yang strategis yang digunakan dalam menghasilkan produk.

Ketiga faktor penghambat tehnis dapat terjadi pada penjual yang mampu menghasilkan produk dengan cara yang inovatif, misalnya dengan cara menemukan teknologi baru, dan menemukan faktor produksi baru.

\section{Faktor penghambat Legal (Legal barrier to entry)}

1. Terjadi apabila penjual tunggal menghasilkan dan menjual produk dengan mendapatkan hak monopoli dari pemerintah untuk menghasilkan dan menjual produk tersebut. Pemberian hak monopoli oleh pemerintah berarti telah menutup kemungkinan perusahaan lain untuk memasuki dan menjual produknya pada pasar tersebut.

2. Terjadi apabila penjual tunggal menghasilkan produk dengan pemberian hak paten oleh pemerintah untuk menghasilkan produk tersebut. Hak paten adalah hak yang diberikan pemerintah kepada produsen yang menemukan sesuatu yang teramat sangat bermanfaat bagi produsen, seperti cara memproduksi yang baru, menemukan teknologi yang baru, dan menemukan faktor produksi yang baru.

3. Terjadi apabila penjual tunggal menghasilkan produk dengan memberikan franchise atau lisensi oleh penjual lain untuk menghasilkan produk dengan merek tersebut dalam suatu wilayah. Hak frinchise adalah hak yang diberikan oleh penjual lain kepada penjual atau produsen untuk menghasilkan produk dengan merek 
pemberi hak dalam suatu wilayah. Pemberian hak frichise oleh penjual lain kepada satu penjual dengan merek pemberi hak di suatu wilayah berarti akan menutup kemungkinan penjual lainnya untuk menghasilkan produk tersebut.

\subsection{Maksimisasi Keuntungan}

Dalam pasar monopoli, jumlah penjual adalah tunggal (satu penjual) dari satu produk (barang dan jasa) yang tidak mempunyai alternatif produk pengganti (subtitusi). Oleh karena itu, penjual dalam pasar monopoli selain menentukan jumlah produk yang dihasilkan juga menentukan tingkat harga jual yang dapat memaksimumkan keuntungan. Penentuan harga jual oleh produsen monopolist disebut price taker. Karena sebagai produsen tunggal di pasar, maka kurve permintaan yang dihadapi oleh produsen monopolist adalah kurve permintaan pasar yang menurun dari kiri atas ke kanan bawah, artinya produsen monopolist dapat mempengaruhi harga pasar dengan menjual lebih sedkit atau lebih banyak produk yang dihasilkan.

Kurva permintaan pasar yang miring negatif mengakibatkan penerimaan marginal (marginal revenue atau MR) lebih kecil dari pada harga. Untuk produk yang menunjukkan besarnya penerimaan marginal sama dengan biaya marginal (marginal Cost atau MC). Hal ini mengakibatkan produsen monopolist akan menghasilkan tingkat produk yang menunjukkan harga pasar melebihi biaya marginal. Maksimisasi keuntungan dalam pasar monopoli dapat dijelasakan dengan menggunakan pendekatan total dan marginal seperti yang ditunjukkan dalam Tabel 9.1. sebagai berikut;

Tabel 9.1. Maksimisasi Keuntungan dalam Pasar Monopoli dengan Pendekatan Total dan Pendepatan Marginal

\begin{tabular}{|c|c|c|c|c|c|c|c|}
\hline Unit & Harga & TR & TC & Keuntungan & MR & MC & Ket. \\
\hline 1 & 180 & 180 & 175 & +5 & 180 & 30 & MR $>$ MC \\
2 & 160 & 320 & 200 & +120 & 140 & 25 & MR $>$ MC \\
3 & 140 & 420 & 220 & +200 & 100 & 20 & MR $>$ MC \\
4 & 120 & 480 & 280 & +230 & 60 & 60 & $M R=M C$ \\
5 & 100 & 500 & 345 & +155 & 20 & 65 & $M R<M C$ \\
6 & 80 & 480 & 415 & +65 & -20 & 70 & $M R<M C$ \\
7 & 60 & 420 & 505 & -85 & -60 & 90 & $M R<M C$ \\
8 & 40 & 320 & 615 & -295 & -100 & 110 & MR $<M C$ \\
\hline
\end{tabular}


Dalam pasar monopoli, kurve permintaan yang dihadapi produsen monopolist adalah juga kurve permintaan pasar yang menurun dari kiri atas ke kanan bawah, artinya produsen monopolist dapat mempengaruhi harga pasar dengan menjual lebih sedikit atau lebih banyak produk yang dihasilkan. Oleh karena itu, bentuk kurva TR seperti kurva parabola yang membuka ke bawah dan mempunyai titik puncak.

Sebagaimana disebutkan di atas bahwa pasar monopoli adalah salah satu pasar persaingan tidak sempurna. Pada pasar jenis ini hanya ada satu penjual, tidak ada barang substitusi dan adanya hambatan untuk masuk pasar. Dalam prakteknya, jarang sekali ditemukan pasar monopoli. Konsep "monopoli" dipergunakan untuk menunjukkan tingkat kekuatan pasar dari pelaku ekonomi yang terlibat.

Konsep monopoli fokus pada dua aspek yaitu: 1) tidak ada barang pengganti/substitusi dan 2) adanya hambatan untuk masuk pasar. Aspek yang pertama dapat dievaluasi dengan melihat nilai elastisitas silang dari permintaan yang dapat mengetahui apakah barang tersebut mempunyai produk pengganti atau tidak. Sedangkan hambatan untuk masuk pasar dapat ditinjau dari beberapa aspek yang sudah dijelaskan di depan.

Secara grafik, pasar monopoli dijelaskan pada Gambar 9.1. Gambar tersebut menunjukkan bahwa total revenue (TR) akan meningkat sampai output mencapai titik QT, setelah itu TR akan menurun. Perlu diketahui bahwa kemiringan negatif dari kurva permintaan adalah elastis pada tingkat harga yang tinggi dan inelastis pada tingkat harga yang rendah.

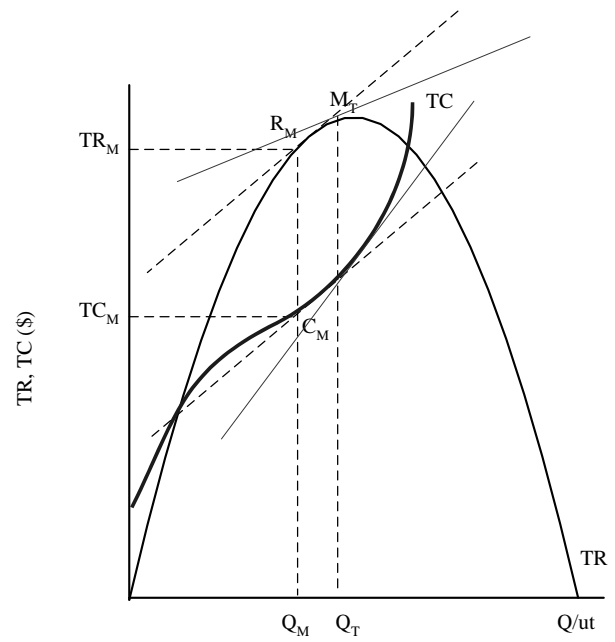

Gambar 9.1. Maksimisasi Keuntungan dari Sebuah Perusahaan pada Pasar Monopoli 
Untuk kurva Total Cost, nilainya meningkat dengan tingkat pertambahan yang semakin menurun pada fase sebelum titik balik dan meningkat dengan tingkat pertambahan yang semakin meningkat pada fase setelah titik balik.

Dengan menggunakan kurva TR dan TC, titik keuntungan maksimum dapat diidentifikasi. Titik ini terjadi pada saat $Q_{M}$ dimana $T R>$ TC dan jarak vertical antara TR dan TC adalah yang terpanjang. Pada Gambar 9.1. profit maksimum ditunjukkan dengan jarak antara $C_{M} R_{M}$, atau $\mathrm{TR}_{\mathrm{M}}-\mathrm{TC}_{\mathrm{M}}$.

Kemiringan dari TC atau Marginal Cost (MC) pada titik $C_{M}$ adalah sama dengan slope dari TR atau Marginal Revenue (MR) pada titik $R_{M}$ dengan tingkat produksi $Q_{M}$. Karena $M C=M R$, maka keuntungan maksimum tercapai pada titik $Q_{M}$. Jika perusahaan meningkatkan output dari $Q_{M}$ ke $Q_{T}$, nilai maksimum TR akan terjadi pada titik $M_{T}$ dan level output sebesar $Q_{T}$ tetapi tingkat keuntungan akan menurun karena biaya karena penambahan output $\left(\mathrm{Q}_{\mathrm{T}}-\mathrm{Q}_{\mathrm{M}}\right)$ adalah lebih besar daripada penambahan revenue atau $M C>M R$.

Sebagaimana ditunjukkan pada Gambar 9.2., jika permintaan dan average revenue (AR) adalah negatif, maka slope marginal revenue (MR) adalah dua kali dari AR dan titik perpotongan dengan axis berada pada titik ditengah-tengah titik asal dan AR. Ketika $M C=M R$ (pada titik Z) maka tingkat produksinya adalah $Q_{H}$ dan perusahaan akan memaksimalkan keuntungan. Sekalipun pembeli mau dan mampu membayar pada harga $P_{H}$ untuk tingkat produksi sebesar $Q_{H}$, tetapi mereka tidak mau membayar kalau tidak ada diskriminasi harga. Sebaliknya mereka mau membayar lebih untuk produk dari titik asal (nol) sampai dengan $Q_{H}$. Keuntungan direpresentasikan dengan area $C_{F} F H P_{H}$ atau $\left(P_{H}-C_{F}\right) Q_{H}$ jika tingkat biaya per unit adalah $C F$ dan keuntungan berada di atas normal. Hambatan untuk masuk pasar akan mencegah masuknya kompetitor ke dalam pasar dan mempertahankan keuntungan yang sangat besar. 


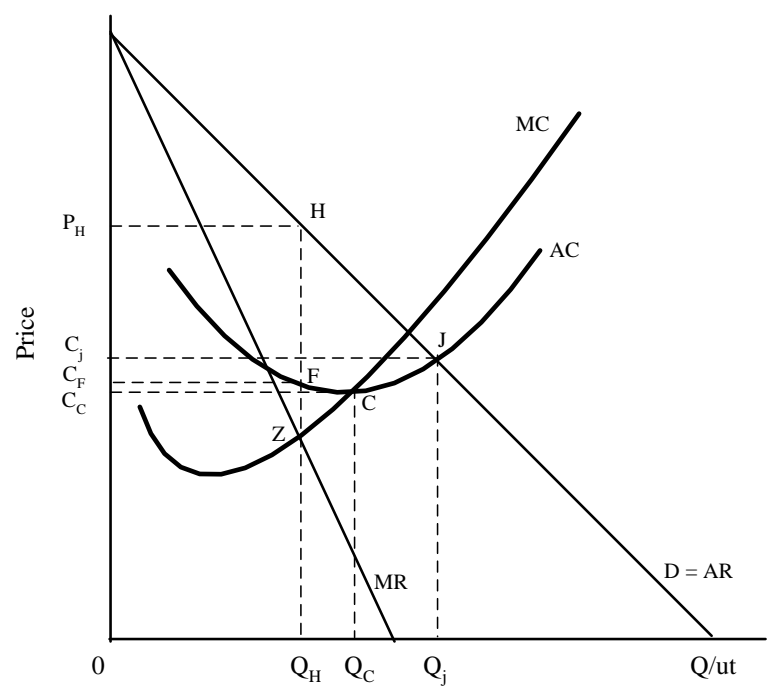

Gambar 9.2.Fungsi Penerimaan dan Biaya untuk Pelaku Monopoli

\subsection{Kebijakan Diskriminasi Harga}

Keuntungan monopolist akan diperoleh produsen monopolist secara terus menerus selama hambatan teknis dan legal dipertahankan sehinbgga tidak memungkinkan produsen lain memasuki pasar monopoli. Walaupun sudah memperoleh keuntungan monopolist, tetapi perusahaan monopoli masih dapat meningkatkan keuntungan maksimum yang diperolehnya dengan dengan menggunakan diskriminasi harga. Kebijakan diskriminasi harga adalah kebijakan produsen dalam pasar monopoli untuk memaksimumkan keuntungan yang dilakukan dengan cara dengan menjual produk yang sama pada pasar yang berbeda (harga yang berbeda) dengan cara yang efektif sehingga pembeli tidak dapat berpindah dari pasar yang satu ke pasar yang lain. Dengan demikian, keputusan dalam kebijakan diskriminasi harga adalah menjual produk di setiap pasar dengan kondisi penerimaan marginal sama dengan biaya marginal. Hal ini akan mengakibatkan harga yang berbeda untuk produk yang sama di kedua pasar. 


\subsection{Kurva Penawaran Produsen dalam Pasar Monopoli}

Pada waktu membahas pasar persaingan sempurna dihasilkan kesimpulan bahwa kurva penawaran produsen adalah bagian kurva biaya marginal (MC) yang terletak di atas biaya rata-rata (AVC) minimum. Kurva penewaran tersebut diperoleh dengan menggeser kurva prmnintaan pasar yang horisontal sejajar dengan sumbu jumlah produk yang dihasilkan yang kenmmudian akan diperoleh kurva penawaran melalui rangkaian kombinasi jumlah dan harga keseimbangan.

Cara memperoleh kurva penawaran seperti dalam pasar persaingan sempurna tidak dapat dilakukkajn dalam pasar monopoli. Dengan kurva permintaan yang tetap, maka kurva penawaran dalam pasar monpoli hanya akan berupa satu titik, yaitu pada tingkat produk dimana penerimaan marginal sama dengan biaya marginal. Apabila kurva permintaan pasar bergeser maka kurva permintaan marginal juga akan bergeser, dan produsen monopolist akan memilih lagi tingkat produk yang menghasilkan keuntungan. Menghubungkan rangkaian titik keseimbangan yang dihasilkan dari pergeseran permintan tidak memberikan arti. Oleh karena itu, kurva penawaran dalam pasar monopoli tidak dapat dirumuskan dengan baik.

\subsection{Dampak Monopoli}

Produsen monopolist sering kali mendapatkan cercaaan dalam masyarakat karena banyak merugikan. Untuk mencegah kerugian yang dialami masyarakat, pemerintah melarang pendirian produsen monopollist atau usaha-usaha yang menjurus ke arah monop[oli, yaitu dengan membuat perangkat hukum (undang-undang). Beberapa kerugian yang dialami masyarakat, antara lain produsen monopolist nmemperoleh keuntungan lebih, memberikan layanan yang buruk dan tidak ada reaksi, mengeksploitasi pembeli dan pemilik faktor produksi.

Dalam pasar monopoli yang hanya ada satu penjual dari suatu produk (barang atau jasa) yang tidak mempunyai alternatif produk pengganti, penjual dalam pasar monopoli harus menetukan tingkat harga jual yang dapat memaksimumkan keuntungan. Penentuan tingkat harga jual oleh produsen monopolist akan mengakibatkan penerimaan keuntungan produsen yang lebih dari pada keuntungaan normal karena menerima keuntungan yang lebih besar dari pada produsen lainnya. Disamping itu, karena tidak ada produsen lain yang menghasilkan produk subtitusi maka produsen monopolist dapat saja dengan 
semaunya dengan tidak memperhatikan kritik dan saran pembeli. Sebagai contoh, kritik dan saran yang berkaitan dengan peningkatan kualitas produk yang dihasilkan tidak akan memperoleh reaksi produsen monopolist karena hanya dengan kualitas yang seperti itupun konsumen tetap ada yang mau membeli.

\subsection{Latihan Soal}

1. Sebutkan definisi dari pasar monopoli dan apa perbedaannya dengan pasar persaingan sempurna?

2. Apakah kondisi yang memungkinkan timbulnya monopoli?

3. Berdasarkan tabel dibawah ini:

a. Lengkapi skedul TR dan MR

b. Gambarkan kurva D dan MR pada pasar monopoli berdasarkan hasil point (a)

\begin{tabular}{|c|c|l|l|}
\hline $\mathrm{P}$ & $\mathrm{Q}$ & TR & MR \\
\hline 8 & 0 & & \\
\hline 7 & 1 & & \\
\hline 6 & 2 & & \\
\hline 5.5 & 2.5 & & \\
\hline 5 & 3 & & \\
\hline 4 & 4 & & \\
\hline 3 & 5 & & \\
\hline 2 & 6 & & \\
\hline 1 & 7 & & \\
\hline 0 & 8 & & \\
\hline
\end{tabular}

4. Bila fungsi $D$ adalah $Q D=12-P$

a. Carilah skedul D dan MR

b. Gambarkan skedul D dan MR

c. Carilah MR apabila $P=\$ 10, \$ 6$ dan $\$ 2$

\begin{tabular}{|c|c|c|c|c|c|c|c|c|c|c|c|c|c|}
\hline $\mathrm{P}$ & 12 & 11 & 10 & 9 & 8 & 7 & 6 & 5 & 4 & 3 & 2 & 1 & 0 \\
\hline $\mathrm{Q}$ & & & & & & & & & & & & & \\
\hline $\mathrm{TR}$ & & & & & & & & & & & & & \\
\hline $\mathrm{MR}$ & & & & & & & & & & & & & \\
\hline
\end{tabular}




\section{Istilah-istilah Penting;}

Pasar monopoli

Barrier to entry

Techncal and Legal barrier to entry

Monopolist

Monopsoni

Hak Franchise

Price Maker

Excess Profit. 
104 


\section{BAB 10 \\ PASAR OLIGOPOLI}

\section{TUJUAN INSTRUKSIONAL KHUSUS}

1. Mahasiswa dapat menjelaskan perilaku perusahaan di pasar oligopoly

2. Mahasiswa dapat mendefinisikan dan menjelaskan arti dari oligopoly

3. Mahasiswa dapat menjelaskan model cournot dan mengintepretasikannya

4. Mahasiswa memahami praktek kartel

5. Mahasiswa dapat menjelaskan kebaikan dan keburukan pasar oligopoli

\subsection{Arti Oligopoli}

Oligopoli adalah keadaan dimana hanya ada beberapa (misal antara 2 - 10) perusahaan yang mengusai pasar baik secara independen (sendiri-sendiri) maupun secara diam-diam bekerja sama. Oligopoli dapat dibedakan antara oligopoli dengan deferensiasi produk dan oligopoli tanpa deferensiasi produk. Ada tidaknya produk diferensiasi mempengaruhi sampai seberapa jumlah permintaan untuk produk suatu perusahaan tergantung pada perusahaan-perusahaan lain. Semakin besar tingkat deferensiasi produk yang ada, semakin tidak tergatung kurva permintaan suatu perusahaan pada pada perilaku perusahaan lain.

Tingkat "ketergantungan" antara perusahaan satu dengan perusahaan lain ini mempunyai implikasi terhadap kurva permintaan seorang oligopolist. Semakin kecil ketergantungan tersebut semakin bisa lebih pasti digambarkan kurva permintaannya. Sebaliknya bila tingkat ketergantungan tersebut besar, pada prinsipnya kita tidak bisa menggambarkan suatu kurva untuk seorang produsen oligopoli, kecuali kalau kita tahu perilaku atau macam reaksi apa yang akan dilakukan produsen-produsen lain bila produsen kita tersebut mengubah harga jualnya atau tingkat outputnya. Dan kemungkinan macam reaksi produsen-produsen lain adalah begitu luasnya, sehingga analisa 
mengenai perilaku produsen dalam industri oligopoli tanpa ada deferensiasi produk harus mengambil asumsi-asumsi yang menyederhanakan mengenai reaksi perusahaan-perusahaan lain. Tanpa adanya asumsi ini maka tidak bisa dilakukan analisa. Bagi oligopolist dengan diferensiasi produk yang kuat kita bisa dengan lebih mudah dan mantap menggambarkan kurva permintaan bagi seorang produsen, meskipun masih ada ketidak pastian posisi kurva permintaan bagi seorang produsen.

Adapun karakteristik dari pasar oligopoly adalah:

a. Sejumlah kecil dari perusahaan besar mempunyai kekuatan dan mampu mengontrol pasar.

b. Industri terdiri dari beberapa perusahaan

c. Adanya hambatan yang besar untuk memasuki pasar

d. Output dapat bersifat homogeny atau heterogen

e. Tidak ada kompetisi harga

f. Harga pasar cenderung stabil

g. Ada kemungkinan kolusi antar perusahaan

h. Adanya insentif ekonomi

i. Adanya ketergantungan yang tinggi antar perusahaan

\subsection{Output dan Harga dalam Oligopoli}

Kita melihat bahwa posisi equlibrium (keseimbangan) dari seorang produsen oligopoli sangat peka terhadap perilaku produsenprodusen lain, terutama bila perilaku ini menyangkut perubahan dari harga jual. Oleh karena itu perusahaan-perusahaan oloigopoli biasanya sadar betapa pentingnya untuk bisa bersetuju (kompak) mengenai harga jual dengan para pesaingnya (baik secara tidak langsung, diam-diam, atupun bila undang-undang memperkenankan, dalam bentuk kerjasama atau asosiasi yang terbuka antara mereka). Bila ini tercapai, maka ketidakpastian dan kesetabilan yang dihadapi oleh produsen-produsen oligopolist akan berkurang.

\subsection{Dampak Oligopoli}

Dampak negatif yang dapat ditimbulkan dari pasar oligopoli adalah dalam bentuk ;

1. Kemungkinan adanya keuntungan yang terlalu besar (Excess profit) yang dinikmati oleh produsen oligopoli dalam jangka panjang. 
2. Kemungkinan adanya ketidakefisienan produksi karena setiap produsen tidak beroprasi pada AC minimum.

3. Kemungkianan adanya eksploitasi konsumen atau buruh (karena $\mathrm{P}>\mathrm{MC}$; seperti kasus monopoli)

4. Ketegaran harga (terutama ke bawah) sering dikatakan menunjang adanya inflasi yang kronis; dan ini merugikan masyarakat secara makro.

Sementara itu dampak positif dari pasar oligopoli adalah adanya inovasi dan penerapan teknologi baru yang paling pesat. Hal ini disebabkan perusahaan-perusahaan tersebut cukup besar dan mampu untuk menyediakan dana untuk melakukan pengembangan dan penelitian; karena unsur persaingan antar perusahaan adalah cukup kuat (meskipun tidak dalam bentuk persaingan harga), sehingga dorongan untuk berlomba dibidang penemuan untuk proses produksi baru, produk baru dan penurunan ongkos produksi, cukup kuat pula bahkan lebih kuat dari kasus perusahaan monopoli.

Untuk menguragi efek-negatif dari pasar oligopoli ini ada beberapa kebijakan yang dapat diambil oleh pemerintah, yaitu ;

1. Pemerintah harus menjaga agar hambatan-hambatan bagi perusahaan baru untuk masuk kedalam industri/pasar oligopoli tersebut ditekan sampai sekecil-kecilnya. Tujuannya adalah agar perusahaan-perusahaan oligopoli yang telah ada merasakan adanya persaingan potensial yang lebih kuat sehingga mendorong mereka untuk berperilaku lebih kompetitif dibidang harga maupun non harga.

2. Diadakannya undang-undang yang melarang adanya kerja sama di antara para pengusaha oligopoli baik secara diam-diam atau kerja sama (collusion).

3. Kemungkinan kebijaksanaan yang lebih drastis adalah mencoba merombak struktur pasar yang oligopolistis tersebut antara lain dengan menentukan batas maksimum dari ukuran suatu badan usaha dan melarang diadakannya penggabungan (merger) antara perusahaan-perusahaan yang telah ada.

\subsection{Model Cournot}

Dalam model Cournot, kita mulai dengan asumsi bahwa terdapat dua perusahaan yang menjual air murni dalam kondisi biaya produksi nol. Oleh karena itu, tingkat penjualan yang memaksimumkan keuntungan bagi tiap perusahaan terjadi pada titik tengah kurva 
permintaannya yang berbentuk lurus dan mempunyai kemiringan negative, dimana nilai elastisitas adalah 1 dan TR adalah maksimum.

Asumsi perilaku dasar yang dibuat oleh Cournot adalah bahwa setiap perusahaan dalam usahanya memaksimumkan keuntungan total atau TR, mengasumsikan bahwa perusahaan lain akan mempertahankan output mereka pada tingkat yang konstan. Akibatnya adalah siklus perpindahan dan balasan oleh duoplolis tersebut sampai masing-masing menjual sepertiga dari total output industri. Gambar 10.1. mengilustrasikan bekerja Model Cournot.

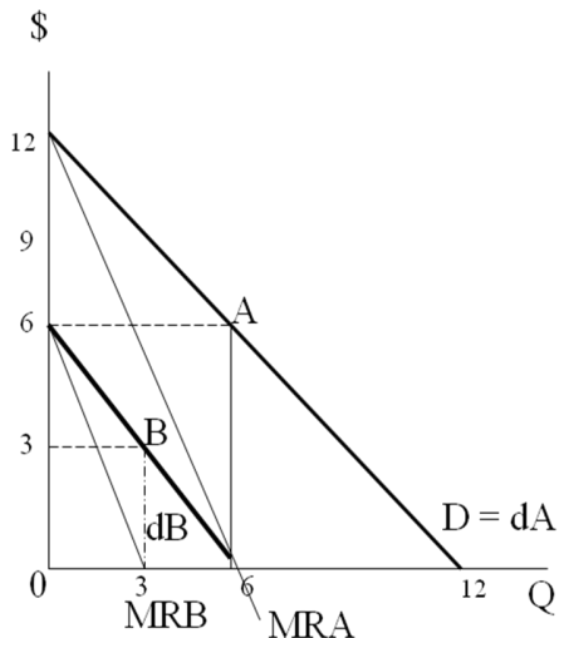

Gambar 10.1. Model Cournot

Gambar 10.1. menunjukkan kurva permintaan pasar atas air dari sumber mata air. Pada kondisi ini diasumsikan biaya marginal produksi perusahaan $A$ dianggap nol ketika hanya ada perusahaan $A$ di pasar, sehingga $D=d A$ dan perusahaan $A$ memaksimumkan laba dengan menjual sejumlah $Q=6$ pada $P=\$ 6$ (titik $A$ diperoleh dari $M R A=M C=$ $0)$.

Ketika perusahaan B masuk ke pasar, perusahaan ini akan menghadapi $\mathrm{dB}$ yang diberikan dengan pergeseran kurva permintaan pasar D ke kiri sebesar 6 unit yang dijual perusahaan A. Perusahaan B memaksimalkan laba dengan menjual $Q=3$ pada $P=\$ 3$ (titik $B$ diperoleh dari $M R B=M C=0$ ). Duopolis $A$ menghadap d'A yang diperoleh dari $D$ dikurang 3 dan memaksimalkan laba dengan menjual $Q$ $=4$. 5 , pada $P=\$ 4$. 5. Proses ini berlanjut sampai proses duopolis dengan menjual $Q=4$, dan $P=\$ 6$ 


\subsection{Kesepakatan Kartel}

Kesepakatan kartel adalah perusahaan berkolusi untuk membatasi atau mengurangi persaingan dalam rangka meningkatkan laba. Adapun contoh-contoh kartel adalah sebagai berikut: 1) Asosiasi perusahaan organda: menentukan harga seragam operator angkutan, 2) Penjualan produk peternakan tertentu seperti susu, 3) Asosiasi profesi misalnya asosiasi pengusaha tekstil yang membatasi pemain baru dalam pasar mereka.

Anggaplah bahwa hanya ada dua perusahaan yang menjual komoditi yang homogeny dan mereka memutuskan membagi pasar dengan merata. Jika D dalam Gambar 10.2.adalah kurva total permintaan untuk komoditi itu dan d adalah kurva setengah bagian pasar untuk masing-masing perusahaan dan MR adalah kurva penerimaan marginal yang sesuai. Dlasumsikan bahwa setiap perusahaan mempunyai SMC yang identik, maka masing-masing perusahaan akan menjual 200 unit.

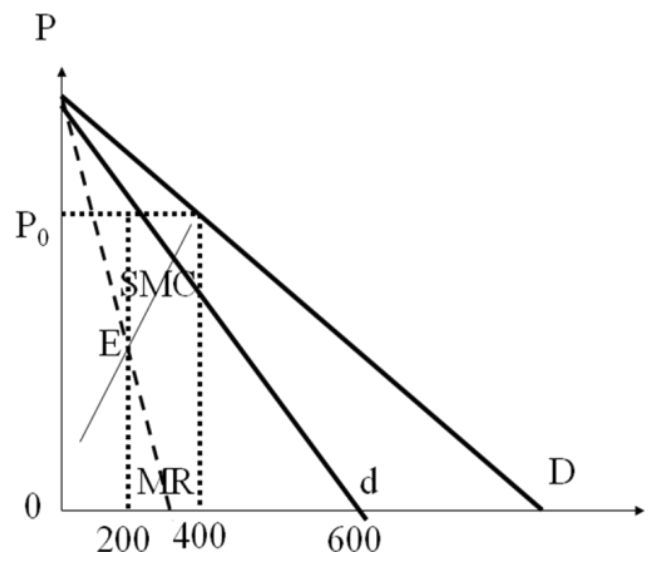

Gambar 10.2.Kesepakatan Kartel 


\subsection{Latihan Soal}

1. Jelaskan definisi dari oligopoli!

2. Apakah ciri dari pasar oligopoli?

3. Sebutkan implikasi dari ciri pasar oligopoli tersebut!

4. Apakah yang dicapai oleh teori oligopoly?

5. Asumsikan bahwa (1) hanya terdapat dua perusahaan A dan B yang menjual komoditi homogen dengan biaya produksi sebesar nol. (2) fungsi total permintaan pasar untuk komoditi ini dinyatakan oleh QD = 240 - 10P dan (3) Perusahaan A yang pertama memasuki pasar diikuti oleh perusahaan $B$, tetapi masing-masing selalu mengasumsikan dalam menentukan tingkat output terbaiknya bahwa yang lain akan mempertahankan output pada tingkat yang konstan.

Dengan mengacu pada apa yang dikemukan diatas:

(a) Perlihatkan dengan bantuan sebuah diagram bagaimana duopolies A dan $B$ menentukan titik equilibriumnya

(b) Berapa harga yang akan ditentukan masing-masing duopolis bila berada dalam kondisi equilibrium? Bagaimana bila dibandingkan dengan harga monopoli? Bagaimana dengan pasar persaingan sempurna?

(c) Berapa jumlah output yang akan diproduksi masing-masing duopolis bila berada dalam equilibrium? Bagaimana bila dibandingkan dengan harga monopoli? Bagaimana dengan pasar persaingan sempurna?

(d) Berapa keuntungan yang akan diperoleh masing-masing duopolis bila berada dalam kondisi equilibrium? Bagaimana bila dibandingkan dengan harga monopoli? Bagaimana dengan pasar persaingan sempurna?

(e) Apa yang akan terjadi terhadap output dan harga equilibrium industri ini jika lebih banyak perusahaan yang masuk?

\section{Istilah-istilah Penting;}

Interdependensi dalam oligopoli

Ketegaran harga dalam oligopoli

Kinked demand Curve

Collusion

Non price computition

Efek negatif dari oligopoli 


\section{BAB 11 \\ PASAR PERSAINGAN MONOPOLISTIS}

\section{TUJUAN INSTRUKSIONAL KHUSUS}

1. Mahasiswa dapat menjelaskan perilaku perusahaan di pasar persaingan monopolistis

2. Mahasiswa dapat mengukur keseimbangan pada pasar persaingan monopolistis

3. Mahasiswa dapat menjelaskan dampak dari implementasi pasar persaingan monopolistis.

4. Mahasiswa dapat menjelaskan kebaikan dan keburukan pasar persaingan monopolistis

\subsection{Karakteristik Persaingan Monopolistis}

Persaingan monopolistis terdapat bila dalam suatu pasar ada banyak produsen, tetapi ada unsur-unsur diferensiasi produk (perbedaan merek, bungkus dan sebaginya) diantara produk-produk yang dihasilkanya oleh masing-masing produsen. Dari segi kurve permintaan yang dihadapi oleh sebuah perusahaan, adanya diferensiasi produk berarti adanya kemapuan produsen (secara individual) untuk mempengaruhi (betapun kecilnya pengaruh tersebut) harga jual dari produknya. Tidak adanya homogenitas produk (jadi tidak adanya subsitusi yang sempurna antara hasil produk perusahaan " $A$ " dan hasil produk perusaghaan " $B$ " meskipun hasil tersebut sejenis) adalah aspek pokok yang membedakan pasar persaingan monopolistis dengan pasar persaingan sempurna, dan bukan aspek jumlah perusahaan yang ada di pasar, maupun aspek kebebasan bagi perusahaan-perusahaan baru untuk masuk kepada pasar).

Reynolds (2011) menyatakan karakteristik dari persaingan monopolistik adalah sebagai berikut:

a. Jumlah penjual sangat banyak sehingga tidak dapat mempengaruhi pasar

b. Adanya diferensiasi produk

c. Relatif mudah untuk masuk dan keluar pasar 
Perbedaan mendasar antara persaingan monopolistik dan persaingan sempurna adalah pada karakteristik dari outputnya. Pada persaingan monopolistik, terdapat diferensiasi produk. Terdapat banyak penjual yang artinya banyak barang substitusinya.

Hal ini menunjukkan bahwa permintaan individu dari perusahaan pada pasar persaingan monopolistik adalah lebih elastis dari pada pasar monopoli. Sedangkan nilai elastisitas tergantung pada preferensi dan perilaku dari konsumen. Kemiringan negatif dari kurva permintaan individu di pasar persaingan tidak sempurna mempunyai hasil yang berbeda dengan pasar persaingan sempurna.

Pada pasar persaingan monopolistis, hambatan masuk dan keluar pasar sangat kecil, Hal ini sama dengan karakteristik dari pasar persaingan sempurna dimana keluar dan masuk pasar relatif mudah. Hal ini berimplikasi dalam jangka panjang bahwa hasil yang diperoleh dari pasar persaingan tidak sempurna berbeda dengan pasar monopoli.

Gambar 11.1. menunjukkan maksimisasi keuntungan dari individu dalam jangka pendek. Hal ini terjadi pada output $Q_{\jmath}$ dimana $M R=M C$. Pada titik ini, average cost (AC) adalah $R$ dan biaya per unit adalah $C^{*}$. Total cost $(\mathrm{TC})$ adalah biaya per unit $\left(\mathrm{C}^{*}\right)$ dikalikan dengan tingkat output $Q_{\jmath}$ atau area $0 Q_{\lrcorner} R C^{*}$.

Perusahaan bias menjual $Q_{\jmath}$ unit pada tingkat harga $P^{*}$. Total Revenue (TR) adalah $P^{*}$ dikali dengan tingkat output $\left(Q_{J}\right)$ atau area $0 Q_{\lrcorner} H P^{*}$. Jadi, total profit ditunjukkan pada area $C^{*} R H P^{*}$ atau $\left(P^{*}-C^{*}\right) Q_{J}$ (area yang diarsir).

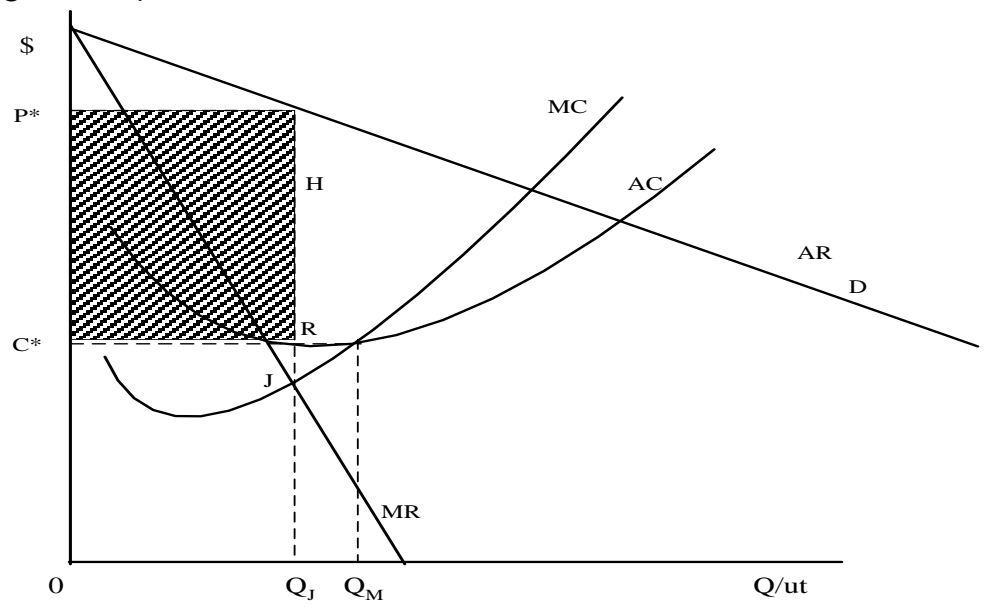

Gambar 11.1. Maksimisasi Keuntungan Jangka Pendek pada Pasar Persaingan Monopolistis 


\subsection{Keseimbangan dalam Persaingan Monopolistis}

Bentuk kurve permintaan yang dihadapi oleh sebuah perusahaan persaingan monopolistis adalah menurun. Posisi equilibrium (keseimbangan) dari perusahaan persaingan monopolistis adalah, seperti biaya, di mana MR=MC. Tetapi karena adanya kebebasan bagi perusahaan yang telah ada di pasar memperoleh keuntungan yang cukup besar sehingga bisa menarik investor baru ini, maka dalam jangka panjang equilibrium akan tercapai pada posisi dimana kurva permintaan (D) bersinggungan dengan kurva AVC. Pada posisi ini tidak ada keuntungan lebih; perusahaan hanya menerima keuntungan "normal" seperti yang diterima perusahaan-perusahaan di pasar lain.

Masuknya perusahaan-perusahaan baru akan menciutkan "pasar" dari masing-masing produsen karena luas pasar yang sama sekarang harus dibagi diantara lebih banyak produsen. Kemungkinan efek lain dari masuknya perusahaan-perusahaan baru adalah naiknya harga-harga input yang dipergunakan, yang berakibat bergesernya $A C$ ke atas. Bila excess profit telah lenyap (bila $D=A C$ ) maka proses masuknya perusahaan-perusahaan baru berhenti, dan equlilibrium tercapai.

\subsection{Dampak Persaingan Monopolistis}

Efek dari pasar persaingan monopolistis adalah dapat disebutkan sebagai berikut:

1. Ketidak efisienan produksi karena produsen-produsen tidak berproduksi dengan AC yang minimum. Ini adalah konsekuensi dari adanya kurva permintaan yang menurun. AC minimum tidak tercapai berarti bahwa perusahaan-perusahaan tidak memanfaatkan secara penuh economies of scale yang tersedia. Dengan perkataan lain, di dalam pasar tersebut terlalu banyak perusahaan-perusahaan yang ukurannya terlalu kecil. Ini adalah pemborosan sumber-sumber ekonomi maysrakat.

2. Konsumen masih harus membayar harga produk yang lebih tinggi dari ongkos marginal untuk menghasilkan produk tersebut. Sebaliknya input dibayar hanya setinggi MC, yang lebih rendah dari pada nilai output marginal yang dihasilkan oleh faktor-faktor produksi tersebut yang tidak lain adalah harga jual $(P)$ output tersebut. Sekali lagi masalahnya bersumber pada $\mathrm{P}>\mathrm{MC}$. 
Mengenai efek negatif (1) di atas ada argumentasi (dari prof. Chamberlain) yang mengatakan bahwa sebetulnya tidak beroprasinya perusahaan-perusahaan persaingan monopolistis pada posisi AC minimum bukan merupakan pemborosan sumber eknonomi yang sia-sia. Sebabnya adalah bahwa masyarakat menerima imbalan dari "ketidakefisienan" penggunaan sumber-sumber ekonomi ini berupa tersedianya Varitas-varitas produk yang bisa dipilih oleh para konsumen. Kalau setiap barang di dunia ini homogen (seragam) tentunya dunia ini adalah tempat yang paling membosankan. Tersedianya keanekaragaman barang-barang di pasar itu sendiri memberikan kepusan tambahan kepada para konsumen. Jadi sumber-sumber ekonomi yang hilang tadi tidaklah sia-sia.

\subsection{Latihan Soal}

1. a. Definisikan pasar persaingan monopolistis dan berikan contohnya!

b. Tunjukkan ciri-ciri dari persaingan monopolistis!

c. Mengapa sangat sulit dalam mendefinisikan dan menjelaskankan industri jenis ini?

2. Sebutkan dampak dari persaingan monopolistis!

3. a. Gambarkan fungsi permintaan $Q D=32-P$ dan skedul permintaan (tabel dibawah ini) yang menghadapi perusahaan yang bersaing secara monopolistis!

b. Jelaskan arti dari masing-masing kurva permintaan ini

\begin{tabular}{|c|l|l|l|l|}
\hline $\mathrm{P}$ & 26 & 24 & 22 & 20 \\
\hline $\mathrm{QD}$ & & & & \\
\hline
\end{tabular}

\section{Istilah-istilah Penting;}

Persaingan monopolistis

Diferensiasi produk 


\section{DAFTAR PUSTAKA}

Ari Sudarman, 1988, Teori Ekonomi Mikro, BPFE, UGM, Yogyakarta.

Anonymous, 2008, Ekonomi Mikro, Universitas Pembangunan Nasional Veteran Jatim, Surabaya.

Bilas, Richard A, 1971, Microeconomic Theory, McGrwa-Hill Kogakusha, Tokyo.

Boediono, 1982, Seri Sinopsis Ekonomi Mikro, BPFE, UGM Yogyakarta.

Domonic, Salvatore, 1987, Theory and Problems of Microeconomic Theory, 2 th Edition, McGraw-Hill, Singgapore.

Endang Sulistiyowati dkk, 2000, Ekonomi Mikro Pengantar, AMP YKPN, Yogyakarta.

Iswardono, 1990, Ekonomika Mikro, AMP YKPN, Yogyakarta.

Lipsey, R. G and Paul N. Courant, 1996, Economics, Hiper Collins College, Publishers, 11 th Edition, United Kingdom.

Nicholson, Walter, 1992, Microeconomic Theory, Basic Principles and Extention, 5 th Edition, Dryden Press, Fort Wort, Texas.

Reynolds, R. L, 2011, Basic Microeconomic. Text Book Equity. Boise State University.

Salvatore, D. 2011.Schaum's Outline of Microeconomic Theory, Fourth Edition. McGraw-Hill.

Samuelson and Nordhaus, 1998, Economic, McGraw-Hill, Inc.

Suparmoko, M, 1997, Pengantar Ekonomika Mikro, Edisi 3, BPFE, Yogyakarta. 